\title{
Resumos de Dissertações de Mestrado e Teses de Doutorado apresentadas na Faculdade de Medicina de Ribeirão Preto - USP de outubro a dezembro de 2010
}

\section{Biologia Celular e Molecular}

\author{
AVALIAÇÃO PROTEÔMICA DO EFEITO DE INIBIDORES DE PROTEÓLISE NA \\ DEGENERAÇÃO MUSCULAR DE CAMUNDONGOS DISTRÓFICOS $\mathbf{m d x}$
}

\author{
Ana Carolina Humanes \\ Orientador: Prof. Dr. Lewis Joel Greene \\ Dissertação de Mestrado apresentada em 26/10/2010
}

\begin{abstract}
A Distrofia Muscular de Duchenoe (DMD) é uma doença fatal-caracterizada por degenaração muscular progressiva. O camundongo $m d x$, modelo mais utilizado da DMD, apresenta uma mutação que cria um códon de parada no exon 23 do gene da distrofina, resultando na produção de uma proteína truncada que é degradada. A ausência dá distrofina causa distúrbio na homeostase do cálcio e a consequente ativação de calpaínas, proteases dependentes de cálcio, o que contribui para a degeneração das miofibras. 0 sistema ubiquitina-proteassomo também está envolvido no aumento da proteólise na fisiopatologia da DMD. O objetivo deste estudo foi avaliar o efeito dos tratamentos com dois inibidores de proteólise na degeneração muscular e no perfil proteico do músculos esqueléticos de camundongos $m d x$. A avaliação quantitativa in vitro utilizando másculos isolados mostrou que as taxas de proteólise total e pelo sistema ubquitina-proteassomo foram significativamente maiores no músculo sóleo de camundongos $m d x$ em relação a camundongos C57 normais (36\% e 61\%, respectivamente). Camundongos $m d x$ machos de 19 dias foram tratados subcutaneamente durante 10 dias com $10 \mathrm{mg} / \mathrm{kg}$ de MDL28170, com $10 \mu \mathrm{g} / \mathrm{kg}$ de MG-132 ou com os respectivos veículos. Os ensaios de imunohistoquímica mostraram que em camundongos submetidos aos dois tratamentos houve detecção da distrofina no sarcolema do gastrocnêmio (GA) e dó diagrama (DIA), mas não em animais tratados com os veículos. Além disso, a beta-distroglicana ( $\beta D G)$, uma proteína associada a distrofina, foi detectada no sarcolema dos dois músculos de $m d x$ tratados com os dois inibidores de proteólise ou com os veículos. Por meio de Western blot semi-quantitativo demonstrou-se que os níveis de $\beta D G$ no GA e no DLA foram simitares entre $m d x$ tratados com os inibidores de proteólise ou com as veículos. Os ensaios de azul de Evans demonstram que no GA e no DIA de $m d x$ tratados com MG-132 houve significativa redução da porcentagem de miofibras lesionadas em relação aos tratados com veículo, o que não ocorreu com o tratamento com MDL28170. O ensaio proteômico 2D-DIGE permitiu detectar 39 spots diferencialmente acumulados ou diminuídos no GA de $m d x$ tratados com MDL28170 comparados ao veículo e 29 spots entre $m d x$ tratados com MG-132 comparados ao veículo. Dentre as proteínas identificadas por MALDITOF-TOF, duas isoformas da MG53, uma proteína relacionada ao reparo de membrana, estavam alteradas nos $m d x$ tratados com MG-132 (uma isoforma aumentada e outra diminída) e uma isoforma estava aumentada nos $m d x$ tratados com MDL28170. Além disso, identificamos quatro proteínas do metabolismo energético, que é deficiente em $m d x$, alteradas nos animais tratados com MG-132. Os resultados indicam que os inibidores de proteólise foram efetivos para a correta localização da sitrofina na sarcolema e podem ser importantes no mecanismo de reparo da membrana celular. Além disso, a ativação do sistema ubiquitina-proteassomo pode estar envolvida na degeneração muscular e no metabolismo energético de camundongos $m d x$.
\end{abstract}

\section{IDENTIFICAÇÃO DE UM NOVO GENE PRÓ PROLIFERATIVO ASSOCIADO COM A PROGRESSÃO DO MELANOMA E A MUTAÇÃO ATIVADORA DE BRAF}

Cristiano Gonçalves Pereira

Orientadora: Profa. Dra. Enilza Maria Espreafico

Dissertação de Mestrado apresentada em 03/11/2010

A identificação e caracterização de novos genes com expressão tumor-específica é uma ferramenta potencialmente útil para o desenvolvimento de novas estratégias de diagnóstico e terapia do câncer. Utilizando ferramentas de bioinformática 
desenvolvidas localmente para mineração de bancos de dados de ESTs, nosso grupo identificou 29 clusters UniGene de múltiplas ESTs provenientes exclusivamente de fontes de melanoma, e validou experimentalmente a expressão específica em melanoma para três destes genes, sem potencial codificador segundo programas de predição. No presente trabalho, buscou-se estender a análise de validação para um grupo de genes da mesma lista com potencial codificador e também sem qualquer caracterização funcional prévia. Dos genes inicialmente propostos para análise neste trabalho, BC019009 (HTA), Similar to hypothetical protein (L1H3), sinovial sarcoma (SSX-5)Carbonic anhydrase XIV (CA14), $\beta$-Tubulina $4 Q$ (TUBB4Q), Zinc finger protein 705D e 705A (ZNF705D, ZNF705A), não foi possível detectar a presença de mRNA para os quatro últimos em amostras de cDNA de um grupo de linhagens de melanoma, por qRT-PCR. Demonstramos que HTA (Hs.382776) e L1H3 (Hs.617329) apresentam expressão bastante enriquecida em células de melanoma, ainda que detectada também em outros poucos tecidos. L1H3 mostrou expressão variável entre amostras de nevos, melanoma primário e mestastático, sem diferenças significativas entre os grupos. HTA apresentou baixa expressão em melanócitos normais e nevos, e ganho de expressão em 45\% das amostras de tumor primário e 70\% das metástases, mostrando correlação positiva com a progressão do melanoma e com a ocorrência da mutação oncogênica de BRAF V600E. Sendo assim, elegemos este gene para posteriores análises funcionais. O gene HTA encontra-se na região cromossômica 16q22.3, contém três exons e ORFs de 92a iniciada com códon AUG e uma ORF de 139aa iniciada com UUG. A ORF considerada mais provável segundo análises do potencial codificador e relatório do GenBank é a de 279 pb, da qual se deduz uma sequência protéica de 92 resíduos de aminoácidos. O fragmento correspondente à ORF279 foi clonado para expressão em células de mamífero e bactéria. A proteína em fusão com EGFP(HTA-EGFP), expressa em células de melanoma, assim como em outros tipos celulares, localiza-se fortemente no núcleo e apresenta massa molecular aparente condizente com a massa calculada (12 kDa). A proteína em fusão com GST (GST-HTA) foi expressa em bactéria e purificada para produção de anticorpos e uso como antígeno na busca por anticorpos circulantes em paciente com melanoma em trabalhos futuros. O silenciamento do gene HTA por siRNA, em células de melanoma metastáticas (linhagem WM1617) que naturalmente superexpressam este gene, não afetou a capacidade de migração celular, mas causou redução significativa na taxa de proliferação sob condições normais de adesão e também no crescimento independente de ancoragem (formação de colônia em agar). Os dados obtidos sugerem fortemente que a ativação do gene HTA esteja associada com a mutação ativadora de BRAF e exerça um papel promotor da progressão do melanoma. Concluindo, o trabalho abre perspectivas para futuros investimentos em direção à ampla caracterização do gene HTA, buscando definir a real relevância do gene na progressão do melanoma e sua utilidade como marcador prognóstico ou alvo terapêutico.

\section{ASF1 (ANTI SILENCING FACTOR 1) DE LEISHMANIA MAJOR}

\section{Juliana Bório Ferreira Garcia}

Orientadora: Profa. Dra. Angela Kaysel Cruz

Dissertação de Mestrado apresentada em 05/11/2010

Os mecanismos e os genes envolvidos na remodelagem da cromatina em tripanossomatídeos têm sido objeto de intensa investigação nos últimos anos. Envolvida nesse processo e caracterizada em diferentes organismos, a ASF1 (AntiSilencing Factor 1) foi identificada como uma chaperona de histonas que contribui para a deposição destas durante a montagem dos nucleossomos em DNA recém-replicado. Esta proteína também está envolvida na resposta celular a danos ao DNA e silenciamento transcricional. Identificamos em nosso laboratório uma ASF1-símile em Leishmania major e estudos funcionais indicam que também nos tripanossomatídeos a ASF1 está envolvida no empacotamento da cromatina e na preservação da integridade do DNA. Na tentativa de avaliar o envolvimento de ASF1 no controle da expressão gênica em L. major fizemos uma análise comparativa entre os proteomas de promastigotas de linhagem superexpressora de ASF1, $L m[p X N e o-A S F 1]$, e de linhagem controle, $L m[p X N e o]$. As diferenças no perfil protéico foram analisadas por eletroforese em géis bidimensionais e 19 proteínas diferencialmente expressas foram identificadas por espectrometria de massa. Como a ASF1 de Saccharomyces cerevisiae controla expressão de genes presentes nas regiões teloméricas dos cromossomos, investigamos ação semelhante da LmASF1 sobre genes de extremidade cromossômica de $L$. major por ensaios de PCR em Tempo Real. Nossos resultados sugerem que LmASF1 não modifica a expressão desses genes. Além disso, com o objetivo de avaliar o papel LmASF1 em processos de reparo de DNA, submetemos Lm[pXNeo-ASF1] e Lm[pXNeo] a diferentes agentes genotóxicos que desencadeiam vias de reparo de DNA distintas. Nossos resultados sugerem que a superexpressão de ASF1 contribui significativamente para a resistência das células ao estresse oxidativo, uma vez que Lm[pXNeo-ASF1] é mais resistente a danos causados pelo peróxido de hidrogênio $\left(\mathrm{H}_{2} \mathrm{O}_{2}\right)$. Submetido à irradiação gama, o transfectante que superexpressa LmASF1 recupera-se mais lentamente do que a linhagem controle e nossos dados permitem especular que LmASF1 nesse caso atue sobre o controle do ciclo celular. Portanto, os dados obtidos indicam que LmASF1 tem funções múltiplas e parece atuar sobre o controle do ciclo celular e processos de reparo do DNA em Leishmania. 


\title{
ESTUDO DA REGULAÇÃO TRANSCRICIONAL DO LOCUS ROUGHEST DE Drosophila melanogaster E CARACTERIZAÇÃO MOLECULAR DAS REVERSÕES DE SEU ALELO roughest dominant (RST ${ }^{\mathrm{I}}$ )
}

\author{
Maiaro Cabral Rosa Machado \\ Orientador: Prof. Dr. Ricardo Guelerman Pinheiro Ramos \\ Dissertação de Mestrado apresentada em 08/11/2010
}

A organização das células em uma configuração espacial especifica requer adesões celulares seletivas. Durante o desenvolvimento da retina de Drosophila melanogaster as omatídias vizinhas são separadas pelas células interomatidiais (IOCs). A reorganização das IOCs em uma única camada, etapa essencial para a eliminação das células em excesso que permite a emergência do arranjo omatidial extremamente preciso do olho composto adulto, é regulada pela adesão preferencial entre esta e as células pigmentares primarias mediadas pelas proteínas Hibris (Hbs) e Roughest (Rst) através de interações heterofilicas (Bao e Cagan, 2005). Defeitos neste processo resultam em olhos com aparência "rugosa" devido à presença de um maior número de células que desorganizam a estrutura hexagonal extremamente regular das omatídias. Rst é uma proteína transmembranar unipasso da superfamília das imunoglobulinas de Drosophila e membro prototípico do Módulo de Reconhecimento Celular (Irre Cell Recognition Module - IRM), um pequeno grupo de proteínas da superfamília das Imunoglobulinas que incluem também kirre e sns, parálogos de rst e hibris respectivamente, que funcionam em conjunto, frequentemente de maneira funcionalmente redundante, em diversas interações celulares durante o desenvolvimento embrionário e pós-embrionário e apresentam ortólogos desde C. elegans até humanos (Fischbach et al., 2009). Importantes informações sobre as funções do gene roughest $(r s t)$ foram obtidas através de estudos de um alelo regulatório semidominante de $r s t$ denominado $r s t^{D}$, cuja mutação está associada a um rearranjo genômico localizado aproximadamente 18-19 kb a montante do putativo sitio de inicio de transcrição do lócus. Este mutante apresenta um atraso na onda de morte celular programada, disparada pela redistribuição intracelular fisiológica de Rst nas IOCs (Araujo et al, 2003). Um dos comportamentos fenotípicos mais intrigantes deste alelo é a capacidade de reverter o seu fenótipo de olho "rugoso" original para indivíduos com fenótipo de olhos aparentemente normais. A caracterização prévia dos revertantes mostrou que eles têm comportamento genético e molecular diferente. Neste trabalho foi inicialmente realizada uma análise temporal comparativa dos níveis de mRNA dos lóci rst e kirre, por meio de RT-PCR quantitativo, durante o desenvolvimento do olho composto em indivíduos selvagens $(C S)$, no mutante regulatório $r s t^{D}$ e em seus revertantes $(R W T x)$ com olho selvagem. Em retinas $C S$ e $r s t^{D}$, a expressão $r s t$ aumenta rapidamente atingindo seu pico durante a fase de "cell sorting", quando cai de forma rápida apenas em $C S$, passando pela fase de morte celular programada com níveis mais baixos. Surpreendentemente, apesar dos RWTXs apresentarem olho selvagem, não existe um resgate da expressão selvagem de mRNA rst. A expressão de mRNA kirre nos RWTXs com olho selvagem varia inversamente à queda da expressão de mRNA rst em cada fase. O aumento de mRNA kirre é visto também em experimentos de silenciamento gênico de rst por RNAi no olho composto. Estes resultados demonstram pela primeira vez uma evidência direta de corregulação entre rst e kirre no olho composto, sugerindo uma redundância regulada pós-transcricionalmente. Além disso, foi realizado o perfil de expressão de $r s t$ na glândula salivar larval selvagem, que demonstrou um aumento expressivo dos níveis de mRNA rst selvagem após o segundo pico do hormônio ecdisona, 10 horas após a formação do pupário (AFP), atingindo seu pico em 12 horas APF, seguido de uma rápida diminuição em seus níveis em 13 horas AFP. Entretanto, no mutante $r t^{D}{ }^{D}$, os níveis de mRNA em 13 horas APF estão aumentados em relação aos os níveis selvagens e não foi visto, no revertante selvagem $R W T 6$, nenhuma alteração no padrão de expressão em relação ao selvagem, apesar de permanecerem sempre abaixo. Os níveis de mRNA de kirre na glândula salivar larval selvagem aumentam rapidamente somente após a queda dos níveis de mRNA de roughest, assim como o que foi visto para os níveis de mRNA de kirre na retina em desenvolvimento. Juntos, estes resultados, contribuem para um entendimento mais abrangente dos mecanismos relacionados com a regulação dos genes roughest e kirre durante o desenvolvimento de Drosophila.

\section{AVALIAÇÃO DA LEVEDURA Saccharomyces cerevisiae COMO VEÍCULO VACINAL CONTRA A PARACOCCIDIOIDOMICOSE}

\author{
Mariana Aprigio Assis \\ Orientador: Prof. Dr. Paulo Sergio Rodrigues Coelho \\ Dissertação de Mestrado apresentada em 03/12/2010
}

A paracoccidioidomicose (PCM) é uma infecção fúngica endêmica na América Latina cujo agente causal é o fungo termodimórfico Paracoccidioides brasiliensis. O antígeno dominante da PCM é denominado gp43 que induz resposta imune protetora em camundongos vacinados. Apesar dos esforços recentes no estudo de antígenos vacinais para o tratamento e/ou prevenção dessa importante micose, urge o desenvolvimento de novas estratégias. Neste sentido utiliza- 
mos a levedura Saccharomyces cerevisiae como veículo vacinal contra a PCM. A vantagem desta levedura consiste no fato de que é um organismo não patogênico, facilmente manipulável geneticamente e com propriedades adjuvantes intrínsecas (beta-glucana da parede celular). Com o objetivo de avaliar a capacidade da levedura recombinante que expressa a gp43 em conferir proteção contra essa micose, cDNA da Gp43 foi clonado em vetores de expressão de $S$. cerevisiae. Após a indução da expressão com a adição de galactose ao meio de cultura, pudemos detectar a superexpressão de gp43 com anticorpo monoclonal anti-gp3 ou anti-HA em ensaios de Western blotting. A levedura recombinante que expressa a gp43 foi administrada profilaticamente via intraperitoneal em camundongos BALB/c que foram infectados endovenosamente com levedura de $P$. brasiliensis. Utilizamos dois grupos controle (1) camundongos inoculados com a levedura com o plasmídeo que não expressa a gp43, e (2) camundongos inoculados com PBS. Os camundongos foram mantidos por 30 dias para que a infecção se estabelecesse e, após este período, os animais foram sacrificados e os órgãos coletados (pulmão, baço e fígado). A capacidade de infecção do fungo foi avaliada pela contagem das unidades formadoras de colônias (UFC) por grama de tecido dos órgãos de cada um dos animais vacinados e posteriormente infectados. Pulmões, baços e fígados dos grupos de camundongos inoculados com leveduras expressando ou não a gp43, apresentaram níveis reduzidos de unidades formadoras de colônias comparados com o grupo inoculado com PBS, o que indica um papel protetor de S. cerevisiae em infecção experimental. Os ensaios histológicos foram realizados para verificação do aspecto do tecido pulmonar no que se refere a manutenção dos septos alveolares e quantidade de granulomas formados. O pulmão dos camundongos do grupo vacina mostrou-se praticamente inalterado com pouca quantidade de granulomas. Análises de quantificação de citocinas foram realizadas. Camundongos do grupo vacina, que expressa gp43, produziram altos níveis de IL-12 e IFN- $\gamma$ e níveis reduzidos de IL-4 e IL-10. O conjunto de resultados indica que a vacina é capaz de elicitar uma resposta protetora do tipo Th1 contra a PCM.

\title{
ANÁLISE DA TRANSCRIÇÃO DE GENES CANDIDATOS RELACIONADOS À DIFERENCIAÇÃO DE CASTAS EM Apis mellifera
}

\author{
Mipsi Cristina Mori \\ Orientador: Prof. Dr. Klaus Hartmann Hartfelder \\ Dissertação de Mestrado apresentada em 10/12/2010
}

Entre os insetos sociais, as abelhas melíferas são as espécies mais bem estudadas no que diz respeito à diferenciação de castas e à divisão de trabalho. A diferenciação de castas é induzida pela alimentação diferencial das larvas com maior quantidade de geléia real, que desencadeia uma cascata de reações endógenas entre as quais os níveis de hormônio juvenil têm um papel central. Supõe-se que durante a fase larval, este hormônio, em conjunto com ecdisteróides, tem influência sobre a expressão gênica originando diferentes fenótipos alternativos no sexo feminino, as rainhas e as operarias. Através do sequenciamento do genoma de Apis mellifera, foi possível identificar e anotar genes associados ao processo de diferenciação das castas. Notavelmente, dois grupos funcionais, foram encontrados em conjuntos de ESTs (Expressed Sequence Tags), genes associados com a regulação do metabolismo e genes envolvidos em processos de desenvolvimento. Destes genes, os seis mais divergentes em termos de níveis de expressão em uma determinada fase do desenvolvimento de operária e rainha, e com um maior número de motivos potencialmente regulados nas suas regiões a montante (5'UCR), foram estudados neste trabalho. Para tanto o resultado do nível de expressão desses genes relacionados à diferenciação de castas foram obtidas através de RT-PCR quantitativa. Observou-se que tais genes expressam-se diferencialmente entre rainhas e operarias nas três fases estudadas (L3, L4 e L5F2), sendo significativamente mais expressos na fase L4 em operarias para os genes GB10428, GB19006 e sesB e, na fase L5F2 para o gene $m g s t l$. Quando se realizou a aplicação tópica de hormônio juvenil, os níveis de expressão aumentaram em condições laboratoriais no quarto instar larval para os genes mgstl, GB10428, GB19006 e sesB em comparação a rainha. Os dados deste trabalho aprofundarão o conhecimento sobre a determinação de castas em abelhas melíferas relacionado à regulação da expressão gênica.

\section{ANÁLISE PROTEÔMICA DAS DIVERSAS FASES DE DIFERENCIAÇÃO OSTEOBLÁSTICA DE CÉLULAS-TRONCO MESENQUIMAIS DE MEDULA ÓSSEA}

\section{Leonardo Barcelos de Paula}

Orientador: Prof. Dr. José César Rosa

Dissertação de Mestrado apresentada em 13/12/2010

O crescimento, desenvolvimento e manutenção do tecido ósseo são processos altamente regulados. Diversas proteínas como hormônios, fatores de crescimento e citocinas estão envolvidas nestes processos e exercem atividade 
direta sobre células osteoblástica e osteoclástica, atuando em sua diferenciação e ativação metabólica. O processo de regeneração óssea é iniciado por fatores estimuladores locais como as proteínas morfogenética óssea (BMP - Bone Morphogenetic Proteins). As BMPs são um produto do metabolismo dos osteoblastos, odontoblastos e de várias células tumorais, sendo armazenadas na forma de concentrados no osso, dentina e em células neoplásicas do osteossarcoma e de certos tumores odontogênicos, tais como: fibroma cementificante, cementoblastoma benigno, dentinoma, fibroma odontogênico e odontoma. Esclarecer os mecanismos que controlam a remodelação óssea é uma questão bastante relevante. Nesse sentido, as células-tronco mesenquimais têm despertado grande interesse devido ao seu potencial envolvimento no processo de reparo tissular. A obtenção de osteoblastos funcionais a partir de células-tronco mesenquimais tem sido utilizada na engenharia de tecidos e terapia celular. Desse modo, no presente trabalho foi realizada uma análise proteômica das proteínas envolvidas nas diversas fases de diferenciação osteoblástica de células-tronco mesenquimais de medula óssea de rato Wistar e humana, no sentido de obter maiores informações sobre a diferenciação celular e a biologia do tecido ósseo. Células-tronco mesenquimais obtidas de medula óssea foram cultivadas em meio osteogênico por diferentes períodos para obter células em diversas fases da diferenciação osteoblástica. Para análise proteômica foram utilizadas ferramentas como a estratégia de shotgun proteomics e quantificação relativa (iTRAQ - Isobaric Tag for Relative and Absolute Quantitation) para separação de proteínas e a espectrometria de massas para a identificação e quantificação relativa de proteínas e peptídeos. Neste contexto, os nossos resultados nos levam a concluir que: as CTMs de medula óssea de rato Wistar expressam genes que estão envolvidos na diferenciação osteogênica quando estimuladas in vitro formando matriz óssea no período de 14 dias, ou seja, o fator estimulante no microambiente é de fundamental importância; as CTMs de medula óssea humana apresentaram resultados semelhantes com as CTMs de ratos em nível genômico durante a diferenciação osteogênica, entretanto quando estimuladas in vitro formaram a matriz óssea no período de 21 dias; utilizando duas abordagens proteômicas, foi possível identificar proteínas importantes que estão envolvidas no processo de diferenciação. Mas cabe salientar que, embora tenham sido detectados genes que parecem envolvidos no processo de diferenciação, isso não teve reflexo no proteoma dessas células nos períodos de 7 e 14 dias da indução de diferenciação à osteogênese, o que indica que a maior parte da funcionalidade dessas células quanto aos outros processos biológicos estão preservados, como por exemplo a proliferação celular permaneceu sem grandes alterações. Isso indica que manipulações de isolamento, cultivo e indução da diferenciação dessas células não afetaram o proteoma, com aspectos positivos para a utilização de células-tronco mesenquimais em terapia celular. Do ponto de vista metodológico, esse trabalho abre perspectivas da utilização de estratégias proteômicas baseadas na marcação por isóbaros em combinação com separação de proteínas por eletroforese unidimensional SDS-PAGE para a análise de amostras biologicamente complexas e de quantidades limitadas de obtenção como células-tronco mesenquimais. O estudo da expressão de proteínas durante as fases de diferenciação osteoblástica de células-tronco mesenquimais de medula óssea deve refletir seu estado funcional e contribuir para o entendimento das diversas vias envolvidas no processo de diferenciação.

\section{Clínica Cirúrgica}

\section{EFEITO DE DIFERENTES FLUÊNCIAS DO LASER DE DIODO 830NM NA VIABILIDADE DO RETALHO CUTÂNEO RANDÔMICO EM RATOS}

\section{Tiago de Souza Ribeiro}

Orientador: Prof. Dr. José Antonio Thomazini

Tese de Doutorado apresentada em 22/10/2010

Na cirurgia plástica estética e reparadora, um dos recursos mais usado são os retalhos cutâneos, porém estes retalhos podem frequentemente desenvolver necrose e perda do retalho, em função do processo isquêmico que neles instalam. Na tentativa de aumentar a sobrevida destes retalhos, pesquisas vem sendo realizadas usando alternativas não farmacológicas, como por exemplo a laserterapia de baixa intensidade, cujos benefícios vem sendo cada vez mais descritos na literatura científica. O objetivo deste estudo é verificar a fluência mais eficiente para o aumento da viabilidade destes retalhos cutâneos. Foram utilizados 40 ratos albinos da linhagem Wistar, distribuídos em quatro grupos de 10 animais cada: Grupo 1 (controle). Animais submetidos à técnica operatória para obtenção de um retalho cutâneo de base cranial, que sofreram a simulação de irradiação de laser diodo para verificar se há interferência do transdutor; os demais grupos foram 
similares ao grupo 1 (controle), mas com a aplicação do laser com as correspondentes fluências em cada grupo. Grupo $2\left(4 \mathrm{~J} / \mathrm{cm}^{2}\right)$; Grupo $3\left(16 \mathrm{~J} / \mathrm{cm}^{2}\right)$; Grupo $4\left(40 \mathrm{~J} / \mathrm{cm}^{2}\right)$. As aplicações foram realizadas imediatamente no pós -operatório e nos quatro dias subsequentes. Após a eutanásia dos animais as áreas de necrose e viável foram examinadas e avaliadas através de dois métodos morfométricos, um manual (pesagem de um gabarito de papel) e outro semiautomático (MiniMop $\left.{ }^{\circledR}\right)$. Além destas aferições foram também contabilizados os vasos sanguíneos pérvios em uma área pré determinada do retalho. Os resultados foram submetidos à análise estatística através do teste ANOVA e a pós testes (Método dos Contrastes Ortogonais). No método manual, os valores de área de necrose obtidos para o Grupo 1 (controle) variaram entre $39,63 \%$ e 58,97\%, com média de 46,86\%; para o Grupo $2\left(4 \mathrm{j} / \mathrm{cm}^{2}\right)$ entre $31,85 \%$ e 39,05\%, com média de 34,90\%; para o Grupo $3\left(16 \mathrm{j} / \mathrm{cm}^{2}\right)$, entre $24,81 \%$ e $31,48 \%$, com média de $28,01 \%$ e para o grupo $4\left(40 \mathrm{j} / \mathrm{cm}^{2}\right)$ entre $14,23 \%$ e $24,38 \%$ com média de 20,03\%. Em relação ao método semiautomático os valores obtidos para a área de necrose no Grupo 1 (controle) variaram entre 38,56\% e 57,03\%, com média de 46,02\%; para o Grupo $2\left(4 \mathrm{j} / \mathrm{cm}^{2}\right)$ entre 30,08\% e 37,09\%, com média de 33,55\%; para o Grupo $3\left(16 \mathrm{j} / \mathrm{cm}^{2}\right)$, entre $24,05 \%$ e $30,68 \%$, com média de $27,08 \%$; e para o grupo $4\left(40 \mathrm{j} / \mathrm{cm}^{2}\right)$, entre $14,05 \%$ e $23,70 \% \mathrm{com}$ média de $19,21 \%$. Neste estudo os valores da contagem de vasos sanguíneos pérvios no grupo 1 (controle) variaram entre 25 e 38 vasos, com média de 32 vasos; para o grupo $2\left(4 \mathrm{~J} / \mathrm{cm}^{2}\right)$ entre 36 e 57 vasos, com média de 45 vasos; para o grupo $3\left(16 \mathrm{~J} / \mathrm{cm}^{2}\right)$ entre 44 e 70 vasos com média de 52,8 vasos e para o grupo $4\left(40 \mathrm{~J} / \mathrm{cm}^{2}\right)$ entre 55 e 70 vasos, com média de 64,1 vasos. Os resultados obtidos neste estudo com os parâmetros utilizados permitem afirmar principalmente que:

- O laser de baixa intensidade $(\lambda=830 \mathrm{~nm})$ foi eficaz no aumento da viabilidade do retalho cutâneo randômico em ratos, em todas as fluências utilizadas neste estudo.

-A fluência de $40 \mathrm{~J} / \mathrm{cm} 2$ foi a mais eficaz no aumento da viabilidade do retalho cutâneo randômico em ratos, quando comparada às outras fluências testadas.

- A laserterapia utilizada, efetivamente diminuiu as áreas de necrose nos retalhos cutâneos para valores absolutos menores que os obtidos para os animais controles e para valores estatísticos menores que os valores obtidos para os animais irradiados, aumentando significativamente o número de vasos sanguíneos pérvios presentes na área viável, contrapondo-se aos efeitos deletérios do processo isquêmico neste tipo de procedimento e assim melhorando as condições de viabilidade destes retalhos.

- Foi observada uma grande correlação estatística entre os métodos macroscópicos de análise empregados, embora o método semiautomático tenha produzido valores absolutos mais homogêneos e precisos.

\title{
ANALISE ULTRAESTRUTURAL DA COMISSURA ANTERIOR DE RATOS ALBINOS WISTAR SUBMETIDOS A HIDROCEFALIA EXPERIMENTAL
}

\author{
Kleber Tadeu Carraro \\ Orientadora: Profa. Dra. Luiza da Silva Lopes \\ Tese de Doutorado apresentada em 27/10/2010
}

A hidrocefalia e uma das mais comuns alterações neurológicas da infância, causada pelo comprometimento na circulação ou na absorção do liquido cefaloespinhal (LCE) e geralmente caracterizada pela dilatação dos ventrículos cerebrais. A patofisiologia da hidrocefalia e multifatorial e esta associada à destruição da substancia branca periventricular resultante de uma combinação de mecanismos, como compressão e estiramento tecidual, acumulo de produtos tóxicos do metabolismo celular no LCE e comprometimento do fluxo sanguíneo. A troca de informacões entre os hemisferios cerebrais dos mamiferos depende das fibras comissurais. Neurônios projetados para áreas especificas do cérebro conectam-se reciprocamente através de três principais sistemas comissurais: corpo caloso, comissura hipocampal e comissura anterior. O presente estudo tem por objetivos avaliar as alterações ultraestruturais das células gliais (astrocitos e oligodendrocitos) e das fibras mielinicas da comissura anterior, em ratos albinos Wistar submetidos a hidrocefalia experimental, quando considerados: grau de dilatação ventricular e tempo de progressão da hidrocefalia. Para isto foram utilizados ratos albinos Wistar com sete dias de vida e induzidos a hidrocefalia com injeção intracisternal de caulim a $20 \%$ e divididos em dois grupos: com 14 e 21 dias de evolução da hidrocefalia, ambos com seus respectivos controles. Posteriormente os animais foram anestesiados e perfundidos por via transcardiaca com uma solução salina tamponada, seguida por uma mistura fixadora de paraformaldeido a $2 \%$ e glutaraldeido a $1 \%$ diluidos em tampão fosfato. Posteriormente as comissuras foram dissecadas, pos-fixadas em tetroxido de ósmio e citrato de chumbo, e incluídos em resina epoxi. Foram realizados cortes ultrafinos para analise ultraestrutural. Ao microscopio eletrônico de transmissão foram analisadas as fibras nervosas 
mielinicas e celulas gliais, onde pode-se notar que, apesar de não significante, ocorreram lesões tanto nas fibras mielínicas quanto nas 6 organelas citoplasmaticas das celulas gliais, principalmente nos animais com hidrocefalia grave, mostrando assim que a comissura e suscetível as lesões provocadas pela hidrocefalia e a importância do diagnostico precoce para evitar o agravamento das lesões.

\title{
ANÁLISE MORFOLÓGICA E MORFOMÉTRICA DAS ADAPTAÇÕES DO CORAÇÃO DE RATO ALBINO- WISTAR ADULTO SUBMETIDO A EXERCÍCIO FÍSICO AERÓBIO EM ESTEIRA ERGOMÉTRICA
}

\author{
Patricia Daniela Sicchieri Silva
}

Orientador: Prof. Dr. José Antonio Thomazini

Dissertação de Mestrado apresentada em 29/10/2010

O exercício aeróbio utiliza a energia produzida pelo metabolismo aeróbio e é caracterizado por sessões de longa duração e de baixa a média intensidade. Sua prática regular traz vários benefícios para a saúde e o coração é um dos órgãos mais beneficiados com essa prática e um dos mais prejudicados com o estilo de vida sedentário. Vários estudos demonstram as adaptações do coração em resposta ao exercício aeróbio, porém poucos observam estes benefícios em indivíduos adultos, quando as consequências do processo natural de envelhecimento sobre o coração começam a se tornar evidentes. O objetivo deste estudo foi investigar alterações de diversos parâmetros morfológicos e morfométricos do coração de ratos albinos-Wistar adultos, submetidos a exercício aeróbio em esteira ergométrica. Para tanto, foram utilizados inicialmente 24 animais machos adultos, normais, ígidos, albinos da variedade Wistar com peso médio inicial de $350 \mathrm{~g}$, sendo 12 pertencentes ao Grupo C (controle) e 12 ao Grupo T (treinado). Os animais do Grupo T foram submetidos a protocolo de treinamento aeróbio em esteira ergométrica durante 10 semanas, enquanto os animais do Grupo C permaneceram sedentários pelo mesmo período. Após o período de treinamento os animais foram pesados, anestesiados e em seguida foram sacrificados para retirada dos corações. Os corações foram pesados, obtidos os índices cardiossomáticos, e medida a distância do sulco atrioventricular ao ápice do coração. Em seguida os corações foram seccionados através de um corte longitudinal e suas porções anteriores foram submetidas à técnica histológica de rotina para parafina e foram realizados dois tipos de colorações, HE e picrosirius. Os cortes longitudinais corados em HE foram utilizados para as análises morfológica e morfométrica. Nos cortes corados com picrosirius foram realizadas quantificação e tipificação de fibras colágenas miocárdicas do VE. Os animais chegaram ao final do experimento com o mesmo peso corporal. O peso do coração e ICS foram maiores nos animais controle e a distância do sulco atrioventricular foi maior nos animais treinados, apesar dessas diferenças, não se apresentarem em valores estatisticamente significantes. Não foram observadas diferenças no aspecto morfológico do miocárdio do VE analisado entre os grupos. As medidas de área total, da cavidade e da parede do VE também não tiveram significância estatística. Em valores percentuais em relação à área ventricular total, as áreas total e da cavidade do VE foram maiores nos animais treinados, e a área da parede do VE apresentou percentuais iguais em ambos os grupos, o que parece ser compatível com padrões de hipertrofia excêntrica do VE. O diâmetro dos miócitos não apresentou diferença entre os grupos, porém o grupo treinado apresentou maior densidade dessas células e de vasos sanguíneos pérvios, esses resultados podem demonstrar que o exercício reduziu a perda de miócitos e vasos sanguíneos que ocorrem naturalmente com o envelhecimento do miocárdio. Não houve diferenças na densidade de fibroblastos, na quantificação de percentual de fibras colágenas totais e de fibras do Tipo III entre os grupos, mas houve uma diferença significante no percentual de fibras colágenas Tipo I, sendo o grupo treinado o que apresentou maior percentual; esses valores parecem indicar que, apesar de não haver aumento de percentual de colágeno total no miocárdio, houve uma manutenção no equilíbrio de tipos de fibras colágenas nos animais treinados. Em conclusão temos que o exercício aeróbio utilizado produziu alterações morfoquantitativas no VE de ratos adultos, normais e saudáveis que parecem ter promovido um efeito anti-envelhecimento no coração desses animais e que, apesar de alguns valores numéricos não terem sido estatisticamente significantes, há indícios de uma hipertrofia ou dilatação excêntrica no VE dos animais treinados. 


\title{
Clínica Médica
}

\section{MICROBIOTA INTESTINAL DE PACIENTES PORTADORES DA SÍNDROME DO INTESTINO CURTO}

\author{
Eduarda de Castro Furtado \\ Orientadora: Profa. Dra. Vivian Marques Miguel Suen \\ Dissertação de Mestrado apresentada em 1\%10/2010
}

A Síndrome do Intestino Curto (SIC) é definida como um conjunto de sinais e sintomas consequentes de alterações nutricionais e metabólicas secundária a insuficiência intestinal funcional ou orgânica, como nos casos de grandes ressecções do intestino delgado. Ressecções intestinais eliminam sítios de colonização, alteram a área de absorção e, o uso frequente de antibióticos devido a infecções recorrentes, presença de alimentos não digeridos no trato intestinal remanescente, trânsito acelerado e diarréias constantes, nestes mesmos pacientes, podem contribuir para a alteração da microbiota intestinal.Objetivo: Caracterizar a microbiota intestinal de pacientes portadores da Síndrome do Intestino Curto atendidos na Unidade Metabólica e do HCFMRP/USP. Material e Métodos: Foram recrutados os pacientes portadores de síndrome do intestino curto atendidos na Unidade Metabólica do HCFMRP/USP (uso de terapia nutricional parenteral). Para o grupo controle foram recrutados indivíduos sadios e eutróficos da comunidade e pareados segundo sexo e idade. Foram avaliadas amostras de fezes e exames bioquímicos, estes últimos serão somente dos pacientes. A avaliação do estado nutricional foi feita a partir de medidas antropométricas e a avaliação do consumo alimentar por meio de do inquérito Diário Alimentar. Para detecção de cepas patogênicas foram realizados cultivos e testes bioquímicos específicos em meio aeróbio para determinação de espécies da família Enterobacteriaceae. Em cada cepa de E. coli isolada foram aplicados anti-soros para determinação de possível patogenicidade. Metodologia molecular também foi utilizada para determinação do perfil da microbiota intestinal bacteriana: sequenciamento de bibliotecas de DNAr 16S e PCR para detecção de genes característicos de cepas patogênicas de E. coli. Resultados: Verificou-se a presença de subnutrição protéico-calórica no grupo Paciente mesmo com terapia nutricional para recuperação deste estado nutricional. Quanto a microbiota, observou-se maior diversidade, porém menor quantidade por grama de fezes da família Enterobacteriaceae em pacientes com SIC. Porém a análise molecular mostrou a manutenção na proporção de espécies bacterianas, equivalente a microbiota intestinal saudável. Conclusão: Apesar da subnutrição, retirada maciça do intestino delgado, uso frequente de antibióticos, depressão do sistema imune, presença de alimentos não digeridos no trato gastrintestinal e transito intestinal acelerado, a relação e proporção entre as espécies bacterianas intestinais permanecem similares à normalidade.

\section{AVALIAÇÃO VIDEOFLUOROSCÓPICA DA DEGLUTIÇÃO ANTES E APÓS A TIREOIDECTOMIA}

\author{
Geruza Costa Gonzaga \\ Orientador: Prof. Dr. Roberto Oliveira Dantas \\ Tese de Doutorado apresentada em 05/10/2010
}

Pacientes com lesões tireoidianas podem desenvolver disfagia como resultado da compressão dos órgãos relacionados à deglutição, ou por envolvimento nervoso, em decorrência da invasão do carcinoma tireodiano; ou por consequência de tratamentos como a tireoidectomia ou terapia radioterápica. A faringe e a laringe, em sua complexidade sensória e motora, pode ser atingida durante a tireoidectomia, mesmo na ausência de lesões dos nervos laríngeos, podendo gerar alterações no trânsito orofaríngeo. O objetivo do trabalho foi averiguar as queixas de disfagia, e avaliar, por meio do exame videofluoroscópico da deglutição, as fases oral e faríngea da deglutição, antes e após a tireoidectomia. Para tal, 38 indivíduos, média de idade 47,21 11 anos, foram avaliados quanto aos fenômenos da deglutição orofaríngea: tempo de movimentação do osso hióide (TMH); trânsitos: oral (TO), faríngeo (TF), orofaríngeo (TOF), trânsito do alimento pelo segmento faringoesofágico (TSFE); depuração faríngea (DF); latência da movimentação faríngea (LMF) e tempo de residência do alimento sobre o segmento faringoesofágico (TRSFE). Os resultados videofluoroscópicos foram comparados entre o próprio grupo nos dois diferentes momentos avaliados e também a um grupo controle, composto por 21 indivíduos saudáveis, média de idade $44 \pm 16$ anos. Todos os sujeitos foram submetidos a um questionário referente às queixas de deglutição e ao exame videofluoroscópico, antes e após a cirurgia. Dentre os 38 pacientes avaliados, 26 realizaram a avaliação de forma completa, ou seja, foram avaliados os dois períodos propostos: pré e pós-operatório. A tireoidectomia total se deu em $71 \%$ dos casos e $29 \%$ dos pacientes se submeteram à tireoidectomia parcial. Em dois casos (5,26\%) houve esvaziamento cervical. Antes da tireoidectomia $(\mathrm{n}=38), 27$ pacientes $(70 \%)$ apresentaram queixas de dificuldades de deglutição e após (n=26), 20 (76,9\%) apresentaram-nas. As principais queixas no período pré-operatório foram: desconforto 
durante a deglutição (52,6\%); presença de engasgos e tosses $(52,6 \%)$ e medo de deglutir (18,42\%). Tais queixas, provavelmente ocorreram por ocasião da compressão exercida pelos nódulos tireoidianos nas regiões do esôfago, traquéia e nervos laríngeos. As queixas que predominaram no período pós-operatório foram: dor ao deglutir (57,6\%), desconforto orofaríngeo $(34,6 \%)$, tosses e engasgos $(30,7 \%)$, medo de deglutir $(26,9 \%)$ e falta de ar $(3,84 \%)$. Quanto as medidas dos intervalos de tempo dos diferentes fenômenos da deglutição avaliados observou-se: na deglutição de 5 ml da consistência líquida, diferença significativa $(\mathrm{p}=0,03)$ na medida da LMF entre os pacientes nos períodos pré e pós-operatório; diferença significativa $(\mathrm{p}=0,04)$ entre as medidas do TRSFE, entre o grupo controle e pacientes avaliados após a tireoidectomia; valor de $\mathrm{p}=0,04$, na comparação da medida do TSFE, entre controles e pacientes no momento pós-operatório. Na deglutição de $5 \mathrm{ml}$ da consistência pastosa, houve diferença significativa ( $\mathrm{p}=0,01)$ na medida do TSFE na comparação entre os pacientes nos períodos pré e pós-operatório. Na deglutição de $10 \mathrm{ml}$ da consistência pastosa, houve diferença significativa ( $\mathrm{p}=0,01)$ na medida do TSFE, entre controles e pacientes, no momento pós-operatório. Na medida da DF, o valor de $\mathrm{p}$ foi menor que 0,01 ; quando comparados os pacientes nos dois momentos avaliados. Na comparação exclusiva dos pacientes no momento pré-operatório e controles, observou-se: na deglutição de $5 \mathrm{ml}$ da consistência líquida e $5 \mathrm{ml}$ da consistência pastosa, os valores de $\mathrm{p}$ foram, respectivamente, $\mathrm{p}=0,01$ e $\mathrm{p}<0,01$, na medida do TRSFE. Na deglutição de 10 $\mathrm{ml}$ da consistência pastosa, houve diferença significativa $(\mathrm{p}=0,01)$ na medida da DF. Na medida do TRSFE, o valor de $\mathrm{p}$ foi significativo $(\mathrm{p}<0,01)$ entre os dois grupos avaliados. A penetração laríngea ocorreu exclusivamente em um paciente, antes da realização da tireoidectomia. Não houve aspiração do bolo alimentar para a traquéia, nos indivíduos estudados. Os pacientes tireoidectomizados, de uma maneira geral, apresentaram pequenas alterações na deglutição orofaríngea. Tais alterações ocorreram provavelmente em decorrência da diminuição do movimento vertical laríngeo provocado pela manipulação cirúrgica, a qual acarretou dificuldades na abertura do segmento faringoesofágico. No entanto, as alterações observadas não foram limitantes, não impossibilitando a alimentação oral.

\title{
INFLUÊNCIA DE MICRONUTRIENTES NA ABSORÇÃO DE FERRO: ESTUDOS in vitro E in vivo
}

\author{
Fabiola Rainato Gabriel \\ Orientador: Prof. Dr. José Eduardo Dutra \\ Tese de Doutorado apresentada em 27/10/2010
}

O objetivo do presente estudo é verificar a influência de micronutrientes na absorção do ferro. Foram realizados no estudo in vitro 14 experimentos para determinação da porcentagem de ferro dialisado. Os experimentos realizados foram: ferro (10mg); ferro (10mg) e vitamina C (75, 150 e $300 \mathrm{mg})$; ferro (10mg) e cálcio (300, 600 e 1200mg); ferro e vitamina A (450, 900 e $1800 \mathrm{ug})$; ferro (10mg) e zinco (10, 20 e 30mg); branco. O estudo in vivo trata-se de um ensaio clínico randomizado, controlado, duplo-cego, com voluntários adultos, saudáveis do sexo masculino, com índices hematimétricos dentro da normalidade. Realizou-se 8 experimentos por grupo (1 e 2). No grupo 1 foram: ferro (10mg); ferro (10mg) e vitamina C (75, 150 e $300 \mathrm{mg}$ ); ferro (10mg) e cálcio (300, 600 e 1200mg); placebo. No grupo 2 os experimentos foram: ferro (10mg); ferro (10mg) e vitamina A (450, 900 e $1800 \mathrm{ug})$; ferro (10mg) e zinco (10, 20 e 30mg); placebo. Os voluntários permaneceram em jejum por oito horas. Foram coletadas amostras de sangue basal (T0) para dosagem de hemograma completo, minerais (ferro e cálcio ou zinco), ferritina, e vitaminas C e A. Em seguida, os voluntários receberam os compostos avaliados, acompanhado de $200 \mathrm{~mL}$ de água. Permaneceram em jejum por mais 4 horas, coletado amostras em 2 (T1) e 4 (T2) horas. O ferro, cálcio e zinco foram determinados no aparelho Inductively coupled plasma mass spectrometry. A determinação dos níveis de ferritina no soro foi por método imunométrico: imunoensaio enzimático quimioluminescente. Para dosagem do retinol plasmático utilizou-se cromatografia líquida de alta eficiência e a dosagem de vitamina C empregou-se o método fotométrico. Analisou-se as curvas séricas, a soma da área sob a curva (AUC), ajustada ao modelo linear de efeitos mistos $(\mathrm{p}<0,05)$. A absorção de cálcio in vitro apresentou baixa disponibilidade de ferro independentemente da dose, entretanto pelo método in vivo, o cálcio nas diferentes doses não interagiu negativamente com o ferro $(\mathrm{p}<0,05)$. Pelo método in vitro e in vivo, verificou-se que, na dose de 1:2 de ferro e zinco, houve influência negativa na absorção de ferro. A monitoração de ferro sérico e zinco influenciou negativamente também na proporção $1: 1(\mathrm{p}<0,05)$. No estudo in vivo, não ocorreu diferença significativa, com o experimento com ferro isolado e na presença de vitamina $\mathrm{C}$, independentemente da dosagem. Portanto, o que parece é que a vitamina $\mathrm{C}$ exerce um efeito potencial na presença de inibidores da absorção. A vitamina $\mathrm{A}$, em dose alta, pode ocasionar níveis de ferro sérico menor. Porém, nas dosagens inferiores, tem efeito similar ao da vitamina C. Não houve correlação em relação à absorção de ferro in vitro e in vivo. Em relação ao cálcio e zinco dialisável, ocorreu correlação com método in vivo. Portanto, estudos com intuito de avaliar a biodisponibilidade de um nutriente e a interrelação dos nutrientes deveriam envolver procedimentos metodológicos in vitro e in vivo, para garantir que todas as possibilidades e processos referentes ao aproveitamento do nutriente sejam conhecidos e monitorados, utilizados isoladamente ou 
em combinações. Palavras Chaves: absorção do ferro; interações de nutrientes; formulações nutricionais; biodiponibilidade; zinco, cálcio; vitamina C; vitamina A; anemia ferropriva.

\title{
POLIMORFISMOS DO FATOR DE NECROSE TUMORAL E DOS ANTÍGENOS LEUCOCITÁRIOS HUMANOS HLA-C E HLA-G NO SANGUE E EXPRESSÃO DO HLA-G NA PELE DE PACIENTES COM PSORÍASE
}

\author{
Renata Nahas Cardili \\ Orientadora: Profa. Dra. Cacilda da Silva Souza \\ Tese de Doutorado apresentada em 19/11/2010
}

Psoríase é doença inflamatória crônica de etiologia multifatorial, que afeta predominantemente pele e articulações. Apesar da variabilidade dos antígenos leucocitários humanos [HLA] nos diferentes grupos étnicos e populacionais, evidências indicam a sua associação com a susceptibilidade à psoríase, na qual outras características imunogenéticas podem estar envolvidas. A interação entre células T, antígenos HLA e queratinócitos desencadearia exacerbação da resposta imune celular com níveis elevados do fator de necrose tumoral-alfa [TNF-alfa]. A imunomodulação teria papel crítico na recuperação do equilíbrio no balanço entre células $T$ efetoras e supressoras e controle da doença. Neste contexto, a expressão das moléculas do HLA-G, com ação amplamente inibitória, poderia estar relaciona da à tolerância imunológica, em condições patológicas diversas, como nas doenças autoimunes. Neste estudo, polimorfismos do HLA-C, TNF- $\alpha$ e HLA-G de amostras do sangue e expressão molecular do HLA-G, em amostras cutâneas, foram analisados por meio de extração de DNA, reação em cadeia da polimerase-SSP e imunoistoquímica, de psoriáticos (n=129) e controles saudáveis (n=202) provenientes Ribeirão Preto e região. As análises estatísticas foram realizadas com o programa GrafPad Instat 3.05 software. Na amostra de psoriáticos, houve predomínio de caucasianos, idade média 42,1 anos e discreto predomínio do sexo masculino. A forma clínica predominante foi a vulgar $(79,8 \%)$, seguida da eritrodérmica $(9,4 \%)$ e artropática $(10,1 \%)$. A história familial foi positiva em $20,9 \%$ da amostra, destes a expressiva maioria $(81,5 \%)$ apresentava início precoce da doença. As frequências foram significantemente superiores dos alelos HLA-Cw*06 ( $\mathrm{p}=0,0005)$ e TNF- $\alpha$ 308-A em psoriáticos ( $\mathrm{p}=0,0061)$, do alelo HLA- $\mathrm{Cw} * 06$ nos pacientes com início precoce da doença $(\mathrm{p}=0,0389)$ e do alelo TNF- $\alpha$ 308-G nos controles ( $\mathrm{p}=0,05$ ). O haplótipo 238A/308G/HLACw*6 foi significantemente mais frequente nos psoriáticos ( $\mathrm{p}=0,0253$ ), enquanto que o haplótipo 238G/308G/HLACw*15, nos controles ( $\mathrm{p}=0,0377$ ). Quanto ao polimorfismo genético isolado do HLA-G, não foram observadas diferenças entre os grupos. A expressão das moléculas do HLA-G foi detectada em 90\% (27/30) das amostras de pele lesada, principalmente em queratinócitos da epiderme; e em 27,2\% (3/11) das amostras de pele perilesional, a despeito das evidências de normalidade. Distintamente, a expressão das moléculas do HLA-G foi negativa em todas as amostras na pele normal dos controles $(n=32)[p<0,0001]$. A intensidade da expressão do HLA-G não foi associada ao tipo de psoríase I ou II, ao índice de severidade e de área acometida da doença (PASI) ou às diferentes formas clínicas. Não houve relação entre a expressão cutânea do HLA-G e a presença do alelo HLA-Cw*06 ou polimorfismos do HLA-G e do TNF- $\alpha$. Os achados comparados à literatura indicam concordância com a frequência estatisticamente superior do alelo HLA-Cw*06 nos psoriáticos, em particular naqueles com início precoce da doença, mas discordância em relação à frequência significantemente superior do alelo TNF- $\alpha 308-\mathrm{A}$, observada em nossos pacientes. A frequência elevada do haplótipo 238A/308G/HLACw*06 nos psoriáticos e do 238G/308G/HLACw*15 nos controles poderia sugerir susceptibilidade e proteção à doença, respectivamente. A marcante expressão do HLA-G na epiderme lesada de psoriáticos é indicativa da participação dessas moléculas com possível ação imunomoduladora, na contenção ou limitação das alterações inflamatórias e proliferativas na psoríase.

\section{INFLUÊNCIA DO TRATAMENTO ANTIVIRAL NO PERFIL DAS CITOCINAS IL-2, IFN- $\gamma$, IL-4 E IL-10 DETECTADAS EM SOBRENADANTE DE CULTURAS DE CÉLULAS MONONUCLEARES DO SANGUE PERIFÉRICO DE PACIENTES COM HEPATITE C CRÔNICA}

\author{
Maíra Peres Ferreira \\ Orientadora: Profa. Dra. Ana de Lourdes Candolo Martinelli \\ Tese de Doutorado apresentada em 06/12/2010
}

Atualmente a hepatite $\mathrm{C}$ crônica é um grave problema de saúde pública, acometendo cerca de $3 \%$ da população mundial, ou 170 milhões de indivíduos. Uma das características mais relevantes do vírus da hepatite C (VHC) é a sua 
heterogeneidade genética, que parece resultar da pressão imunológica gerada pelo sistema imune do hospedeiro e que determina o surgimento de diferentes genótipos, com variados subtipos. O tratamento da hepatite C com interferon-alfa, peguilado ou não-peguilado, associado à ribavirina, conduz à erradicação viral em somente uma parcela dos casos, dependendo do genótipo viral e de peculiaridades relacionadas aos pacientes. Existem poucos estudos avaliando a influência da resposta imune, por meio do perfil de produção de citocinas, sobre a cinética do VHC durante o tratamento da hepatite C crônica. Assim, existe grande interesse em avaliar a influência desse perfil de resposta imune e da produção de citocinas por linfócitos do paciente sobre a cinética do VHC, durante o tratamento da hepatite crônica, com vistas a melhor compreender fatores implicados nos diferentes tipos de resposta ao tratamento. Dessa forma, foram quantificados, in vitro, as citocinas IL-2, IFN- $\gamma$, IL-4 e IL-10 em pacientes com hepatite C crônica pelo VHC, genótipo 1 (1a e 1 b), antes e durante o primeiro mês de tratamento com PEG-IFN $\alpha$ 2a/2b associado à ribavirina, após estímulos específico (epítopo do vírus C) e inespecífico (fitohemaglutinina-PHA). Tivemos como objetivos avaliar a relação da produção de citocinas com os tipos de respostas virológicas apresentadas pelos pacientes, definidas de acordo com o tempo de tratamento (resposta virológica na $1^{\mathrm{a}}$ semana - RV $1^{\mathrm{a}}$ sem., resposta virológica rápida - RVR, resposta virológica precoce - RVP, resposta virológica ao final do tratamento - RVFT e a ausência de resposta - NR) e com a viremia do VHC. Na casuística analisada, o percentual dos pacientes que tiveram RVFT foi de $54 \%$. A taxa de pacientes que tiveram RV na $1^{\mathrm{a}}$ semana foi de $26 \%, 22 \%$ tiveram RVR e 56\% apresentaram RVP. As citocinas dosadas a partir de culturas estimuladas com o vírus C não foram incluídas, pois apresentaram concentrações muito baixas e semelhantes às quantificadas a partir da cultura sem estímulo (basal). Apesar dos valores de todas as citocinas dosadas no sobrenadante da cultura de linfócitos estimulada pela PHA terem sido maiores no grupo de pacientes com RVFT do que nos NR, em todas as semanas avaliadas, nenhuma diferença significativa em relação ao padrão de resposta celular e humoral (Th1 e Th2) foi observada. A produção de IFN-ã foi mais elevada nos pacientes com RVFT a partir da semana 1 quando comparados aos NR e, comparando-se a semana 0 com a semana 1 notou-se valores maiores na semana $1 \operatorname{com} p=0,064$ nos pacientes com RVFT. Essa tendência não foi observada no grupo NR $(p=0,12)$. Houve diferença significativa entre a produção de IL-2 dosados na semana 0 e na $2^{\mathrm{a}}$ semana (valores maiores na semana 2) de tratamento antiviral no grupo dos RVFT ( $p=0,042)$. Essa diferença não foi observada no grupo dos não respondedores. Quando avaliou-se a correlação entre viremia e produção de citocinas no sobrenadante de cultura de linfócitos estimulada pela PHA, uma correlação significativa ( $p=0,02$ e r2 = - 0,47) foi observada apenas quando analisada a citocina IL-10 na $2^{\text {a }}$ semana de tratamento nos pacientes com baixa carga viral nesse período (d"400.000 UI/ml). Assim, nossos resultados sugerem que o aumento da citocina IFN-ã na primeira semana após o início do tratamento antiviral e da IL-2 na segunda semana de tratamento antiviral estejam relacionados à resposta final ao tratamento antiviral. Essas respostas poderiam identificar precocemente os pacientes respondedores ao tratamento. Cargas virais maiores se correlacionam com menores níveis de IL-10 em situações de baixa viremia.

\title{
PERMEABILIDADE INTESTINAL E ESTADO NUTRICIONAL EM PACIENTES COM NEOPLASIAS HEMATOLÓGICAS TRATADOS COM QUIMIOTERAPIA
}

\author{
Nilian Carla de Souza \\ Orientadora: Profa. Dra. Paula Garcia chiarello \\ Dissertação de Mestrado apresentada em 16/12/2010
}

Quimioterapia apresenta efeitos colaterais prejudiciais ao trato digestivo e ao estado nutricional. Acredita-se que existam conexões entre a quimioterapia, o estresse oxidativo e os danos à mucosa intestinal. Um dos testes utilizados na verificação da permeabilidade intestinal é o de dosagem de açúcares não metabolizáveis, como o manitol e a lactulose. Este trabalho tem como objetivo avaliar a permeabilidade intestinal e o estado nutricional em indivíduos com neoplasias hematológicas durante um ciclo de quimioterapia. Avaliaram-se as medidas de permeabilidade intestinal (coleta de toda a urina antes e 5 horas após a ingestão, em jejum, de $150 \mathrm{ml}$ de solução de manitol, 2,0 g, e lactulose, 7,5g) e a mucosite (grau dos sintomas e sinais gastrintestinais apresentados) no período anterior e após ciclo de quimioterapia. As variáveis dietéticas (registros alimentares) e antropométricas (relação peso/altura ${ }^{2}$, circunferências e pregas cutâneas), os dados de composição corporal (bioimpedância elétrica) e os exames bioquímicos (albumina, alfa tocoferol, ácido ascórbico, beta caroteno e ácido fólico séricos) também foram analisados. A razão laculose/manitol (L/M) aumentou em decorrência da maior absorção de lactulose. O consumo calórico e de macronutrientes apresentou diminuição decorrente da presença de 
sintomas gastrintestinais como perda de apetite, náusea, vômito, alteração do paladar e disfagia. O consumo de micronutrientes foi inadequado em ambos os períodos (antes e durante o ciclo de quimioterapia). A qualidade da dieta apresentou piora durante o ciclo de quimioterapia. A maioria dos indivíduos $(68,2 \%)$ apresentou perda de peso e $27,3 \%$ ganharam peso nos primeiros meses de tratamento quimioterápico. No momento do estudo, 45,0\% dos indivíduos eram eutróficos, 32,0\% apresentavam sobrepeso e 23,0\% risco nutricional ou baixo peso. Durante o ciclo de quimioterapia avaliado, não ocorreram modificações nas medidas antropométricas. Apenas o ângulo de fase apresentou queda possivelmente causada pela diminuição da massa celular corporal e redistribuição de fluídos. Houve diminuição nos níveis do alfa tocoferol, sendo que a concentração de alfa tocoferol já se encontrava abaixo dos valores de referência no período basal. Os níveis do ácido ascórbico e do ácido fólico foram inferiores aos do grupo de indivíduos saudáveis no período basal e após ciclo de quimioterapia. Os valores de beta caroteno foram inferiores aos dos indivíduos saudáveis após o ciclo de quimioterapia. A razão L/M apresentou relação inversa com o ângulo de fase e o IMC, e estava diretamente associada à presença de náusea. Além disso, o delta da razão L/M pós - quimioterapia foi inversamente associado ao IMC após 30 dias do ciclo de quimioterapia. $\mathrm{O}$ aporte insuficiente de vitaminas e a diminuição dos níveis plasmáticos de vitaminas antioxidantes são fatores adicionais na geração de radicais livres além de trazer prejuízos à renovação da mucosa intestinal (ácido fólico). Estes fatores, somados ao aumento do estresse oxidativo e às alterações ocorridas na permeabilidade intestinal (via paracelular), podem comprometer o estado nutricional de forma contínua neste período crítico.

\title{
Farmacologia
}

\section{ENVOLVIMENTO DAS REDES NEURAIS DO Locus Coeruleus E DA NEUROTRANSMISSÃO NORADRENÉRGICA NO NÚCLEO DORSAL DA RAFE E NO HIPOTÁLAMO MEDIAL NAS REAÇÕES DE FUGA EVOCADAS PELA ESTIMULAÇÃO QUÍMICA DO HIPOTÁLAMO MEDIAL}

\author{
Andrés Uribe Mariño \\ Orientador: Prof. Dr. Norberto Cysne Coimbra \\ Dissertação de Mestrado apresentada em 07/10/2010
}

A estimulação de regiões mesencefalicas como a substância cinzenta periaqueductal, camadas profundas do colículo superior e núcleo central do coliculo inferior, eliciam respostas defensivas semelhantes àquelas que caracterizam a síndrome do pânico. Tem sido estabelecido que o bloqueio do receptor GABAA no hipotálamo medial induz reações defensivas mais organizadas e menos intensas. Métodos utilizando neurotraçadores de captação e transporte retrógrado têm identificado conexões do hipotálamo medial com o núcleo dorsal da rafe e o locus coeruleus, assim como conexões recíprocas entre esses dois núcleos do tronco cerebral. O objetivo do presente projeto foi estudar o papel das redes neurais do Locus Coeruleus e da neurotransmissão noradrenérgica no núcleo dorsal da rafe e no hipotálamo nas reações de pânico evocadas pela estimulação química do hipotálamo medial. O projeto foi dividido em três estudos. 1) Estudo Neurofisiológico: Ratos Wistar machos foram submetidos à cirurgia estereotáxica para implantação de cannulas-guias no Locus Coeruleus e no hipotálamo medial. Durante a cirurgia, microinjeções da neurotoxina noradrenérgica DSP-4 $(1 \mu \mathrm{g} / 0.2 \mu \mathrm{l})(\mathrm{n}=8)$ ou procedimentos Sham $(\mathrm{n}=8)$ foram realizadas diretamente no locus coeruleus. Cinco dias depois, microinjeções de bicuculina (40ng/0.2 $\mu \mathrm{l}$ ) foram realizadas no hipotálamo medial. 2) Estudo Neurofarmacológico no núcleo dorsal da rafe: Ratos Wistar machos foram submetidos à cirurgia estereotáxica para implantação de cannulas-guias no núcleo dorsal da rafe e no hipotálamo medial. Cinco dias após a cirurgia, os animais foram pré-tratados no núcleo dorsal da rafe com solução salina $(\mathrm{NaCl}$ a $0,9 \% ; 0.2 \mathrm{~L}, \mathrm{n}=8)$ ou um dos antagonistas noradrenérgicos WB4101 $\left(\alpha_{1}, \mathrm{n}=8\right), \mathrm{RX} 821002\left(\alpha_{2}, \mathrm{n}=8\right)$ ou propanolol $(\beta, \mathrm{n}=8)$ em uma concentração de $5 \mu \mathrm{g} / 0.2 \mu \mathrm{l}$. Dez minutos depois, foi administrada bicuculina $(40 \mathrm{ng} / 0.2 \mu \mathrm{l})$ no hipotálamo medial. 3) Estudo Neurofarmacológico no hipotálamo medial: Ratos Wistar machos foram submetidos à cirurgia estereotáxica para a implantação de uma cannula-guia no hipotálamo medial. Cinco dias após a cirurgia, os animais foram pré-tratados com solução salina ( $\mathrm{NaCl}$ a $0,9 \% ; 0.2 \mathrm{~L}, \mathrm{n}=8)$ ou um dos antagonistas noradrenérgicos WB4101 $\left(\alpha_{1}, \mathrm{n}=8\right), \mathrm{RX} 821002\left(\alpha_{2}\right.$, $\mathrm{n}=8$ ) ou propanolol $(\beta, \mathrm{n}=8)$ em uma concentração de $5 \mu \mathrm{g} / 0.2 \mu \mathrm{l}$. Dez minutos depois, foi administrada bicuculina (40ng/0.2 $\mu \mathrm{l})$ no hipotálamo medial. Nos estudos citados, imediatamente após a microinjeção de bicuculina, os animais foram colocados no teste de campo aberto, onde número de cruzamentos e frequência e duração dos seguintes comportamentos foram registrados durante 15 minutos: levantamentos, avaliação de risco, atenção defensiva, movimento defensivo retrógrado, comportamento rotatório, fuga e saltos. Os dados obtidos mostram que a lesão do Locus Coeruleus e o antagonis- 
mo de receptores $\alpha_{1}$ e $\beta$ no núcleo dorsal da rafe e no hipotálamo medial induzem uma diminuição significativa na expressão dos comportamentos defensivos evocada pela estimulação do hipotálamo medial. Também, observou-se um aumento significativo em algumas respostas comportamentais após o bloqueio dos receptores $\alpha_{2}$ nas duas estruturas. Assim, os achados do presente trabalho indicam que as vias que conectam o Locus Coeruleus com o núcleo dorsal da rafe e o hipotálamo medial, através de sua ação sobre os receptores $\alpha_{1}, \alpha_{2}$ e $\beta$ noradrenérgicos, modulam as respostas defensivas evocadas pela estimulação do hipotálamo medial.

\title{
PAPEL DO SISTEMA OPIOIDE E DAS CONEXÕES ENTRE O HIPOTÁLAMO MEDIAL E A SUBSTÂNCIA CINZENTA PERIAQUEDUTAL NOS COMPORTAMENTOS DE DEFESA ELICIADOS PELO BLOQUEIO DE RECEPTORES GABAA NO HIPOTÁLAMO MEDIAL
}

\author{
Maria Angélica Castiblanco Urbina \\ Orientador: Prof. Dr. Norberto Cysne Coimbra \\ Dissertação de Mestrado apresentada em 13/10/2010
}

A síndrome do pânico é caracterizada por ataques de pânico, os quais são considerados como episódios de medo intenso acompanhados por palpitações, sensação de morte iminente e perda de controle, entre outros. Existem modelos experimentais que tentam reproduzir os sintomas da síndrome de pânico através da estimulação de diferentes estruturas encefálicas, com o intuito de investigar as bases fisiológicas e farmacológicas dessa patologia, culminando em achados que favoreçam o descobrimento de novos tratamentos. A estimulação elétrica e química de algumas estruturas mesencefálicas, tais como a substância cinzenta periaquedutal dorsal (SCPd), as camadas profundas do colículo superior (CPCS) e o núcleo central do colículo inferior (NCCI) eliciam respostas defensivas explosivas, associadas ao medo e semelhantes àquelas que caracterizam a síndrome do pânico em humanos. O medo, presente no transtorno de pânico, pode ser considerado como uma emoção inata que induz a organização de um comportamento defensivo inato que caracteriza o instinto de sobrevivência das espécies, permitindo ao indivíduo se proteger de situações aversivas, perigosas e ameaçadoras. Curiosamente, após a estimulação intra-hipotalâmica, a resposta defensiva de fuga é caracterizada por ter uma intensidade moderada, e por ser rica em comportamento exploratório. O objetivo do presente trabalho foi estudar o papel das conexões entre os núcleos do hipotálamo medial (HM) e a SCPd, com especial ênfase no sistema opioide, e seu envolvimento na modulação dos comportamentos defensivos elaborados pela estimulação química do HM através de uma abordagem neurofisiológica, com inativação de sinapses através da administração com cloreto de cobalto na SCPd, e por meio de uma abordagem neurofarmacológica, com pré-tratamento na SCPd com antagonistas seletivos e não-seletivos de receptores opioides. Para isso, foi feita uma cirurgia estereotáxica e uma cânula foi implantada na SCPd e outra no HM. Em uma abordagem neuroanatômica, a droga neurotraçadora biodextrana (BDA) marcada com Cascade Blue (BDA-CB) ou com Texas Red (BDA-TR) foi administrada no HM e na SCPd, respectivamente. Esse procedimento permitiu a identificação de células com características de neurônios localizadas no núcleo ventromedial do hipotálamo (HVM), e fibras na SCPd, sugerindo que o HVM projeta-se tanto para o HDM como para a SCPd. Foram também identificados neurônios positivos para BDA-TR nas colunas dorsais da SCPd, no núcleo dosomedial do hipotálamo (HDM), o que pode sugerir uma rede neural conectando reciprocamente o $\mathrm{HM}$ à SCPd, além das já conhecidas conexões intrísecas no HM e na própria SCP. No estudo neurofisiológico, cinco dias após a cirurgia, os animais foram divididos em dois grupos. O primeiro foi submetido ao procedimento de pseudomicroinjeção (Sham) na SCPd e, após dez minutos, recebeu a microinjeção de bicuculina (40ng/ $0,2 \mu \mathrm{L})$ no HM. Por sua vez, o segundo grupo recebeu a microinjeção de Cloreto de cobalto (1mmol) na SCPd seguido, após dez minutos, por microinjeções de bicuculina $(40 \mathrm{ng} / 0,2 \mu \mathrm{L})$ nas redes neurais do HM. No estudo neurofarmacológico, os animais receberam salina fisiológica, naltrexona, nor-binaltorfimina ou naloxonazine na SCPd e, após 10 minutos, 2 horas ou 24 horas, respectivamente, foram tratados com microinjeção de bicuculina (40ng/0,2 $\mu \mathrm{L})$ no HM. Imediatamente após a estimulação química do HM, todos os animais foram colocados na arena e a frequência e duração dos comportamentos defensivos, tais como avaliação de risco, rotações, saltos, fuga, alerta, movimento defensivo retrógrado, e não defensivos como levantamentos e cruzamentos foram registrados. Tais procedimentos reduziram a magnitude do comportamento de fuga orientada, sugerindo que a elaboração da resposta de defesa eliciada pelo bloqueio de receptores GABAA no HM pode recrutar conexões entre o hipotálamo e a coluna dorsal da SCP, as quais podem estar mediadas por peptídeos opioides endógenos com recrutamento de receptores opioides $\mu_{1}$ e $\kappa$. 


\title{
EFEITOS DE DIFERENTES DOSES DE DOXICICLINA SOBRE AS ALTERAÇÕES VASCULARES ASSOCIADAS À HIPERTENSÃO EXPERIMENTAL 2R1C
}

\author{
Danielle Aparecida Guimarães
}

Orientador: Prof. Dr. José Eduardo Tanus dos Santos

Dissertação de Mestrado apresentada em 27/10/2010

A hipertensão arterial provoca alterações vasculares que estão associadas com o aumento da atividade das metaloproteinases (MMPs). Embora estas alterações possam ser atenuadas pela doxiciclina, um inibidor não seletivo de MMPs, nenhum estudo anterior avaliou o efeito de diferentes doses de doxiciclina sobre estas alterações. No presente trabalho estudamos os efeitos da doxiciclina nas doses de 3,10 e $30 \mathrm{mg} / \mathrm{kg} /$ dia sobre as alterações vasculares encontradas no modelo de hipertensão renal 2 rins-1 clipe (2R1C). A pressão arterial sistólica (PAS) foi monitorada durante as quatro semanas de tratamento com a doxiciclina. Anéis de aorta foram isolados para avaliar o relaxamento dependente do endotélio. Morfometria quantitativa das mudanças estruturais na parede da aorta foram estudadas através de cortes histológicos corados com hematoxilina/eosina. Os níveis aórticos de MMP-2 e a atividade proteolítica foram determinados por zimografia em gel e in situ, respectivamente. O tratamento com doxiciclina nas três diferentes doses apresentou efeito hipotensor, ao reduzir de forma significativa a PAS dos animais 2R1C tratados com doxiciclina em relação aos animais 2R1C tratados com veículo $(195,4 \pm 3,9 \mathrm{mmHg}$ versus $177,2 \pm 6,2 \mathrm{mmHg}, 176,3 \pm 4,5 \mathrm{mmHg}$ e $173 \pm 5,1 \mathrm{mmHg}$ nos ratos hipertensos $2 \mathrm{R} 1 \mathrm{C}$ tratados com veículo, ou com doxiciclina, $3,10,30 \mathrm{mg} / \mathrm{kg} / \mathrm{dia}$, respectivamente $(\mathrm{P}<0,01))$. No entanto, apenas a maior dose de doxiciclina normalizou a resposta relaxante da ACh $(\mathrm{P}<0,05)$, a hipertrofia vascular e o aumento dos níveis da MMP-2 induzidos pela hipertensão 2R1C (P <0,05). Não foram observadas mudanças significativas entre os animais controle (Sham+veículo, Sham+doxi 3, Sham+doxi 10, Sham+doxi 30) em relação a todos os parâmetros estudados. Em conclusão, estes resultados sugerem que a doxiciclina diminui a atividade da MMP-2, melhorando assim a disfunção endotelial, e o remodelamento vascular encontrados nesse modelo de hipertensão renovascular. Além disso, menores doses de doxiciclina não atenuam estas alterações vasculares.

\section{EFEITO DA INIBIÇÃO DAS METALOPROTEINASES DA MATRIZ EXTRACELULAR E DO TRATAMENTO COM ANTIOXIDANTES SOBRE AS ALTERAÇÕES CARDÍACAS DECORRENTES DA HIPERTENSÃO RENOVASCULAR}

\author{
Élen Rizzi Sanchez \\ Orientadora: Profa. Dra. Raquel Fernanda Gerlach \\ Tese de Doutorado apresentada em 22/11/2010
}

A hipertensão arterial sistêmica (HAS) é frequentemente acompanhada por hipertrofia ventricular esquerda (HVE) que contribui para as altas taxas de mortalidade por doenças cardiovasculares associadas à HAS. As metaloproteinases da matriz extracelular (MMPs), enzimas que degradam constituintes da matriz, estão aumentadas no miocárdio em diversos modelos experimentais de HVE, incluindo HAS. Recentemente, foi mostrado que a MMP-2 pode ser uma das principais proteases envolvidas nas alterações morfológicas e funcionais cardíacas. O estresse oxidativo é um dos fatores presentes na HAS e poderia ativar as MMPs devido à ativação da NADPH oxidase em resposta à angiotensina II. Devido ao aumento de angiotensina II e estresse oxidativo observado no modelo experimental 2 rins, 1 clipe (2R1C), estes animais foram escolhidos para a realização deste trabalho. Os objetivos deste trabalho foram (1) Verificar se aumentos nas concentrações e atividade das MMPs (especialmente MMP-2) podem contribuir para as alterações cardíacas associadas à hipertensão renovascular (2R-1C); e (2) verificar se o estresse oxidativo modula as concentrações e atividade da MMP-2 contribuindo para para as alterações cardíacas associadas à hipertensão 2R-1C. Para isso, foi utilizada a doxiciclina, um inibidor não seletivo de MMPs e drogas antioxidantes (tempol e apocinina). A HAS foi acompanhada durante todo o período do estudo por pleitismografia de cauda e no final dos tratamentos, este parâmetro também foi avaliado através de uma análise invasiva. Todos os tratamentos atenuaram os aumentos na pressão arterial nos animais $2 \mathrm{R} 1 \mathrm{C}(\mathrm{P}<0,05)$. Porém, a pressão arterial nos animais 2R1C tratados com doxiciclina ou antioxidantes permanceram elevadas no final do tratamento em comparação com seus respectivos controles $(\mathrm{P}<0,05)$. Os tratamentos com doxiciclina ou antioxidantes atenuaram as disfunções na contratilidade cardíaca nos animais 2R1C, avaliadas através da primeira derivada temporal de pressão ventricular $( \pm \mathrm{dP} / \mathrm{dt}, \mathrm{P}<0,05)$. A HVE foi verificada através de análises morfológicas e de um índice do peso cardíaco. Através destes parâmetros, foi encontrado que os animais 2R1C (sem tratamento) apresentaram HVE com características 
adaptativas. Os tratamentos com doxiciclina e antioxidantes atenuaram a HVE nos animais 2R1C (P<0,05). Além das disfunções morfofuncionais observadas nos animais 2R1C (não tratados), foram encontrados aumentos significativos nas concentrações de MMP-2 no miocárdio detectados por zimografia em gel, bem como por imunomarcação (P<0,05). Estes aumentos ocorreram em paralelo ao aumento na atividade gelatinolítica total observado por zimografia in situ no ventrículo esquerdo dos animais $2 \mathrm{R} 1 \mathrm{C}(\mathrm{P}<0,05)$. Os tratamentos com doxiciclina e antioxidantes não afetaram as concentrações de MMP-2 no miocárdio dos animais $2 \mathrm{R} 1 \mathrm{C}(\mathrm{P}>0,05)$. Porém, estes tratamentos reduziram a atividade gelatinolítica nos animais hipertensos $(\mathrm{P}<0,05)$. Os antioxidantes reduziram o estresse oxidativo presente no miocárdio dos animais $2 \mathrm{R} 1 \mathrm{C}(\mathrm{P}<0,05)$. Em conjunto, nossos resultados sugerem que as MMPs, especialmente a MMP-2, participem das alterações cardíacas associadas à hipertensão 2R1C. Além disso, o estresse oxidativo pode estar relacionado com a ativação das MMPs observada neste modelo de hipertensão.

\title{
EFEITO DA DOXICICLINA NAS ALTERAÇÕES VASCULARES DE RATOS ESPONTANEAMENTE HIPERTENSOS
}

\author{
Raquel Carros Antonio \\ Orientadora: Profa. Dra. Raquel Fernanda Gerlach \\ Dissertação de Mestrado apresentada em 29/11/2010
}

A hipertensão arterial provoca alterações morfológicas e funcionais na vasculatura. Metaloproteinases da matriz extracelular (MMPs) são endopeptidases dependentes de cálcio e zinco que degradam a matriz extracelular, apresentam papel importante em várias doenças cardiovasculares, inclusive na hipertensão. Aumento na atividade das MMPs pode levar à degradação das proteínas da matriz extracelular, contribuindo para alterações nos vasos sanguíneos durante hipertensão. Desta forma, os objetivos deste trabalho foram 1) Comparar a espessura das aortas, a atividade gelatinolítica total, a expressão de MMP-2 e atividade de espécies reativas de oxigênio em SHR e normotensos WKy; 2) Verificar se o tratamento com doxiciclina altera a pressão arterial sistólica em SHR; 3) Verificar se o tratamento com doxiciclina altera a hipertrofia de aortas em SHR; 4) Verificar se o tratamento com doxiciclina altera a atividade gelatinolítica total e a quantidade e/ou atividade de MMP-2 na aorta de SHR; 5) Verificar se o tratamento com doxiciclina altera a atividade de EROs em SHR. Animais nomotensos WKy e SHR foram tratados com o veículo ou doxiciclina (30mg/kg/dia), gavagem, por cinco semanas. A PAS foi monitorada semanalmente por pletismografia de cauda. Após o tratamento, os animais foram sacrificados e a aorta de cada animal foi submetida às seguintes análises: a) análise morfológica incluindo área de secção transversal, razão média/ lúmen e medida dos diâmetros interno e externo; b) dosagem de proteína pelo método de Bradford e zimografia em gel; c) zimografia in situ; d) imunofluorescência para MMP-2 e e) EROs in situ. O tratamento com doxiciclina reduziu a hipertensão arterial $(\mathrm{SHR}=194 \pm 2 \mathrm{mmHg}$ versus $\mathrm{SHR}+\mathrm{Doxi}=166 \pm 1 \mathrm{mmHg} \mathrm{p}<0,05)$. O tratamento com doxiciclina levou à diminuição da atividade gelatinolítica total e EROs na camada média e íntima das aortas, mas não reduziu o remodelamento vascular na aorta dos animais tratados. O conjunto dos nossos resultados indica que a doxiciclina, reduz a PAS, a atividade gelatinolítica, particularmente da MMP-2, no entanto não altera o remodelamento vascular nas aortas de SHR.

\section{EFEITOS DA INIBIÇÃO DA SÍNTESE DE NO SOBRE O PADRÃO DE EXPRESSÃO DA PROTEÍNA FoS NO ENCÉFALO DE RATOS EXPOSTOS A MODELO ANIMAL DE DEPRESSÃO}

\author{
Michelle Silva \\ Orientadora: Profa. Dra. Sâmia Regiane Lourenço Joca \\ Dissertação de Mestrado apresentada em 02/12/2010
}

A Depressão é uma das psicopatologias mais prevalentes e um dos principais fatores que pode desencadear esta condição é o estresse. Vários neurotransmissores têm sido envolvidos na fisiopatologia da depressão, incluindo as monoaminas e, mais recentemente, o glutamato e o óxido nítrico (NO). Nesse sentido, evidências indicam que a administração de inibidores da sintase do NO neuronial (nNOS) induz efeito tipo-antidepressivo em modelos animais, como o teste do nado forçado (FST). Entretanto, os circuitos neurais envolvidos nestes efeitos ainda não foram estudados. Portanto, o presente trabalho investigou as estruturas encefálicas envolvidas no efeito tipo-antidepressivo induzido pela administração sistêmica de um inibidor preferencial da nNOS, o 7-nitroindazole (7NI), comparando-o com os antidepressivos 
clássicos venlafaxina (VLF) e fluoxetina (FLX). Para tanto, foi analisado o padrão de expressão da proteína Fos, um marcador de atividade neuronial, no encéfalo de animais tratados e submetidos ao FST. Os resultados evidenciaram que o 7-NI, assim como a VLF e FLX promoveu efeito tipo-antidepressivo no modelo do nado forçado, evidenciado através da diminuição do tempo de imobilidade dos animais durante o teste. Esses efeitos foram acompanhados de redução na expressão da proteína Fos em diversas estruturas encefálicas, tais como córtex pré-frontal medial, núcleos da rafe (dorsal e mediano), hipotálamo, núcleo acumbens, amídala, substância cinzenta periaquedutal, locus coeruleus, entre outros. O conjunto de dados sugere que o efeito tipo-antidepressivo induzido pelos inibidores da NOS envolveria substratos neurobiológicos que são comuns aos antidepressivos convencionais e dá maior sustentação à participação do NO na neurobiologia da depressão.

\title{
EFEITOS DE POLIMORFISMOS GENÉTICOS DA INOS SOBRE A SUSCEPTIBILIDADE A DOENÇAS HIPERTENSIVAS GESTACIONAIS
}

\author{
Lorena Machado Amaral
}

Orientador: Prof. Dr. José Eduardo Tanus dos Santos

Dissertação de Mestrado apresentada em 08/12/2010

A pré-eclâmpsia (PE) é uma síndrome específica da gravidez caracterizada pela hipertensão e proteinúria após 20 semanas gestacionais. Afeta 3-5\% das gestações no mundo e é a principal responsável pelos partos prematuros, morbidade e mortalidade neonatal. A fisiopatologia da PE não está completamente elucidada e deficiência na formação de óxido nítrico (NO) tem sido relacionada com desordens hipertensivas gestacionais. O objetivo deste trabalho foi verificar se dois polimorfimos da iNOS (NOS2A), C-1026A e S608L, e os haplótipos estão associados com PE/HAG. Estudamos 565 gestantes: 212 gestantes saudáveis (GS), 166 gestantes com hipertensão gestacional (HAG) e 187 gestantes com pré-eclâmpsia (PE). DNA genômico foi extraído através do sangue total e os genótipos dos polimofirmos C-1026A e S608L foram determinados por Real-Time PCR, utilizando Taqman ${ }^{\circledR}$ Allele Discrimination assay. Os haplótipos foram inferidos através do programa PHASE 2.1. Em relação ao polimorfismo C-1026A, nenhuma diferença estatística significativa foi evidenciada nas distribuições genotípicas e alélicas ao comparar PE ou HAG com o grupo das gestantes saudáveis. Entretanto, as frequências genotípicas e alélicas do polimorfismo S608L foram diferentes no grupo PE em comparação ao grupo GS. O genótipo GA e o alelo A foram mais comumente encontrados nas gestantes com PE. Nenhuma diferença significativa foi encontrada em relação às distribuições genotípicas e alélicas do grupo HAG comparado com o grupo GS. Esses resultados sugerem que o polimorfimo S608L do gene da iNOS está associado com PE, mas não com HAG. Nossos estudos sugerem que a iNOS pode estar envolvida na patogênese da pré-eclâmpsia, mas não na hipertensão arterial gestacional.

\section{ENVOLVIMENTO DA NEUROTRANSMISSÃO NORADRENÉRGICA DO CÓRTEX PRÉ-FRONTAL LATERAL NA MODULAÇÃO DO SISTEMA CARDIOVASCULAR EM RATOS}

\author{
Fernando Henrique Ferrari Alves \\ Orientador: Prof. Dr. Fernando Morgan de Aguiar Corrêa \\ Tese de Doutorado apresentada em 09/12/2010
}

O córtex pré-frontal lateral (CPFL) é uma estrutura encefálica envolvida no controle do sistema cardiovascular. Respostas cardiovasculares foram relatadas após estimulação elétrica ou química do CPFL. As respostas têm como substrato neural suas conexões com estruturas envolvidas no controle da atividade cardiovascular, tais como o núcleo dorsal do vago (NDV) e o núcleo do trato solitário (NTS). Dentre os neurotransmissores presentes no CPFL, a noradrenalina (NA) aparece como possível moduladora do sistema cardiovascular. Estudos prévios já demonstraram a participação do sistema noradrenérgico presente no CPFL na modulação da atividade cardiovascular durante situações comportamentais. No presente estudo nós observamos que a microinjeção de NA no CPFL de ratos não anestesiados causou respostas pressoras e bradicárdicas de maneira dose-dependente, sendo que tais respostas foram bloqueadas pelo pré-tratamento do CPFL com WB4101 ( $15 \mathrm{nmol} / 100 \mathrm{~nL}$ ) ou 5-metil-urapidil ( $15 \mathrm{nmol} / 100 \mathrm{~nL})$, antagonistas seletivos de adrenoceptores $\alpha_{1}$. Todavia, o pré-tratamento com antagonista de receptores $\alpha_{2}$ RX821002 $(15 \mathrm{nmol} / 100 \mathrm{~nL})$ ou o pré-tratamento com antago- 
nista não seletivo de adrenoceptores $\beta$, propranolol (15 nmol/100nL), não alterou as respostas cardiovasculares causadas pela microinjeção de NA no CPFL. Esses dados nos sugerem que os adrenoceptores do subtipo $\alpha_{1}$, presentes no CPFL, medeiam as respostas cardiovasculares à microinjeção local de NA. O pré-tratamento sistêmico com o bloqueador ganglionar pentolínio $(5 \mathrm{mg} / \mathrm{kg})$ potencializou a resposta pressora à microinjeção de NA no CPFL, sendo que o pré-tratamento com $\operatorname{dTir}\left(\mathrm{CH}_{2}\right)_{5}(\mathrm{Me}) \mathrm{AVP}(50 \mu \mathrm{g} / \mathrm{kg})$, um antagonista de receptores vasopressinérgicos $\mathrm{V}_{1}$, foi capaz de bloquear tanto o aumento da pressão arterial (PA) quanto a queda na frequência cardíaca (FC) causada pela microinjeção de NA no CPFL. Assim, estes dados sugerem que as respostas cardiovasculares decorrentes da microinjeção de NA no CPFL são mediadas pela liberação do hormônio vasopressina na circulação sistêmica. Nós também estudamos o envolvimento da neurotransmissão noradrenérgica do CPFL na modulação da resposta bradicárdica do barorreflexo. A microinjeção bilateral no CPFL do WB4101 (15 nmol/100nL) causou um aumento no ganho da resposta bradicárdica reflexa decorrente de aumentos da pressão arterial (PA) induzida pela infusão intravenosa de fenilefrina, o que sugere que a ativação de adrenoceptores $\alpha_{1}$ no CPFL tem uma influência inibitória sobre a resposta bradicárdica do barorreflexo. Microinjeção bilateral no CPFL do RX821002 (15 nmol/100nL) ou de propranolol (15 nmol/100nL) não afetou a atividade do barorreflexo. Entretanto, a infusão de NA no CPFL durante a estimulação do barorreflexo causou repostas inversas àquelas encontradas com a microinjeção do antagonista de adrenoceptores $\alpha_{1}$ WB4101 e além disso, esse efeito da infusão de NA foi bloqueado pelo pré-tratamento com WB4101, o que mostra que, de fato, a neurotransmissão noradrenérgica no CPFL participa da modulação da atividade do barorreflexo. Por fim, investigamos o envolvimento da neurotransmissão noradrenérgica do CPFL nas respostas cardiovasculares durante o estresse por restrição. Foi observado que a administração bilateral de $\mathrm{CoCl}_{2}$ ou de doses crescentes de WB4101 no CPFL, reduziu a reposta pressora e taquicárdica causada pelo estresse por restrição. Além disso, o pré-tratamento do CPFL com RX821002 reduziu significantemente a resposta pressora sem alterar a resposta taquicárdica durante o estresse por restrição. O pré-tratamento do CPFL com propranolol não alterou significantemente as respostas cardiovasculares ao estresse por restrição. Esses dados sugerem que a neurotransmissão noradrenérgica no CPFL participa da regulação da atividade cardiovascular durante situações de estresse e que os diferentes tipos de adrenoceptores $\alpha_{1}$ e $\alpha_{2}$ participam nessa modulação.

\section{ESTUDO NEUROANATÔMICO E NEUROFARMACOLÓGICO DOS CÓRTICES RETROESPLÊNIO E OCCIPITAL E SUAS CONEXÕES COM VIAS OPIÓIDES E SEROTONINÉRGICAS NO NÚCLEO PRETECTAL ANTERIOR EM RATOS}

\section{Gláucia de Melo Reis}

Orientador: Prof. Dr. Wiliam Alves do Prado

Tese de Doutorado apresentada em 10/12/2010

A participação do córtex cerebral na modulação da nocicepção tem sido alvo de vários estudos. Estudos prévios demonstraram que a estimulação elétrica (EE) do córtex retroesplênio (CRE) ou occipital (CO) induz antinocicepção em modelos de dor fásica e persistente efeito que, ao menos em parte, depende da participação do núcleo pretectal anterior (NPtA) como estação intermediária da via descendente inibitória utilizada por esses córtices. Assim, o presente estudo investigou as conexões neuroanatômicas do CRE ou CO envolvidas na modulação da nocicepção por meio da microinjeção de BDA conjugado ao Texas red nestes córtices. Avaliou-se, também os neurotransmissores envolvidos nestas interconexões através da microinjeção de antagonistas seletivos opióides (naloxonazine) ou serotoninérgicos (metiotepina ou ketanserina) nas estruturas encefálicas marcadas com o neurotraçador. Por fim, este estudo investigou os neurotransmissores recrutados no CRE e CO para induzir antinocepção avaliada pelo teste de retirada da cauda (TRC). No presente estudo foram observadas conexões do CRE com porções dorsal e ventral do NPtA, tálamo submédio (Sb), CO e córtex cingulado anterior (CCA), assim como as conexões do CO com NPtA dorsal, CRE e colículo superior (CS). O pré-tratamento do NPtA dorsal com cloreto de cobalto $\left(\mathrm{CoCl}_{2}\right)$, naloxonazina ou metiotepina reduziu a duração e a intensidade da resposta à EE do CRE. O bloqueio neural do Sb reduziu a intensidade, mas não a duração do efeito antinociceptivo, ao passo que a inibição do CCA aumentou a duração do efeito. Já o pré-tratamento do NPtA com $\mathrm{CoCl}_{2}$ ou metiotepina reduziu a duração do efeito produzido por EE do CO enquanto o bloqueio neural ou microinjeção de naloxonazina no CS reduziu a intensidade e a duração deste efeito. Esses resultados nos levaram a concluir que: (1) A antinocicepção organizada pelo CRE depende da ativação de terminais glutamatérgicos e opióides no CRE que ativam duas vias descendentes inibitórias distintas: do CRE para o NPtA dorsal ou ventral (via receptores m1-opióides e 5-HT ) e do CRE para o Sb(via receptores $\mu 1$ opióides); (2) Simultaneamente, o CRE parece ser modulado negativamente pelo CCA e, (3) além disso, terminais glutama-

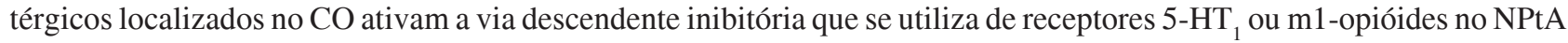
e o CS, respectivamente. 


\title{
MEDIAÇÃO DA RESPOSTA FEBRIL INDUZIDA PELA INJEÇÃO DE Staphylococcus aureus EM RATOS
}

\author{
Juliano Manvailer Martins \\ Orientadora: Profa. Dra. Glória Emília Petto Souza \\ Tese de Doutorado apresentada em 15/12/2010
}

Vários estudos demonstram que a parede celular de Staphylococcus aureus (S.aureus), bem como as suas toxinas induzem febre em várias espécies. Além disso, estudo realizado em nosso laboratório demonstrou que a injeção intraperitoneal (i.p.) de S. aureus vivo, na dose de $10^{13} \mathrm{UFC} /$ cavidade, induz resposta febril em ratos. Entretanto, esta resposta frente à infecção por $S$. aureus ainda não foi caracterizada. Assim, o presente estudo investigou a mediação da resposta febril induzida pela injeção sistêmica de S. aureus vivo (ATCC 25923) em ratos. A injeção i.p. de S. aureus $\left(10^{10}\right.$ ou $2 \times 10^{10} \mathrm{UFC} /$ cavidade) induziu um aumento significativo da temperatura corporal de longa duração. A dose efetiva de $10^{10}$ UFC / cavidade foi escolhida para os demais experimentos. $\mathrm{O}$ aumento da temperatura corporal induzido por esta bactéria constitui febre e não hipertermia, pois foi acompanhado de redução da temperatura da pele da cauda dos animais, indicativo de vasoconstrição periférica, bem como de redução do índice de perda de calor (IPC). A febre produzida pelo $S$. aureus foi inibida pelo pré-tratamento com celecoxibe $(2,5 \mathrm{mg} / \mathrm{kg}$; p.o., $30 \mathrm{~min}$ antes) e apenas reduzida pelo pré-tratamento com dipirona ( $120 \mathrm{mg} / \mathrm{kg}$, i.p., $30 \mathrm{~min}$ antes). Por outro lado, a indometacina ( $2,0 \mathrm{mg} / \mathrm{kg}$, ip, $30 \mathrm{~min}$ antes) não foi capaz de alterar a febre induzida por esta bactéria. Nesse sentido, verificou-se também que o $S$. aureus induziu um aumento dos níveis de $\mathrm{PGE}_{2}$ no CSF e no hipotálamo, os quais foram reduzidos pelo pré-tratamento com celecoxibe ou indometacina. Diferentemente, a dipirona reduziu os níveis deste prostanóide somente no CSF, não alterando os do hipotálamo. Além disso, foi demonstrado que a febre induzida pelo $S$. aureus foi reduzida pelo pré-tratamento com anti-MIP-1 $\alpha$ (i.c.v.) e met-RANTES (i.v.) e também pelo pós-tratamento com DALBK (i.c.v.), não sendo alterada pelo pré-tratamento i.c.v. com anti-IL6, IL-1ra, rsTNF, anti-CINC, BQ-123, BQ-788, $\alpha$-helical $\mathrm{CRF}_{9-41}$ e DALBK. Verificamos também que o $S$. aureus induz aumento significativo, dependente do tempo, dos níveis da quimiocina RANTES no exsudato peritoneal. Estes resultados fornecem a primeira descrição da febre experimental induzida pela inoculação de $S$. aureus vivo em ratos, que se mostrou suscetível ao celecoxibe e à dipirona, mas não à indometacina. Estes dados, juntamente com os resultados que evidenciam a participação das quimiocinas RANTES e MIP- $1 \alpha$ e da BK por receptores do tipo $\mathrm{B}_{1}$ na resposta febril induzida pelo $S$. aureus $\left(10^{10} \mathrm{UFC}\right.$ / cavidade) demonstram que esta resposta apresenta uma via dependente da síntese de $\mathrm{PGE}_{2}$ e outra independente de $\mathrm{PGE}_{2}$.

\section{EFEITO VASODILATADOR INDUZIDO PELAS FORMAS ESTÁVEIS DE COMPLEXOS DE RUTÊNIO DOADORES DE ÓXIDO NÍTRICO}

\section{Gerson Jhonatan Rodrigues}

Orientadora: Profa. Dra. Lusiane Maria Bendhack

Tese de Doutorado apresentada em 20/12/2010

Vários efeitos biológicos têm sido descritos para o óxido nítrico (NO), entre eles, o efeito vasodilatador e a modulação do processo de angiogênese. O nosso trabalho teve por objetivo estudar os mecanismos envolvidos na vasodilatação induzida pelos complexos de rutênio cis-[Ru(H-dcbpy $\left.)_{2}(\mathrm{Cl})(\mathrm{NO})\right](\mathrm{DCBPY})$ e $c i s-\left[\mathrm{Ru}(\mathrm{bpy})_{2}\left(\mathrm{NO}_{2}^{-}\right)(\mathrm{NO})\right]$. $\left(\mathrm{PF}_{6}\right)_{2}(\mathrm{BPY})$, em suas conformações estáveis. Em condições fisiológicas $\left(p \mathrm{H} 7,4\right.$ e temperatura $\left.37^{\circ} \mathrm{C}\right)$ os compostos DCBPY e BPY não são estáveis na forma $c i s-\left[\mathrm{Ru}(\mathrm{H}-\mathrm{dcbpy})_{2}(\mathrm{Cl})(\mathrm{NO})\right]$ e $c i s-\left[\mathrm{Ru}(\mathrm{bpy})_{2}\left(\mathrm{NO}_{2}{ }^{-}\right)(\mathrm{NO})\right](\mathrm{Ru}-\mathrm{NO})$, mas sim na forma $c i s-\left[\mathrm{Ru}\left(\mathrm{H}^{-}\right.\right.$ dcbpy $\left.\left.^{-}\right)_{2}(\mathrm{Cl})\left(\mathrm{NO}_{2}^{-}\right)\right]$e cis-[Ru(bpy $\left.)_{2}\left(\mathrm{NO}_{2}^{-}\right)\left(\mathrm{NO}_{2}^{-}\right)\right]\left(\mathrm{Ru}_{-} \mathrm{NO}_{2}^{-}\right)$. Na conformação estável, os compostos DCBPY e BPY induziram relaxamento vascular em aortas isoladas de ratos, pré-contraídas com fenilefrina, com a seguinte ordem de potência: nitroprussiato de sódio (NPS) > BPY > DCBPY > nitrito de sódio (NITRITO). Entretanto, todos os compostos apresentaram efeito máximo semelhante e as curvas concentração-efeito apresentaram paralelismo. O DCBPY e o BPY apresentaram efeito mais lento em induzir relaxamento, comparado ao NPS e NITRITO, que apresentaram tempos de relaxamento semelhantes. Os compostos DCBPY, BPY e o NITRITO formam, principalmente, a espécie de $\mathrm{NO}$ radicalar $\left(\mathrm{NO}^{\circ}\right)$, enquanto que o DCBPY e BPY formam em parte, íon nitroxil ( $\mathrm{NO}^{-}$) e o NITRITO não forma NO-. O relaxamento induzido por DCBPY, BPY e NITRITO caracteriza-se pela ativação da enzima guanilil-ciclase solúvel (GCs). O DCBPY forma NO no meio extracelular, o BPY forma NO no meio intracelular e extracelular e o NITRITO somente no meio intracelular. Nossos resultados indicam que o DCBPY possui atividade cíclica de liberação de NO em aortas, podendo converter nitrito a NO. Porém, não verificamos atividade cíclica de liberação de NO para o composto BPY. A forma "áquo" do composto BPY $\left(\right.$ cis- $\left.\left[\mathrm{Ru}(\mathrm{bpy})_{2}(\mathrm{Cl})\left(\mathrm{H}_{2} \mathrm{O}\right)\right]^{+}\right)$, 
apresentou efeito vasodilatador somente em aortas contraídas com fenilefrina, sugerindo uma possível ação antagonista do receptor $\alpha_{1}$-adrenérgico. Em células do músculo liso vascular verificamos que os compostos DCBPY, BPY, NPS e NITRITO promoveram aumento da concentração citosólica de NO ([NO]c) e queda na concentração citosólica de Ca ${ }^{2+}$ $\left(\left[\mathrm{Ca}^{2+}\right] \mathrm{c}\right)$. Em concentrações equieficazes, o aumento da $[\mathrm{NO}] \mathrm{c}$ e queda da $\left[\mathrm{Ca}^{2+}\right] \mathrm{c}$ foram semelhantes entre os compostos DCBPY, BPY e NPS e menor para o NITRITO. Estes resultados sugerem que os compostos DCBPY, BPY e NPS liberam maior $[\mathrm{NO}] \mathrm{c}$ e por isso induzem maior queda na $\left[\mathrm{Ca}^{2+}\right] \mathrm{c}$, quando comparados ao NITRITO. Verificamos que além de liberar NO, o composto DCBPY também pode atuar como sequestrador de NO. Quando o composto DCBPY é reduzido pela glutationa ou ácido ascórbico, ocorre a liberação de nitrito e o composto sequestra NO. O composto DCBPY também tem ação antioxidante. O processo de angiogênese é inibido pelo composto DCBPY, sendo este efeito atribuído às suas atividades como sequestrador de $\mathrm{NO}$ e antioxidante. Em conjunto, nossos resultados indicam que os compostos DCBPY e BPY mantêm-se na forma estável ( $\mathrm{Ru}-\mathrm{NO} 2^{-}$) em condições fisiológicas ( $\mathrm{pH} \mathrm{7,4} \mathrm{e} \mathrm{temperatura} 37^{\circ} \mathrm{C}$ ) e que induzem relaxamento vascular em aorta de ratos pela formação de $\mathrm{NO}^{\circ}$ e ativação da via GCs- GMPc. Além disso, o composto DCBPY apresenta atividade cíclica de formação de NO e sob redução química, pode atuar como sequestrador de NO e controlar a $[\mathrm{NO}] \mathrm{c}$.

\title{
PAPEL DO RECEPTOR toll-like 9 NA FALÊNCIA DE MIGRAÇÃO DOS NEUTRÓFILOS NA SEPSE
}

\author{
Silvia Cellone Trevelin \\ Orientador: Prof. Dr. José Carlos Alves Filho \\ Dissertação de Mestrado apresentada em 20/12/2010
}

O recrutamento de neutrófilos para o sítio da infecção é um evento crucial para o combate aos microrganismos e sobrevivência na sepse. A migração destes polimorfonucleares é dirigida através de um gradiente quimiotático por meio do reconhecimento de quimiocinas por receptores acoplados a proteína G (GPCRs), os quais são regulados por quinases específicas (GRKs). Estudos prévios demonstraram que na sepse ocorre uma falência na migração de neutrófilos para o foco infeccioso em função da dessensibilização de receptores quimiotáticos via GRKs induzida pela ativação de receptores tolllike (TLRs), TLR2 e TLR4. Apesar de a ausência de TLR9 em células dendriticas ter sido relacionada a maior sobrevivência de camundongos sépticos, o papel de TLR9 atuando diretamente em neutrófilos não foi avaliado. Objetivando preencher esta lacuna, propôs-se avaliar o papel direto de TLR9 na falência de migração de neutrófilos na sepse. Os camundongos TLR9-/- apresentaram maior sobrevivência a sepse polimicrobiana avaliada por meio do modelo de ligadura e perfuração do ceco (CLP). A deficiência de TLR9 também acarretou em aumento na migração de neutrófilos para o foco da infecção, menor sequestro de neutrófilos no pulmão, bem como, menor número de bactérias no lavado peritoneal e sangue. A ativação de TLR9 por oligodeoxinucleotídeo contendo o dinucleotídeo CpG não metilado (ODN CpG) nos neutrófilos reduziu a quimiotaxia destes em direção a quimiocina CXCL2 e expressão do receptor quimiotático CXCR2. Além disso, neutrófilos estimulados com ODN CpG apresentaram aumento na expressão da quinase tipo 2 relacionada a receptores acoplados a proteína G (GRK2). Dessa forma, a ativação de TLR9 em neutrófilos circulantes no sangue é prejudicial na sepse por reduzir a quimiotaxia destes para o foco da infecção ao induzir a dessensibilização de CXCR2 via GRK2.

\section{Fisiologia}

\section{EFEITOS DE ESTRÓGENO E DE PROGESTERONA NA ATIVIDADE BASAL DO EIXO HIPOTÁLAMO HIPÓFISE ADRENAL}

\author{
Luana Maria Silva Alves \\ Orientador: Prof.Dr. Celso Rodrigues Franci \\ Dissertação de Mestrado apresentada em 04/10/2010
}

Há evidencias de interação bidirecional dos eixos HPA e HPG envolvendo diferentes estruturas, entretanto, os mecanismos envolvidos são pouco compreendidos. Situações de estresse podem alterar a função reprodutiva, e hormônios 
gonadais podem modificar a resposta de estresse. O objetivo deste trabalho foi verificar se estrógeno (E2) e progesterona (P4) modificam a atividade basal do eixo hipotálamo-hipófise-adrenal (HPA), analisada pelas secreções de corticosterona (CORT) e de P4 e pelas expressões de receptores para corticosteróides (mineralocorticóides, MR e glicocorticóides, GR) em sítios cerebrais de retroalimentação do eixo HPA. Ratas Wistar adultas foram mantidas em ciclo claro-escuro de $12 \mathrm{~h}$ e acesso livre à ração e água. $\mathrm{O}$ ciclo estral foi monitorado por esfregaço vaginal e a determinação da secreção de hormônio luteinizante (LH) foi realizada para confirmação do proestro. Seis amostras de sangue foram coletadas através de cateter na jugular, durante a tarde (13-18h), dos seguintes grupos de ratas: ovariectomizadas (OVX); controles em proestro; tratadas com antagonista de E2 (tamoxifen) ou de P4 (RU486), ou ambos; tratadas com os respectivos veículos dos antagonistas. O plasma foi separado e estocado para dosagens hormonais por radioimunoensaio. Após a última coleta de sangue, os animais foram anestesiados e perfundidos para remoção dos cérebros, que foram manipulados para verificação por imunofluorescência, da expressão de MR e de GR na região CA1 e no subículo do hipocampo ventral, e de GR no núcleo paraventricular (PVN). Os resultados mostram que: a secreção de LH confirmou a fase de proestro; a secreção basal de CORT não foi alterada pelas manipulações de injeções nem pela remoção dos ovários; ocorreu pico de secreção de CORT e de P4 às 14h em todos os grupos experimentais; os antagonistas de E2 e de P4 não alteraram a secreção total de CORT, porém o RU486 aumentou (às 13 e 15h) e o tamoxifen reduziu (às 15h) a concentração de CORT; um segundo pico de secreção de P4 no final da tarde (17-18h) foi bloqueado pela ovariectomia e por Tamoxifen, e amplificado por RU486; o segundo pico de P4 também não ocorreu em ratas tratadas com Tamoxifen e RU486; não houve alteração do número de neurônios com expressão de GR e MR na região CA1 e no subículo do hipocampo ventral nem de GR no PVN. Em conclusão, nossos resultados indicam que: E2 e P4 podem exercer efeitos antagônicos sobre a secreção basal de CORT, respectivamente estimulatório e inibitório; os picos de secreção de $\mathrm{P} 4$ têm origens diferentes, o primeiro (14h) da adrenal e o segundo (17-18h) do ovário; E2 estimula a secreção ovariana de P4 na tarde de proestro; E2 e P4 não alteram o número de neurônios que expressam GR e MR em sítios de retroalimentação do eixo HPA, mas não se pode descartar que alterem a atividade desses neurônios.

\title{
AÇÃO DE MONOAMINAS SOBRE A FOSFORILAÇÃO DE PROTEÍNAS ENVOLVIDAS NA SINALIZAÇÃO DO RECEPTOR TRKB EM UM MODELO EXPERIMENTAL DE DOR NEUROPÁTICA
}

\author{
Adriano Cardozo Franciosi
}

Orientador: Prof. Dr. Guilherme A. Lucas

Dissertação de Mestrado apresentada em 26/10/2010

O fator neurotrófico BDNF está envolvido em diversos mecanismos de aumento da eficiência sináptica, incluindo a sensibilização central. A sinalização pelo de seu receptor preferencial, TrkB, é feita por três vias principais: PLC $\gamma-1$, SHC e PI3K. Quando fosforilado, PLC $\gamma-1$ torna-se ativo e aumenta a concentração de cálcio intracelular desencadeada por mecanismos dependentes de IP3 e DAG. SHC e PI3K redundantemente levam a ativação de Akt através de fosforilação. Coletivamente estas proteínas podem ativar o fator de transcrição CREB. CREB desempenha um papel fundamental sobre as características neuroplásticas de BDNF associadas aos mecanismos subjacentes à dor neuropática. Camundongos da linhagem Balb / C foram submetidos à ligadura parcial do nervo isquiática (PSL), como descrito por Seltzer. O desenvolvimento da hipersensibilidade mecânica foi avaliada com monofilamentos, tal como proposto por Chaplan. No $7^{\circ}$ dia os animais foram selecionados e agrupados como segue: Controle e PSL tratados com veículo, e Controle e PSL tratados com imipramina (30 mg / kg). Extratos do corno dorsal da medula espinhal foram obtidos após os tratamentos agudo (30 min.) e crônico (21 dias). A fosforilação de proteínas específicas foi avaliada por western blot e quantificada por densidade óptica. Os animais lesados desenvolveram alodinia mecânica que foi revertida pelo tratamento crônico com imipramina. A fosforilação de CREB foi significativamente aumentada do $7^{\circ}$ ao $28^{\circ}$ dias após a lesão e apenas o tratamento crônico foi capaz de restaurar os níveis basais. O aumento da fosforilação de Akt no grupo PSL ocorreu apenas no $28^{\circ}$ dia após a lesão, o tratamento com imipramina levou ao aumento na fosforilação de Akt no grupo PSL, tanto aguda como cronicamente. A fosforilação de PLC $\gamma-1$ manteve-se inalterada, exceto pela diminuição observada no grupo Controle submetido ao tratamento agudo com imipramina. Os antidepressivos, como a imipramina, têm sido utilizados para tratar a dor neuropática de diversas etiologias. Apesar de sua conhecida ação como um inibidor da recaptação da monoaminas, seu mecanismo analgésico contra a dor neuropática não é totalmente compreendido. A latência para alcançar os efeitos sugere um envolvimento em processos transcricionais. De fato, nossos dados mostram que o tratamento crônico, mas não agudo, 
diminuiu a fosforilação de CREB. Curiosamente, tal como os nossos resultados também sugerem, este evento não parece estar ligado à diminuição na atividade das vias de PLC $\gamma$-1 e Akt. Embora nossos dados de fosforilação de Akt reforcem a hipótese de uma ativação cruzada entre os receptores TrkB e $\beta$-adrenérgicos, em conjunto nossos dados sugerem que deve existir outro ponto de interação nas cascatas de sinalização, que seja inibida pelo tratamento com imipramina.

\title{
AÇÃO DA PROTEÍNA-QUINASE ATIVADA POR RNA NA NEUROBIOLOGIA DA DOR CRÔNICA DE ORIGEM INFLAMATÓRIA
}

\author{
Elaine Flamia Toniolo \\ Orientador: Prof. Dr. Guilherme A. Lucas \\ Dissertação de Mestrado apresentada em 26/10/2010
}

A proteína-quinase ativada por RNA de fita dupla (PKR) é uma proteína quinase que foi caracterizada por induzir a síntese de interferon do tipo I (IFN), tem um papel importante na regulação na translação, transcrição, e transdução do sinal em inúmeras vias. PKR pode ser ativada por muitos fatores como estímulos inflamatórios, fatores de crescimento, citocinas e estresse oxidativo.

Este trabalho teve como objetivos (1) identificar o perfil de expressão do RNAm e da proteína PKR e na coluna dorsal da medula espinal durante processo inflamatório crônico, (2) monitorar o efeito da inibição de PKR na medula espinal sobre as alterações de sensibilidade induzidas por doença inflamatória crônica e (3) investigar o efeito da inibição de PKR sobre a fosforilação das proteínas p38, p42/44 e JNK na coluna dorsal da medula espinal durante processo inflamatório crônico. Observamos que o RNAm para PKR está presente em células, tanto do gânglio da raiz dorsal, quanto na coluna dorsal da medula espinal e seu perfil de expressão e sua atividade aumentaram durante processo inflamatório crônico. A administração subcutânea de CFA induziu alodínia mecânica e hipernocicepção térmica ipsilateral a injeção sendo que a administração intratecal do inibidor de PKR $(5 \mu \mathrm{M} / 10 \mu \mathrm{L})$ reverteu esta hipernocicepção, mas não teve efeito sobre a alodínia mecânica. Além disso, animais PKR+/- injetados com CFA apresentaram uma redução na hipernocicepção térmica quando comparados aos camundongos $\mathrm{PKR}+/+$. Nossos resultados indicam, ainda, que a atividade pró-nociceptiva de PKR está associada a um aumento da fosforilação das MAPKs p38 e JNK, mas não de p42/44, na coluna dorsal da medula espinal. Juntos estes resultados indicam haver um potencial terapêutico antinociceptivo para compostos que sejam capazes de inibir ou reduzir a atividade de PKR na medula espinal.

\section{EFEITOS DO 17_-ESTRADIOL SOBRE A EXCITABILIDADE NEURONAL DO NIDOPÁLIO CAUDOMEDIAL (NCM) DE ZEBRA FINCHES}

\author{
Thiago Fernando Beckhauser Rodrigues \\ Orientador: Prof. Dr. Ricardo Maurício Xavier Leão \\ Dissertação de Mestrado apresentada em 18/11/2010
}

Além de suas conhecidas ações como hormônios, os esteróides sexuais tem mostrado agir como moduladores da atividade elétrica de muitos neurônios centrais. Eles podem agir tanto por meio de seus bem conhecidos receptores nucleares afetando a transcrição gênica e resultando em mudanças a longo-prazo da fisiologia neuronal ou, pela via não tradicional, mediada por ações rápidas (segundos a minutos) que certamente envolvem receptores de membrana. Esta via rápida de ação dos esteróides no cérebro resulta na regulação do potencial de membrana (Em) e da neurotransmissão por meio da modulação de canais iônicos e receptores para neurotransmissores. Desta forma, os esteróides podem influenciar o comportamento animal em segundos a minutos. É conhecido a mais de três décadas que o cérebro é um sitio de produção de estrógenos pela aromatização da testosterona (T) e que a produção local de estrógenos na área pré-óptica (POA) pode desencadear comportamentos sexuais em uma grande variedade de espécies de vertebrados. Os níveis de aromatase (AROM) cerebral podem ser aumentados pela $\mathrm{T}$ e sua atividade rapidamente regulada pela fosforilação de proteínas e atividade sináptica. Esta produção local de estrógenos no cérebro é crucial para gerar as altas concentrações necessárias para induzir os efeitos rápidos de membrana vistos nos neurônios centrais. O sistema nervoso central (SNC) das aves canoras (ordem passeriforme, subordem oscine) é profundamente influenciado pelos níveis dos hormônios sexuais. Tem 
sido demonstrado há muito tempo a notável influência dos andrógenos e estrógenos sobre o sistema neural do canto e, desde então, as aves canoras tem sido um modelo útil para investigar a relação entre os esteróides sexuais e o sistema nervoso. Além do sistema neural do canto, o núcleo auditivo nidopálio caudomedial (NCM) tem mostrado ser um sitio de produção e ação de estrógenos e sua fisiologia é influenciada pelo 17_-estradiol (E2) localmente produzido. Neste trabalho nós investigamos os efeitos da aplicação de E2 nos neurônios do NCM caudal de zebra finches (Taeniopygia guttata) usando registros eletrofisiológicos em fatias cerebrais. Em nossos experimentos, nós observamos como o demonstrado previamente por Tremere et al. (2009), que a rápida aplicação de E2 em fatias cerebrais contendo o NCM e áreas adjacentes rapidamente reduz a frequência das correntes pós-sinápticas espontâneas (sPSCs) GABAérgicas, mas não afetou correntes sinápticas GABAérgicas em miniatura. O E2 reduziu a resistência de entrada (Rin) da membrana dos neurônios do NCM, reduzindo a constante de tempo (tau) e aumentando a velocidade do disparo de potenciais de ação (PAs) após injeções de corrente despolarizantes. Interessantemente, o E2 podia despolarizar ou hiperpolarizar o Em em alguns neurônios do NCM. Nossos resultados sugerem que o E2 atua de maneira rápida (não-genômica) sobre a excitabilidade dos neurônios do NCM, onde provavelmente o E2 esteja modulando canais iônicos e/ou receptores de membrana para exercer seus efeitos.

\title{
MODULAÇÃO NITRÉRGICA DA EXCITABILIDADE DOS NEURÔNIOS MAGNOCELULARES DO NÚCLEO SUPRAÓPTICO
}

\author{
Melina Pires da Silva \\ Orientador: Prof. Dr. Wamberto Antonio Varanda \\ Dissertação de Mestrado apresentada em 19/11/2010
}

O núcleo supraóptico (NSO) é uma estrutura localizada bilateralmente ao quiasma óptico, e constituído por um grupamento de neurônios designados como magnocelulares. Esses neurônios são responsáveis pela síntese e liberação de vasopressina e ocitocina, durante alterações do equilíbrio hidroeletrolítico. Apesar de vários neurotransmissores e neuromoduladores já terem sidos identificados nesse núcleo, o óxido nítrico (NO) tem sido alvo de estudos devido sua capacidade de controlar a atividade desses neurônios. Uma vez que sua produção é estimulada durante aumentos da osmolalidade, tem se sugerido que o NO atue como modulador dos processos que levam a sua normalização. Frente a isso, o objetivo deste trabalho foi avaliar a modulação nitrérgica da excitabilidade dos neurônios do núcleo supraóptico em resposta a estímulo hiperosmótico. Empregando a técnica de patch-clamp em fatias coronais do núcleo supraóptico de ratos Wistar com 25 a 30 dias de idade, analisamos no modo current-clamp, a atividade espontânea dos neurônios, e em voltage-clamp as correntes ativadas por hiperpolarização, identificadas biofisicamente e farmacologicamente como Ih (corrente ativada por hiperpolarização). Observamos que a L-Arginina, substrato necessário para formação do NO, causou redução na atividade intrínseca dos neurônios magnocelulares mesmo durante o estimulo hiperosmótico, enquanto que o L-NAME (bloqueador da óxido nítrico sintase) ocasionou um aumento da sua atividade. Estas alterações foram acompanhadas de aumento no pico da hiperpolarização póspotencial (HPP) e da despolarização pós-potencial lenta (DPP). Por outro lado, os neurônios superfundidos com solução hiperosmótica contendo L-NAME, apresentaram respostas opostas. Além disso, a L-Arginina despolarizou os neurônios, enquanto que o tratamento com L-NAME causou hiperpolarização. Não houve mudanças significativas na amplitude dos potenciais de ação. Visto que, as alterações do pico da HPP e da DPP ocorreram no mesmo sentido, e sabendo que a hiperpolarização ativa uma corrente de entrada despolarizante lenta, identificada como Ih, nosso próximo objetivo foi avaliar se esta modulação nitrérgica se faz via alterações nas propriedades desta corrente. Nossos resultados demonstraram que NO causou uma redução significativa nos valores estacionários da corrente Ih enquanto que o L-NAME promoveu um aumento significativo no valor da mesma.

Para verificar a especificidade deste efeito, os experimentos foram repetidos sob as mesmas condições, porém utilizando-se os isômeros inativos D-arginina e D-NAME. No entanto, não houve diferenças significativas entre os grupos. Nossos resultados mostraram, ainda, que a hipertonicidade "per se", promoveu um aumento significativo na corrente Ih. Em resumo, demonstramos que o óxido nítrico possui um papel neuromodulador sobre a excitabilidade dos neurônios magnocelulares do núcleo supraóptico, durante alterações da homeostasia. Tal efeito se faz por alteração do potencial de repouso, bem como dos parâmetros cinéticos do potencial de ação. A nível molecular, estes efeitos macroscópicos podem ser atribuídos a uma ação sobre canais para cátions ativados por hiperpolarização e nucleotídeos cíclicos. 


\title{
Genética
}

\section{AGRUPAMENTO IN SILICO DE GENES POR F ATORES DE TRANSCRIÇÃO E EXPRESSÃO DIFERENCIAL}

\author{
Luciano Angelo de Souza Bernardes \\ Orientadora: Profa.Dra. Silvana Giuliatti \\ Tese de Doutorado apresentada em 14/10/2010
}

Os organismos vivos apresentam milhares de genes, os quais, geralmente de forma conjunta, são continuamente modulados. Entretanto, em resposta as alterações do ambiente, utilizando sua capacidade bioquímica, podem se reprogramarem em função da disponibilidade de nutrientes e as condições físicas e químicas do meio. Assim, se torna uma questão de suma importância compreender os mecanismos que controlam e os elementos característicos envolvidos na modulação dos genes das diferentes fases do desenvolvimento. Pouco ainda é conhecido sobre o complexo que envolve a regulação gênica, mas os fatores de transcrição são um desses elementos. A hipótese levantada é que se os fatores de transcrição são um dos responsáveis pelo perfil de modulação gênica ao longo do tempo, os genes deveriam ser agrupados pelos fatores induzidos que compartilham a cada tempo amostral observado, permitindo um acompanhamento mais dinâmico e não somente pelo perfil de expressão. Desenvolver métodos computacionais eficientes para analisar grande quantidade de dados obtidos em experimentos é um problema desafiante para a computação/bioinformática. Os métodos de agrupamento, atualmente, consideram todos os pontos do perfil de modulação dos genes e quanto maior for a quantidade destes pontos melhor para o agrupamento. O objetivo do projeto proposto foi agrupar genes utilizando fatores de transcrição e perfis de modulação. Para permitir o agrupamento desta forma foi criada uma matriz de presença/ausência de fatores de transcrição para genes, e perfis de modulação foram temporalmente acumulados. Os resultados obtidos mostraram-se melhores que aqueles do método de agrupamento por expressão, estes foram observados pelas interações dos fatores com os genes em subgrupos analisados, chegando em sua maioria a abranger todos eles. A correlação dos subgrupos dos dois métodos mostrou-se parcial, isto é, alguns genes em alguns subgrupos compartilham mesmos TFs e tem perfil de expressão bastante similar.

\section{Ginecologia e Obstetrícia}

\section{VALORES DE REFERÊNCIA DOS PARÂMETROS DOPPLERVELOCIMÉTRICOS DAS ARTÉRIAS PULMONARES E SEUS RAMOS}

\author{
Helmer Herren \\ Orientador: Prof. Dr. Geraldo Duarte \\ Dissertação de Mestrado apresentada em 19/10/2010
}

Introdução: A circulação pulmonar fetal caracteriza-se por ser um território de difícil avaliação de seus parâmetros hemodinâmicos, desafiando os pesquisadores desta área para o desenvolvimento de métodos com aplicabilidade clínica. $\mathrm{Na}$ literatura observa-se poucos trabalhos sobre este tema, apesar da existência de várias situações na prática clínica do obstetra e do neonatologista nas quais o conhecimento de valores de referência da hemodinâmica pulmonar fetal seriam extremamente úteis. Justifica-se, portanto, o interesse e a necessidade de estudos que promovam maior compreensão das particularidades dopplervelocimétricas da circulação pulmonar fetal e de seus ramos. Objetivo: Este estudo foi desenhado para desenvolver curvas de valores de referência dos parâmetros dopplervelocimétricos das artérias pulmonares fetais e de seus ramos. Métodos: Estudo transversal que arrolou 186 gestantes saudáveis, com gestação única e sem doenças fetais. Em 149 delas foi possível completar o estudo utilizando o método Doppler pulsado da artéria pulmonar fetal em seus segmentos proximal, medial e distal. As OVF foram avaliadas por meio do índice de pulsatilidade (IP), índice de resistência (IR), relação sístole/diástole (S/D), do pico de velocidade sistólica (PVS) e da velocidade diastólica final (VDF). Resultados: Verificou-se que as OVF têm características específicas em cada segmento das artérias pulmonares avaliadas. Nos 
segmentos proximal e medial os sonogramas obtidos foram similares, apresentando formato de agulha e rápido aumento das velocidades na fase ascendente da sístole e uma fase descendente mais lenta, em alguns casos terminando com pequeno refluxo protodiastólico seguindo-se por fluxo positivo anterógrado de baixa velocidade na diástole. No segmento distal, o sonograma mostra achatamento das velocidades, porém há fluxo anterógrado positivo em todo o ciclo cardíaco. Todas as variáveis estudadas IP, IR, S/D, PVS e VDF mostraram diferenças significativas quando se comparou os segmentos proximal, medial e distal. No entanto, estes parâmetros dopplervelocimétricos não se alteraram significativamente com o transcorrer da gestação considerando os segmentos pulmonares medial e distal. Encontrou-se diferença apenas nos valores do IP do segmento proximal, com redução significativa dos mesmos entre 20 - 24 semanas e no final da gestação. Conclusão: Os achados deste estudo possibilitaram a criação de curvas de valores de referência que refletem relativa estabilidade hemodinâmica na circulação pulmonar do feto ao longo da gestação. No entanto, estes resultados podem indicar que estes índices não apresentaram sensibilidade suficiente para refletir mudanças sutis da hemodinâmica na circulação pulmonar em um sistema de alta impedância e de fluxo restrito na vida intra-uterina, demandando a busca de novos parâmetros e estratégias que possam responder estes questionamentos.

\title{
QUALIDADE DE VIDA EM MULHERES OBESAS E COM SÍNDROME DOS OVÁRIOS POLICÍSTICOS
}

\author{
Tânia Maria Borges Vieira
}

Orientador: Prof. Dr. Marcos Felipe Silva de Sá

Dissertação de Mestrado apresentada em 25/10/2010

A síndrome dos ovários policísticos (SOP) é uma das desordens endócrinas mais comuns na idade reprodutiva, sendo a sua prevalência de 6 a $10 \%$ na população feminina. A SOP associada à obesidade pode agravar a saúde física e mental com um impacto negativo no funcionamento bio-psico-social. Os distúrbios metabólicos e as manifestações clínicas do hiperandrogenismo, comuns em mulheres com SOP tem levado ao aumento dos distúrbios psicológicos e redução na qualidade de vida $(\mathrm{QV})$. Alguns estudos têm mostrado uma piora da QV na SOP, mas não fazem distinção sobre os efeitos que a própria obesidade pode acarretar a QV, uma vez que mais de 50\% das pacientes SOP apresentam sobrepeso e obesidade. O presente estudo objetivou avaliar se há diferença na QV de pacientes com SOP obesas comparadas a controles obesas com ciclos ovulatórios. Foram incluídas 35 obesas com SOP e 28 obesas com ciclos ovulatórios, com idade entre 20 e 40 anos, IMC ${ }^{3} 30$ e que aceitaram assinar o TCLE. Utilizou-se para a caracterização da população o questionário sócio-demográfico, médico, reprodutivo e somatométrico e para a avaliação da qualidade de vida, o questionário SF-36, que avalia os componentes da saúde física e os componentes da saúde mental. As pacientes com SOP mostraram melhor escore no que diz respeito ao domínio da capacidade funcional $(73,43 \pm 20,57$ vs $59,46 \pm 22,08)(\mathrm{p}=0,01)$. Para os demais domínios não houve diferenças significativas entre os grupos. Nossos resultados sugerem que o aumento de androgênios comum em obesas com SOP possa estar associado à melhor capacidade funcional.

\section{EFEITOS DO CÂNCER DE MAMA E SEU TRATAMENTO SOBRE O PERIODONTO DE MULHERES NA PÓS-MENOPAUSA}

\author{
Juliana Amódio \\ Orientador: Prof. Dr. Francisco José Candido dos Reis \\ Dissertação de Mestrado apresentada em 03/12/2010
}

Diversas estratégias, como o uso de terapias combinadas no tratamento do câncer de mama, têm contribuído para o aumento da sobrevida das mulheres com esta doença. As diversas modalidades de tratamento apresentam, no entanto, diversos efeitos sobre outros sistemas orgânicos. Estes efeitos, somados à influência da menopausa no periodonto podem gerar um desequilíbrio na homeostasia do mesmo, acarretando prejuízo na qualidade de vida bucal e sistêmica da paciente. No presente estudo avaliamos o efeito do câncer de mama e de seu tratamento sobre a saúde oral de 48 mulheres pareadas por idade. O tratamento oncológico, associado às mudanças orais durante a menopausa e a condição de base das pacientes, podem ser responsáveis pelo agravamento da condição periodontal das mesmas. O acompanhamento odontológico antes, durante e após o tratamento do câncer pode afetar positivamente a qualidade de vidas das pacientes. 


\title{
REPRODUTIBILIDADE INTRAOBSERVADOR E INTEROBSERVADOR DA DILATAÇÃO MEDIADA POR FLU- XO E VARIAÇÃO DO ÍNDICE DE PULSATILIDADE DA ARTÉRIA BRAQUIAL EM MULHERES GESTANTES
}

\author{
Jailson Costa Lima
}

Orientador: Prof. Dr. Francisco Mauad Filho

Dissertação de Mestrado apresentada em 08/12/2010

Introdução e Objetivo: Entre as técnicas usadas para a avaliação da função endotelial, destaca-se a medida a dilatação mediada por fluxo (DMF). Contudo, esse método é associado com muitas dificuldades técnicas. A análise da variação do índice de pulsatilidade ( $\Delta \mathrm{IP})$ mostra-se mais simples para avaliar a resposta endotelial, pois a vasodilatação leva à decréscimo na resistência vascular. Objetivamos avaliar a reprodutibilidade intra e inter observador da DMF da artéria braquial e da $\Delta \mathrm{IP} 1$ minuto depois de 5 minutos de compressão do antebraço em mulheres grávidas. Métodos Dilatação mediada por fluxo e $\Delta$ IP foram avaliados em 31 mulheres grávidas. Foram realizadas três avaliações em dias consecutivos e distintos, sendo os dois primeiros dias por um mesmo observador e, o terceiro dia por um segundo observador. Coeficiente de correlação intra-classe e limite de concordância 95\% (LoA 95\%) foram utilizados para avaliar concordância intra e inter observador. Resultados: Uma ampla variação foi observada na resposta ao estímulo para a $\Delta$ IP (-58.99\% a $86.71 \%)$, maior do que a DMF $(2.38 \%$ a $27.01 \%)$. Os valores de ICC foram mais altos para $\triangle \mathrm{IP}$ (ICC intraobservador $=0,90$; interobservador $=0,94)$ que para DMF $($ ICC intraobservador $=0,69$; inter observador $=0,61)$. Considerando a variação da resposta ao estímulo, o LoA 95\% obtido para DMF (aproximadamente $\pm 9 \%$ ) foi mais preocupante do que o observado para a $\Delta \mathrm{IP}$ (aproximadamente $\pm 17.0 \%$ ). Conclusão: A $\Delta \mathrm{IP}$ da artéria braquial após a compressão por 5 minutos do antebraço em mulheres grávidas mostrou-se um método significativamente mais reprodutível que a DMF. Além disso, a $\Delta \mathrm{IP}$ é considerado um método de menor grau de dificuldade e requer menos recurso para sua execução. Contudo, estudos abrangendo sujeitos com fatores de risco cardiovascular correlacionando a DMF e a $\triangle \mathrm{IP}$ tornam-se necessários para validar esse método no estudo da disfunção endotelial.

\section{Imunologia Básica e Aplicada}

\section{PROTEÍNAS DE MICRONEMA DE Toxoplasma gondii: AVALIAÇÃO ESTRUTURAL E DAS ATIVIDADES BIOLÓGICA E VACINAL}

\author{
Camila Figueiredo Pinzan \\ Orientadora: Profa. Dra. Maria Cristina Roque Antunes Barreira \\ Tese de Doutorado apresentada em 18/10/2010
}

As proteínas de micromema TgMIC1, TgMIC4 e TgMIC6 (MICs) de Toxoplasma gondii formam um complexo na superfície do parasita responsável pela adesão e invasão a muitos tipos celulares. Sabe-se que a liberação desse complexo é pré-requisito para o estabelecimento e manutenção da infecção. Este estudo teve como objetivo (1) produzir as proteínas recombinantes TgMIC1 e TgMIC4 de T. gondii; (2) estudar essas proteínas recombinantes, bem como proteínas ligantes de lactose (complexo $\mathrm{Lac}^{+}$) isoladas do parasita, quanto a aspectos estruturais e de especificidade de ligação a glicanas; (3) avaliar atividades biológicas desempenhadas pelas proteínas recombinantes e pela fração Lac+ de T. gondii; (4) investigar a propriedade vacinal das proteínas recombinantes e da fração Lac+ de T. gondii. O insucesso das abordagens para produzir as proteínas recombinantes na forma solúvel motivou a sua purificação a partir de corpos de inclusão. Após a realização de procedimentos de refolding, as preparações obtidas mostraram-se solúveis, homogêneas e contendo as proteínas corretamente dobradas. A estrutura do complexo Lac+, constituído pelas proteínas TgMIC1/4 nativas, foi avaliada por microscopia eletrônica, que revelou ser o complexo correspondente a partículas circulares de excelente simetria, adequadas para estudos futuros de reconstituição em três dimensões do complexo TgMIC1/4. A eletroforese em condições não desnaturantes mostrou que o complexo Lac+ tem massa molecular aparente de 669kDa que, em condições desnaturantes (mas não redutoras) origina componentes protéicos de 420 e 240kDa. Postulamos que o componente de 420kDa corresponda a hexâmeros de TgMIC4, enquanto o de 240kDa corresponda a tetrâmeros de TgMIC1. A associação entre esses dois tipos de oligômeros seria estabelecida por ligações não covalentes. Já a oligomerização de moléculas de TgMIC4 (70kDa) e de TgMIC1 (60kDa), respectivamente, ocorreria por interações covalentes. A existência na fração Lac+ de TgMIC6 foi investigada, uma vez que há relatos de que essa proteína seja responsável pelo ancoramento de TgMIC1/ 
4 na membrana do parasita. Através de imunoblot descartou-se a inclusão de TgMIC6 nos complexos Lac+, purificado do parasita. A análise por glycoarray, mostrou que rTgMIC1 liga-se a glicanas terminadas em sialil-lactosamina e rTgMIC4 liga-se a glicanas terminadas em lactosamina. A análise das proteínas nativas, contidas na fração Lac+, mostrou ligação a ambos os tipos de glicanas, como esperado. Ensaios de atividade biológica demonstraram que os três principais tipos de células fagocíticas (neutrófilos, macrófagos e células dendriticas) produzem IL-12 em resposta ao estímulo com as preparações de MICs. Além disso, células dendríticas pulsadas com essas preparações induziram a produção de IFN- $\gamma$ por células T CD4. Células HEK 293 tranfectadas com plasmídeo de TLR2 em associação com plasmídeo contendo NFkB combinado com gene repórter de luciferase frente ao estímulo com rTgMIC1, rTgMIC4 ou Lac+ tiveram NF8`B translocado, sugerindo que essas lectinas interajam com glicanas associadas ao ectodomínio de TRL2. Realizamos experimentos com o intuito de averiguar se o processo de imunização com as diferentes proteínas de micronemas ou combinações das mesmas, geraria proteção de camundongos contra a toxoplasmose. A imunização induziu um padrão de resposta humoral misto, verificado pelos níveis séricos similares de IgG1 e IgG2b reativos com antígeno solúvel de T. gondii. Induziu ainda além disso, resposta celular de padrão Th1 (protetor na toxoplasmose), manifesto pela deteç̧ão das citocinas IFN- $\gamma$ e IL-12, mas não de IL-4, nos sobrenadantes de cultura das células esplênicas dos animais imunizados. Animais imunizados e desafiados oralmente com cistos da cepa ME49 de T. gondii apresentaram uma redução significativa na mortalidade e no número de cistos cerebrais, em comparação aos animais controles. A ocorrência de redução de $68 \%$ na detecção de cistos cerebrais e o aumento de $80 \%$ da sobrevida dos camundongos imunizados com a preparação constituída de rTgMIC1-4-6, mostra que essa preparação vacinal foi a melhor indutora de proteção, podendo corresponder a uma forte candidata a constituir preparação vacinal que evite ou amenize os efeitos deletérios da infecção por T. gondii.

\title{
TRIAGEM E SELEÇÃO DE ANTÍGENOS SALIVARES DO CARRAPATO Rhipicephalus (B.) microplus POR MEIO DE ESTRATÉGIAS GENÔMICA E PROTEÔMICA PARA O DESENVOLVIMENTO DE UMA VACINA ANTICARRAPATOS
}

\author{
Daniela Dantas Moré
}

Orientadora: Profa. Dra. Beatriz Rossetti Ferreira

Tese de Doutorado apresentada em 29/10/2010

Carrapatos são ectoparasitas hematófagos que coevoluiram simbioticamente com hospedeiros terrestres e adquiriam diversos mecanismos de evasão das respostas montadas por seus hospedeiros durante os longos períodos de infestação. Essa modulação se faz essencialmente através da inoculação de saliva no sítio de alimentação que contém uma série de moléculas com funções biológicas relevantes. Em contrapartida, a resposta imune dos hospedeiros também é capaz de interferir com a expressão gênica em seus eventuais parasitas. Bovinos desenvolvem uma resposta imunológica contra moléculas inoculadas durante a infestação por carrapatos, embora algumas raças apresentem diferentes padrões genéticos de suscetibilidade a novas infestações. A indução natural de resposta imune protetora contra infestações subsequentes em raças zebuínas sugere a possibilidade do controle através da vacinação dos hospedeiros. A redução no grau das infestações traria uma diminuição significativa dos prejuízos sanitários e financeiros causados por carrapatos. As tecnologias genômicas e proteômicas tem desempenhado um importante papel na busca por antígenos candidatos para o desenvolvimento de várias vacinas, como o fez nesse estudo. Genes de interesse (GIs) clonados foram selecionados através da análise de bibliotecas de cDNA de glândulas salivares de carrapatos, produzidos para inoculação sob a forma de DNA nu na pele de bovinos resistentes às infestações (raça nelore) e avaliação de resposta cutânea tardia. Posteriormente, carrapatos foram inoculados com moléculas fita dupla de RNA (dsRNA) para o silenciamento gênico de alguns dos GIs através de interferência por RNA e tiveram seus parâmetros de desempenho biológicos e reprodutivos avaliados após a alimentação em bovinos. Em seguida, as proteínas recombinantes foram produzidas em sistema de transcrição e tradução in vitro (IVTT). Os resultados mostraram que dos 23 GIs avaliados quanto à indução de resposta cutânea tardia com a inoculação de DNA nu, apenas dois não foram capazes de induzir resposta como eritema ou enduração; com relação às células presentes no sítio de inoculação dos GIs não foram observadas diferenças significativas. Em seguida, 15 GIs foram selecionados para avaliação do efeito de interferência por RNA. O silenciamento gênico de cinco GIs foi capaz de interferir consistentemente com o desempenho dos carrapatos alimentados em hospedeiros suscetíveis, prejudicando principalmente o peso das fêmeas alimentadas e da massa de ovos, a eficiência reprodutiva e a taxa de eclosão. O silenciamento do GI SIGP G05 merece destaque, pois levou a um maior comprometimento no desempenho dos carrapatos, provocando a redução de 47, 67, 53 e 76\% nos parâmetros citados. Em seguida, com exceção do GI CEM G04, todas as proteínas recombinantes foram sintetizadas com sucesso, com obtenção de aproximadamente $20 \mu \mathrm{g}$ de cada proteína (55,8 a 111,6 
$\mathrm{ng} / \mu \mathrm{L})$ que poderão ser agora testadas como imunógenos para auxiliar o desenvolvimento de uma vacina anticarrapato.

\title{
LUPUS ERITEMATOSO SISTÊMICO: POLIMORFISMOS GÊNICOS E EXPRESSÃO DE MOLÉCULAS DE ADESÃO E IMUNO-REGULATÓRIAS
}

\author{
João Alexandre Trés Pancoto
}

Orientador: Prof. Dr. Eduardo Antonio Donadi

Tese de Doutorado apresentada em 24/11/2010

O Lúpus Eritematoso Sistêmico (LES) é doença autoimune multissistêmica, caracterizada, clinicamente, por períodos de remissões e recidivas e, laboratorialmente, pela presença de anticorpos contra diversos antígenos nucleares e celulares. Um dos achados laboratoriais de importância é a neutropenia. A redução do número de neutrófilos pode ser responsável pelo aumento à susceptibilidade a infecções, constituindo assim causa importante de morbidade e mortalidade nesses pacientes. Considerando que o LES seja doença de herança complexa e que diversas alterações das células do sistema imune estejam presentes, avaliamos os polimorfismos de diversos genes relacionados com a patogenia da doença, incluindo genes situados dentro do MHC, incluindo a região promotora do TNF (-308A/G e -238A/G) e região 3' não traduzida do HLA-G (presença ou ausência 14 pares de base e $+3142 \mathrm{C} / \mathrm{G})$, e ainda, de outras citocinas como IFN-g (+874A/ T no intron 1) e IL-18 (-607A/C e -137C/G na região promotora), codificadas por genes fora do MHC, utilizando DNA amplificado e hibridado com iniciadores específicos. Além disso, avaliamos, por citometria de fluxo, apoptose/necrose (Anexina V e Iodeto de propídio) de neutrófilos e a expressão de moléculas de adesão celular (CD11b/mac-1 e CD62L) e HLA-G em celulas circulantes de pacientes com LES, apresentando neutropenia. Finalmente, quantificamos os níveis solúveis de moléculas imunoreguladoras HLA-G (ELISA e Luminex) e galectina 1 (ELISA). Dentre os sítios polimórficos estudados, apenas o alelo TNF -308A e o genótipo -308A/G foram associados com susceptibilidade ao desenvolvimento de LES. Comparados com os controles, pacientes com LES apresentaram aumento de necrose de neutrófilos, enquanto, apoptose e a expressão de moléculas adesão (CD62L e CD11b/mac-1) em neutrófilos não apresentaram diferenças significantes, havendo apenas tendência de dessas moléculas em pacientes. Ainda, observamos correlação positiva entre expressão de HLA-G e as moléculas de adesão CD62L e CD11b/mac-1. Linfócitos de pacientes apresentaram aumento da expressão de HLA-G de superfície, ao passo que, em neutrófilos de pacientes e de controles, a expressão gênica e antigênica de HLA-G foi baixa. Os níveis solúveis de HLA-G em pacientes foram significantemente mais baixos em relação aos controles, enquanto, os níveis de galectina-1, que apresenta propriedades imunomoduladoras semelhantes ao HLAG, não foram diferentes dos controles. Em conjunto, esses dados indicam que pacientes com LES apresentam desregulação da morte celular e alterações de expressão de moléculas de adesão e imunoregulatórias nas superfícies de células circulantes.

\section{DETECÇÃO DE HANTAVÍRUS EM ROEDORES SILVESTRES E ESTUDO DE SUA DINÂMICA POPULACIONAL NA REGIÃO NORDESTE DO ESTADO DE SÃO PAULO}

\author{
Gilberto Sabino-Santos Jr \\ Orientador: Prof. Dr. Luiz Tadeu Moraes Figueiredo \\ Dissertação de Mestrado apresentada em 14/12/2010
}

Hantavirus são vírus zoonóticos principalmente de roedores silvestres, pertencentes à família Bunyaviridae. Entre os reservatórios naturais, os hantavírus não causam nenhum efeito patogênico aparente, contudo, quando transmitidos ao homem, estes vírus podem causar graves doenças como a febre hemorrágica com síndrome renal (FHSR) na Eurásia e uma síndrome pulmonar e cardiovascular (SPCVH) no continente Americano. Na América do Sul, os Hantavírus estão associados a roedores-reservatório da subfamília Sigmodontinae (família Cricetidae). Neste estudo, objetivou-se detectar a infecção por Hantavírus em pequenos mamíferos silvestres vivendo em quatro ambientes distintos e avaliar a dinâmica populacional de possíveis animais-reservatório considerando a influência de parâmetros ecológicos com a infecção por Hantavírus na região Nordeste do Estado de São Paulo, Brasil. Para tanto, de junho de 2008 a julho de 2009, capturaramse pequenos mamíferos silvestres vivendo em 4 ambientes: áreas com vegetações nativas de cerrado e floresta semidecidual atlântica e vegetações modificada por culturas de cana de açúcar (Saccharum officinarum) e capim braquiária (Brachiaria decumbens), nos Municípios de Batatais, Cajuru e Luis Antônio. Pequenos mamíferos foram capturados vivos em duas grades de 100 armadilhas Sherman's, colocadas em intervalos de 10-m, por 2-3 noites consecutivas. As grades foram 
separadas por pelo menos 800-m para representação individual da população. Também, foi feita uma linha para sacrifício com 100 armadilhas Sherman's dispostas 5-10-m, uma da outra, para coleta de órgãos dos animais capturados. Os animais capturados foram identificados pelos caracteres morfológicos, marcados para recaptura, quando das grades, e tiveram sangue total coletado pelo seio retro-orbital. Anticorpos IgG para Hantavírus foram detectados por ELISA indireto utilizando a proteína $\mathrm{N}$ recombinante do Hantavírus Araraquara. Amostras de tecido de três roedores infectados foram utilizadas para o isolamento viral. Durante esse período 568 animais foram capturados, com um sucesso de captura de 4,8 $\%$. Os roedores silvestres mais encontrados foram: Necromys lasiurus (212), Akodon sp (151) e Calomys tener (103). Houve uma diferença significativa entre os ambientes estudados quanto à abundância de animais, mas não em termos de biodiversidade das espécies. A soropositividade para Hantavírus nos roedores silvestres foi de $6.3 \%$ e encontrou-se, apenas, o vírus Araraquara infectando os animais. Observou-se maior abundância de roedores silvestres e também, mais alta soropositividade no ambiente de campim braquiária, mostrando-se este um fator de risco para infecção por Hantavírus nestes animais e no homem. A abundância de roedores e a infecção por Hantavírus nos animais mostraram tendência sazonal, com elevação na estação seca, de abril a setembro. Também, a taxa de infecção por Hantavírus mostrou-se maior em animais adultos e subadultos que em juvenis. Ainda, identificou-se um provável spillover do Hantavírus Araraquara, a partir de seu reservatório $N$. lasiurus para C. tener e possivelmente, A. montensis e Rhipidomys sp. Desta forma, sugerimos que a degradação do ambiente e a perda da diversidade biológica são fatores de risco à infecção por Hantavírus nos roedores Sigmodontinae podendo ocasionar fenômenos de spillover na região estudada.

\title{
Neurologia
}

\section{EFEITO DA NEUROTRANSMISSÃO NORADRENÉRGICA NO Locus Coeruleus NA ANTINOCICEPÇÃO Pós-ictal}

\author{
Tatiana Tocchini Fellippotti \\ Orientador: Prof. Dr. Norberto Cysne Coimbra \\ Tese de Doutorado apresentada em 19/10/2010
}

Sabe-se que o período pós-ictal é seguido por antinocicepção. Muitos neurotransmissores e seus receptores estão envolvidos nas diversas formas de analgesia, como, por exemplo, peptídeos opioides endógenos, acetilcolina e monoaminas. A analgesia pós-ictal é uma das muitas formas de modelo experimental de antinocicepção em que o recrutamento de cada um desses neurotransmissores já foi descrito. Para o efeito do controle descendente da dor, é considerada a participação de estruturas supraespinais, como o núcleo dorsal da rafe (NDR), a substância cinzenta periaquedutal (SCP) e o Locus Coeruleus (LC). Sendo o LC o núcleo noradrenérgico mais importante do tronco encefálico, o objetivo desse trabalho foi estudar o envolvimento do sistema noradrenérgico no LC na organização da analgesia pós-ictal. Ioimbina, propranolol e norepinefrina foram unilateralmente microinjetados no LC de ratos (Wistar). Em seguida, por via intraperitoneal, foi administrado pentilenotetrazol (PTZ; 64mg/kg), um antagonista farmacológico não-competitivo que bloqueia o influxo de cloro mediado pelo GABA. A analgesia que segue as crises convulsivas foi antagonizada pela iombina, propranolol, e também pela microinjeção de norepinefrina no LC. As crises convulsivas, estudadas no presente trabalho, sofreram influência da administração dos fármacos intra-LC, levando a um aumento na duração das convulsões. Desta forma, podemos sugerir o envolvimento do sistema noradrenérgico do LC na modulação da analgesia pós-ictal e dos processos convulsivos tônicoclônicos.

\section{ESTUDO DA DISTRIBUIÇÃO DA PERDA SENSITIVA NA HANSENÍASE}

\section{Christiane Borges Abrão dos Santos}

Orientador: Prof. Dr. Wilson Marques Junior

Dissertação de Mestrado apresentada em 19/10/2010

Contextualização: Na caracterização da neuropatia da moléstia de Hansen, dois detalhes precisam ser melhor definidos, a distribuição da perda sensitiva e a ordem em que as diferentes fibras são afetadas. Objetivo: O objetivo deste trabalho é caracterizar a distribuição da perda sensitiva ao tato e à dor na hanseníase e determinar qual das duas formas de 
sensibilidade é mais precocemente afetada. Metodologia: Foram avaliados trinta portadores de hanseníase, divididos em 5 grupos de acordo com a forma clínica da doença e vinte indivíduos controles, não portadores de neuropatia periférica. As sensibilidades tátil (monofilamentos de Semmes-Weinstein) e dolorosa (alfinete) foram mensuradas nos MMSS e MMII, incluindo mãos e pés, na face e nas orelhas. Os segmentos corporais foram subdivididos em 212 subáreas com aproximadamente $3 \mathrm{~cm} 2$ cada. Os dados foram comparados utilizando-se análise multivariada não paramétrica de Kruskall Wallis e através de análise descritiva. Resultados: Observou-se que a perda sensitiva predominou na região posterior do cotovelo ( $\mathrm{p}>0,001$ ); na região posterior do antebraço até dorso das mãos, na palma das mãos, nos joelhos e na faixa lateral da perna até a região distal nos pés. A região posterior do cotovelo, em particular, tem excelente valor diagnóstico para detecção da neuropatia da hanseníase. A sensibilidade dolorosa foi envolvida mais precocemente e mais extensivamente que a tátil, contribuindo para a caracterização e identificação desta neuropatia. Conclusões: A perda sensitiva na hanseníase tem um padrão de distribuição topográfica preferencial, comprometendo mais precoce e intensamente a dor em relação ao tato, observações que contribuem para a caracterização e diagnóstico da neuropatia hansênica.

\title{
AVALIAÇÃO DO EIXO HIPOTÁLAMO-HIPÓFISE-ADRENAL EM RATOS WISTAR AUDIOGÊNICOS (WAR)
}

\author{
Eduardo Henrique de Lima Umeoka \\ Orientador: Prof. Dr. Norberto Garcia Cairasco \\ Dissertação de Mestrado apresentada em 30/11/2010
}

Modelos experimentais de crises audiogênicas (CAs) no rato são reconhecidos como um modelo de crises generalizadas tônico-clônicas e têm sido introduzidas em diferentes laboratórios para estudo das epilepsias. A cepa Wistar Audiogênic Rats (WAR) é uma linhagem de ratos Wistar geneticamente sensíveis à crises audiogênicas (CAs). Durante a crise existe ativação do eixo Hipotálamo-Hipófise-Adrenal (HHA), que faz parte de um sistema neuroendócrino que de acordo com estímulos internos ou externos, apresenta variações a fim de manter a homeostase do organismo. O objetivo desse trabalho foi avaliar o eixo HHA de ratos da cepa WAR e verificar de que maneira as alterações desse eixo podem alterar as crises audiogênicas. Para isso verificamos a resposta da hipófise e da glândula adrenal a diferentes condições como estresse de restrição e variação circadiana, verificamos ainda a resposta da glândula adrenal ao estímulo com hormônio adrenocorticotrófico (ACTH) exógeno, o peso dos animais do nascimento aos 63 dias de idade, a histopatologia e a morfometria da glândula adrenal. Para verificar como os hormônios do eixo HHA influenciam as CAs, induzimos as crises após estresse de restrição agudo e crônico e após injeção de espironolactona, antagonista de receptores de mineralocorticóides. Os resultados mostram que os animais da cepa WAR, embora menores que os Wistar, apresentam maior peso da glândula adrenal a qual é hiperplásica nesses animais. Ratos da cepa WAR também apresentam alterações na variação circadiana de ACTH com ausência do pico noturno de secreção, e tiveram um valor de corticosterona plasmática, após injeção de ACTH exógeno, significativamente maior que os Wistar. Quando submetidos ao estresse de restrição, ratos WARs apresentaram um aumento nas concentrações plasmáticas de ACTH quando comparados com os Wistar. Apesar dessas diferenças fisiológicas no eixo HHA os WARs não mostraram alterações na gravidade de crises após estresse de restrição agudo, porém apresentaram diferenças nas gravidades das crises audiogênicas após a realização de um processo de estímulos repetidos (20 estímulos em 10 dias) para o recrutamento de estruturas límbicas (kindling audiogênico), pareado com estresse crônico de restrição.

\section{IMPORTÂNCIA DA PARTICIPAÇÃO MATERNA NO PROCEDIMENTO DE INTERVENÇÃO ESSENCIAL EM CRIANÇAS NASCIDAS PRÉ-TERMO}

\author{
Renata de Freitas Martins \\ Orientadora: Profa. Dra. Carolina Araujo Rodrigues Funayama \\ Dissertação de Mestrado apresentada em 1\%12/2010
}

Os grandes avanços que ocorreram na terapia intensiva neonatal nos últimos anos contribuíram para a diminuição da mortalidade neonatal em recém-nascidos (RNs) pré-termo. Este fato criou a necessidade de melhorar a qualidade de vida desses bebês. Neste sentido, o reconhecimento das crianças de risco para alterações no desenvolvimento é de grande importância para permitir um diagnóstico e uma intervenção essencial. O objetivo do presente estudo foi avaliar a eficiên- 
cia de um programa de intervenção essencial com bebês pré-termo de baixo peso ao nascimento levando em consideração a influência da participação ativa ou não dos pais durante o processo de atendimento, comparando os grupos 1 e 2 em três momentos de avaliação: antes, durante e ao final da intervenção, que ocorreu por um período de 6 meses. Para realização da avaliação do desenvolvimento infantil foi utilizado o teste de triagem Denver II que é delineado para aplicação em crianças desde o nascimento até a idade de 6 anos. Consiste em 125 itens divididos em quatro grupos: Pessoal-social, motor fino adaptativo, motor grosseiro e linguagem; e foi escolhido por ser o mais utilizado pelos profissionais da área da saúde para triagem em populações assintomáticas e por permitir fácil treinamento e administração rápida (20 minutos). Foi utilizada também a Alberta Infant Motor Scale (AIMS), uma escala padronizada que se propõe a avaliar e monitorar o desenvolvimento motor amplo de lactentes de zero a dezoito meses ou até a aquisição da marcha. A avaliação é realizada a partir da observação livre da criança em quatro posturas: supino, prono, sentado e de pé. O teste avalia a permanência na postura, atitude antigravitacional e a capacidade da criança em realizar transições entre as posturas de forma independente. O estudo constituiu-se de uma amostra de 18 bebês pré-termo de ambos os sexos, nascidos com mediana de peso de $1320 \mathrm{~g}$ para o Grupo 1 (G1) e $1250 \mathrm{~g}$ para o Grupo 2 (G2) e faixa etária média de 43,2 dias de idade corrigida, à primeira avaliação. Os participantes foram subdivididos em dois grupos, sendo que os nove bebês do G1 receberam intervenção com a presença e participação dos pais e os nove bebês participantes do G2 receberam o mesmo tipo de tratamento, porém sem a presença dos pais durante as intervenções, os quais receberam todas as informações e orientações ao final de cada atendimento. O programa de intervenção essencial foi baseado nos seguintes aspectos: facilitação de trocas posturais básicas, estimulação do sustento cefálico, estimulação de coordenações sensório-motoras primárias, além de facilitação do vínculo por meio de técnicas de massagem e confecção de brinquedos com sucata, facilitando assim a exploração ativa do ambiente. $\mathrm{Na}$ análise dos resultados do teste de Denver II foi encontrado risco para atraso em 4 bebês dos G1 e 4 do G2 com maiores índices para as áreas motoras finas (MFA) e grosseira (MG). Com base nos resultados da comparação entre os grupos, observou-se que os ganhos nas pontuações da AIMS, entre primeira e terceira avaliações, foram superiores no G1 em relação ao G2 quando analisados ao nível de significância de $5 \%(\mathrm{p}=0,01)$. O presente trabalho sugere que a presença materna durante as sessões de intervenção constitui-se em fator positivo para melhores resultados.

\title{
INIBIDORES DE FOSFATIDILINOSITOL-3-CINASE (PI3K) E NEUROPROTEÇÃO MEDIADA PELA CASCATA DE SINALIZAÇÃO DA AKT NA FASE AGUDA DO MODELO DE PILOCARPINA
}

\author{
Priscila Alves Balista \\ Orientador: Prof. Dr. João Pereira Leite \\ Dissertação de Mestrado apresentada em 16/12/2010
}

Introdução: A epilepsia do lobo temporal (ELT) é a forma mais frequente de epilepsia em adultos. Um modelo experimental de ELT consiste na indução de status epilepticus (SE) em animais por administração de Pilocarpina. Este modelo induz mudanças patofisiológicas e comportamentais em ratos muito semelhantes às observadas em seres humanos com ELT. Apesar da literatura apresentar dados relacionados às respostas celulares, pouco se conhece a respeito do envolvimento de cascatas de sinalização com insultos epileptogênicos no sistema nervoso. A enzima fosfatidilinositol-3cinase (PI3K) está envolvida na ativação da cascata de sinalização intracelular da Akt. A Akt é uma proteína cinase especifíca de serina/treonina cuja forma ativa proporciona um controle no crescimento e proliferação celular, bem como induz um "sinal de sobrevivência" para a proteção de células contra a apoptose. Alguns estudos mostram que a ativação da PI3K é inibida por potentes drogas, tais como a LY294002 e a Wortmanina. A PI3K ativa a Akt e a cascata de sinais extra e intracelulares neuroprotetores pós-insultos. O estudo da ação de inibidores da PI3K em modelos de epilepsia pode fornecer dados sobre o envolvimento da Akt em sinais neuroprotetores. Objetivos: Avaliar o efeito do SE por injeção intrahipocampal de Pilocarpina na ativação da Akt, bem como os efeitos do bloqueio desta cascata sobre as alterações patológicas observadas no hipocampo de ratos na fase aguda pós-SE. Metodologia: Ratos da cepa Wistar machos (250$300 \mathrm{~g}$ ) foram divididos em grupos de tratamento, sendo tratados com injeções ipsilaterais na região posterior do hipocampo, com uma hora de intervalo entre drogas, das drogas: Salina e Pilocarpina (grupo Sal+Pilo), LY294002 e Pilocarpina (LY+Pilo) e Wortmanina e Pilocarpina (Wort+Pilo). No grupo considerado como controle foram injetadas as seguintes drogas: Salina e Salina (grupo Sal+Sal) ou Dimetilsulfóxido e Salina (grupo DMSO+Sal). O tempo de SE induzido por Pilocarpina foi fixado em 2 horas. Grupos de animais foram sacrificados nos instantes de 1 dia e 7 dias após o SE e seus encéfalos foram processados objetivando a imuno-histoquímica para NeuN, GFAP e Akt (pan). Resultados: A densidade neuronial na região do hilo do hipocampo foi menor no grupo Sal+Pilo, seguido dos grupos LY+Pilo e Wort+Pilo, avaliando-se os vários níveis de formação hipocampal e região posterior. Para a análise da astrogliose, na camada granular, o 
grupo LY+Pilo apresentou maior número de astrócitos positivos; na região do hilo hipocampal, os grupos LY+Pilo e Wort+Pilo apresentaram baixa expressão para a proteína Akt, comparados aos grupos Controles; assim como o grupo Wort+Pilo, em CA2, apresentou baixa expressão da proteína Akt somente na região posterior. Os animais Sal+Pilo sobrevida-7dias pós-SE revelaram maior expressão da Akt quando comparados com o grupo Sal+Pilo sobrevida-1dia pós-SE. Quanto à análise comportamental, o grupo Wort+Pilo apresentou maior latência para o início do $S E$ que o grupo Sal+Pilo, não sendo observado diferença de severidade, uma vez atingido o SE. Conclusões: Na hipótese de trabalho, o uso de inibidores da fosforilação de Akt resultaria em maior morte neuronial, astrogliose e expressão inalterada da Akt. Ao contrário do esperado, os grupos que receberam injeções intra-hipocampais de inibidores de Akt, antes da indução de $S E$, exibiram menor perda neuronial, menor astrogliose e menor expressão da Akt para os vários níveis de formação hipocampal e no hipocampo posterior. Porém, o grupo Sal+Pilo sobrevida-7 dias pós-SE exibiu maior expressão para Akt quando comparado com o grupo Sal+Pilo de sobrevida-1 dia pós-SE. Além disso, o pré-tratamento com Wortmanina demonstrou um maior tempo de latência para o início do SE, o que nos sugere uma maior neuroproteção do que LY294002.

\title{
Oftalmologia, Otorrinolaringologia e Cirurgia de Cabeça e Pescoço
}

\section{ESTUDO MORFOMÉTRICO POR RESSONÂNCIA MAGNÉTICA E CEFALOMETRIA DA FARINGE EM PACIENTES COM SÍNDROME DA APNEIA/HIPOPNEIA OBSTRUTIVA DO SONO (SAHOS) SUBMETIDOS À CIRURGIA DE AVANÇO MAXILO-MANDIBULAR}

\author{
Ana Célia Faria \\ Orientador: Prof. Dr. Francisco Veríssimo de Mello-Filho \\ Tese de Doutorado apresentada em 13/10/2010
}

Introdução: O estudo da Síndrome da Apneia/Hipopneia Obstrutiva do Sono (SAHOS) tem merecido atenção crescente nos últimos anos, uma vez que vários aspectos importantes sobre sua fisiopatologia e abordagem terapêutica não foram ainda suficientemente esclarecidos. Uma adequada compreensão das estruturas que compõem a faringe e sua função nos pacientes com SAHOS é necessária para elucidar a patogênese dessa desordem, assim como para permitir seleção da terapêutica mais indicada para o tratamento do paciente. A cirurgia de avanço maxilo-mandibular (CAMM) tem sido descrita como o tratamento cirúrgico mais efetivo para SAHOS, com índices de sucesso acima de $90 \%$. A maioria dos trabalhos sobre a CAMM objetiva comprovar a eficácia desta modalidade de tratamento, porém poucos descrevem as alterações anatômicas produzidas pela cirurgia na faringe, sendo que o exato mecanismo pelo qual a CAMM aumenta a faringe ainda não é conhecido. Objetivo: Localizar e quantificar as mudanças anatômicas da faringe, ocorridas em pacientes com SAHOS após a realização de CAMM, utilizando dois métodos: cefalometria e ressonância magnética. Material e Métodos: Participaram 20 pacientes (15 do sexo masculino e 5 do sexo feminino) com diagnóstico polissonográfico de SAHOS. Todos os pacientes realizaram telerradiografia em perfil para análise cefalométrica, e aquisição de Imagens por Ressonância Magnética (RM) realizada em vigília e durante o sono induzido por Propofol. Os exames de polissonografia, cefalometria e RM foram realizados no pré-operatório e repetidos seis meses após os pacientes serem submetidos à CAMM. A cefalometria foi padronizada para obtenção de medidas descritivas das dimensões das vias aéreas, posição do osso hioide e relações maxilo-mandibulares. O protocolo de aquisição das Imagens por RM incluiu sequências sagitais de alta definição anatômica, ponderadas em T1, realizadas inicialmente com o paciente em vigília e durante o sono induzido por Propofol. Para este estudo, foram selecionadas as imagens de boa resolução no plano sagital, com o paciente acordado e dormindo. A região avaliada foi definida no plano sagital na linha média da faringe, tendo como limite superior uma linha que passa pelo palato duro até a parede posterior da faringe, e como limite inferior, a valécula; posteriormente à parede posterior da faringe e anteriormente à base da língua e o palato mole. Foi realizada a avaliação no plano sagital, com o paciente deitado, com o objetivo de comparar as áreas estudadas $\left(\mathrm{mm}^{2}\right)$ no mesmo paciente acordado e dormindo, no pré e pós-operatório. A análise do volume $\left(\mathrm{mm}^{3}\right)$ foi realizada pela somatória das áreas, multiplicada pela espessura da mesma, sem intervalo entre os cortes. O espaço aéreo faríngeo da região compreendida entre o palato duro e a base da epiglote foi dividido em região retropalatal (RP) e retrolingual (RL). A análise dinâmica foi realizada pela sequência temporal, vista como um filme, quadro a quadro, com 30 imagens, com análise da mobilidade das vias aéreas após a indução do sono. Também foram realizadas nas 30 imagens medidas da distância linear $(\mathrm{mm})$ entre a base da língua e a parede posterior da faringe, no nível do bordo inferior da segunda vértebra (C2). Resultados: Os resultados da cefalometria mostraram que cada mm de 
avanço ósseo maxilo-mandibular resultou em 1,2 mm de aumento da faringe na região retrolingual, e de $0,76 \mathrm{~mm}$ na região retropalatal. No exame de RM realizado durante a vigília, cada mm linear de avanço maxilo-mandibular resultou em aumento médio volumétrico de toda a faringe (região retrolingual e retropalatal) em aproximadamente 4,5\%. A CAMM promoveu aumento significativo $(\mathrm{p}<0,01)$ do volume da faringe de aproximadamente $26,5 \%$ durante a vigília. Durante o sono induzido e na vigília, a CAMM resultou em significativo aumento médio $(\mathrm{p}<0,001)$ de aproximadamente $33 \%$ da área da faringe. $\mathrm{O}$ valor mínimo da área da faringe durante o sono induzido após a realização da CAMM é 2,3 vezes maior que o valor mínimo da área medido no pré-operatório. O aumento linear médio ântero-posterior da faringe durante o sono induzido após a realização da CAMM foi de 66\% na região RL. Conclusão: A CAMM promoveu aumento significativo da faringe em medidas bidimensionais (cefalometria) e tridimensionais (Ressonância Magnética), sendo que durante o sono induzido gerou manutenção de uma abertura da via aérea e promoveu menor variação em seu diâmetro, resultando em maior estabilidade e menor possibilidade de colabamento, o que contribuiu para a diminuição dos eventos obstrutivos.

\title{
DESEMPENHO DE IDOSOS COM E SEM DOENÇA DE ALZHEIMER EM TESTES AUDITIVOS CENTRAIS: ESTUDO COMPARATIVO
}

\author{
Alina Sanches Gonçales \\ Orientadora: Profa. Dra. Maria Cristina Lancia Cury \\ Tese de Doutorado apresentada em 15/10/2010
}

A doença de Alzheimer é uma doença neurodegenerativa progressiva que afeta as funções cognitivas do paciente. Em seus estágios iniciais, a doença raramente é diagnosticada. Três fatores podem justificar os déficits de compreensão de fala em idosos: a perda auditiva periférica, o envelhecimento das vias auditivas centrais e as mudanças cognitivas características do envelhecimento. Avaliações auditivas centrais podem contribuir para o diagnóstico diferencial entre a doença de Alzheimer e outras alterações próprias do envelhecimento. O presente estudo teve como objetivo caracterizar o desempenho de pessoas com e sem doença de Alzheimer em testes comportamentais de processamento auditivo e P300. Foram avaliados 38 sujeitos, com idades entre 51 e 77 anos, sendo 16 com doença de Alzheimer e 22 sem a doença. Todos os participantes tinham, no máximo, perda neurossensorial leve, índice percentual de reconhecimento de fala maior ou igual a $80 \%$ e ausência de queixas quanto à compreensão de fala. Foram realizados os testes de Fala com Ruído, Dicótico de Dissílabos Alternados (SSW) e P300. Os resultados mostraram diferença estatística entre os grupos para os dois testes de processamento auditivo realizados. Houve pior desempenho da orelha esquerda, no teste dicótico, para os dois grupos, porém a assimetria foi mais evidente nos pacientes com doença de Alzheimer. Não houve diferença estatística para a latência do P300. Houve diferença estatística da amplitude da onda P300 entre o dois grupos. Conclui-se que os testes auditivos centrais podem ser utilizados como procedimentos auxiliares no diagnóstico da doença de Alzheimer e contribuir para a compreensão das dificuldades de comunicação desses pacientes.

\section{ESTUDO MORFOMÉTRICO ENDOSCÓPICO DA FARINGE EM PACIENTES PORTADORES DA SÍNDROME DA APNEIA E HIPOPNEIA OBSTRUTIVA DO SONO TRATADOS COM CIRURGIA DE AVANÇO MAXILOMANDIBULAR}

\author{
Sávio Noqueira da Silva Júnior \\ Orientador: Prof. Dr. Francisco Veríssimo de Mello-Filho \\ Tese de Doutorado apresentada em 30/11/2010
}

Em amostra de 18 pacientes com SAHOS de grau leve a severo, que foram submetidos à cirurgia de avanço maxilomandibular, avaliou-se endoscopicamente a faringe no pré e pós-cirúrgico. Foram verificadas as modificações nas seguintes situações: vigília sentado e deitado respirando naturalmente, com manobras de Müller e Müller modificado, bem como em sono induzido em decúbito dorsal respirando naturalmente. Os exames de nasofibrolaringoscopia da faringe foram gravados em DVD e, por meio do programa de computador Sony Vegas 8.0, foram capturadas imagens da faringe na região retro-lingual no pré e pós-operatório, em menor abertura, maior abertura, Müller, canudo 1 e canudo 2 . A seguir foi utilizado outro programa, o Image $J$, para obter medidas de áreas, linear ântero-posterior, linear da borda da epiglote à base da língua, linear da borda da epiglote à parede posterior da faringe e linear látero-lateral, para compará-las entre si. Os achados do presente estudo mostraram que as dimensões da faringe sempre aumentaram de modo significativo em todas as medidas, quando os pacientes foram comparados no pré e pós-operatório. Quando em vigília, sentado e deitado, 
observou-se que o maior ganho ocorreu na medida de área quando realizada a manobra de Müller modificada. Quando em sono induzido em decúbito dorsal, verificou-se que a abertura faríngea sempre aumentou e de maneira mais acentuada em todas as medidas; ocorrendo maior aumento na medida de área na menor abertura (201,33\%). As dimensões ânteroposterior e látero-lateral também aumentaram em todas as suas medidas, sendo que a maior expressão ocorreu também com o paciente em sono induzido na menor abertura com 124,90\% e 76,59\%, respectivamente. Concluiu-se que a medida de área é a mais importante a ser observada e sugere que tanto a melhora da dimensão quanto do colapso da faringe pode explicar o sucesso da cirurgia do avanço maxilomandibular.

\title{
O PISCAR ESPONTÂNEO EM SUJEITOS NORMAIS E PACIENTES COM RETRACÃO PALPEBRAL POR ORBITOPATIA DE GRAVES
}

\author{
Carolina Trindade Pinto \\ Orientador: Prof. Dr. Antonio Augusto Velasco e Cruz \\ Tese de Doutorado apresentada em 02/12/2010
}

Foram medidos em sujeitos normais e pacientes com orbitopatia de Graves, com a técnica do magnetic search coil, os seguintes parâmetros do piscar espontâneo: taxa e distribuição temporal das piscadelas, amplitude, velocidade e duração da fase descendente e ascendente dos movimentos da pálpebra superior. No experimento 1, esses parâmetros foram medidos em 15 indivíduos de cada grupo durante 5 minutos. Os resultados mostraram que os pacientes apresentaram menor taxa de piscadelas quando comparado ao grupo controle. Diferentes padrões de distribuição do tempo entre as piscadelas foram encontrados nos dois grupos. Em valores absolutos não houve diferença na amplitude entre os controles e pacientes. Entretanto, quando o valor da amplitude foi normalizado pela medida da altura da pálpebra superior observou-se que os movimentos de piscar dos pacientes eram menos efetivos. $\mathrm{O}$ estudo da relação entre velocidade e amplitude de cada integrante da amostra (main sequence) não foi possível devido ao número exíguo de movimentos palpebrais em alguns pacientes. O segundo experimento foi realizado em 10 sujeitos normais e 10 pacientes durante 1 hora. Nesse caso, não houve diferença significativa entre os dois grupos quanto à frequência, velocidade e amplitude das piscadelas. Todas as distribuições de tempo entre as piscadelas foram positivamente assimétricas sendo bem ajustadas por uma curva do tipo log-normal. A efetividade do piscar dos pacientes também foi menor do que a do grupo controle. Com o tempo maior de observação e consequentemente maior número de movimentos de piscar foi possível caracterizar a relação entre a amplitude e a velocidade que foi linear em todos os sujeitos testados. O valor médio da inclinação da reta dessa relação foi ligeiramente menor nos pacientes do que nos sujeitos normais. A duração da fase descendente dos pacientes tende a ser maior do que a dos controles em maiores amplitudes, o mesmo não foi observado na fase ascendente.

\section{ESTUDO DA RELAÇÃO ESCAVAÇÃO/NERVO ÓPTICO PELO EXAME DE ULTRASSOM MODO B DE ALTA RESOLUÇÃO COM SONDA DE 20 MEGAHERTZ}

\author{
Wiliam Silva Queiroz \\ Orientador: Prof. Dr. Jayter Silva de Paula \\ Dissertação de Mestrado apresentada em 08/12/2010
}

Objetivo: Verificar a correlação entre os achados da relação escavação/ diâmetro do nervo óptico retrobulbar (E/ DNO) obtidos pelo exame de ultrassonografia modo B de alta resolução com sonda de 20 Megahertz (MHz) e a relação escavação/cabeça do nervo óptico (E/CNO) obtidos pela biomicroscopia de fundo de olho (BIO) e pela tomografia de coerência óptica (OCT). Métodos: Foram analisados 30 olhos de 15 pacientes com diagnóstico de glaucoma primário de ângulo aberto (GPAA), com qualquer proporção da relação E/CNO. Todos os pacientes foram submetidos ao exame de BIO e OCT para a análise da relação E/CNO e exame de ultrassonografia (US) modo B, com sonda de 20 MHz, para determinação da proporção E/DNO. Todos os resultados foram analisados por métodos de correlação. Resultados: Observou-se forte correlação entre as medidas E/CNO (BIO) e as medidas E/DNO (US) ( $\mathrm{r}=0,788 ; \mathrm{P}<0,0001$ ), assim como, entre as medidas E/ CNO (BIO) e (OCT) (r=0,8529; P<0,0001). Porém, a análise da relação entre as medidas E/DNO (US) e E/CNO (OCT) mostrou apenas níveis moderados de correlação $(\mathrm{r}=0,6727, \mathrm{P}<0,0001)$. Também se observou baixa concordância na análise gráfica de Bland-Altman para as variáveis E/DNO (US) e E/CNO (BIO). Conclusão: O exame de US modo B com sonda de $20 \mathrm{MHz}$ mostrou-se um bom método para avaliar escavação do nervo óptico em pacientes com glaucoma, com base na forte correlação observada com o exame de biomicroscopia de fundo de olho, e pode constituir uma ferramenta adicional na avaliação de pacientes glaucomatosos com opacidades dos meios ópticos. 


\title{
ESTUDO COMPARATIVO DO EFEITO ANALGÉSICO USANDO TRÊS DIFERENTES TÉCNICAS ANESTÉSICAS PARA INJEÇÃO INTRAVÍTREA DE BEVACIZUMABE
}

\author{
Levy da Rocha Lucena \\ Orientador: Prof. Dr. Rodrigo Jorge \\ Tese de Doutorado apresentada em 10/12/2010
}

O objetivo deste estudo foi comparar a eficácia analgésica e a aparência estética, avaliando a hemorragia subconjuntival, associada com as anestesias tópica, subconjuntival e peribulbar para a realização de injeção intravítrea de bevacizumabe. Sessenta pacientes com indicação de injeção intravítrea de bevacizumabe (primeira aplicação) foram randomizados para receber uma entre três tipos de anestesia: colírio de proximetacaína (grupo TÓPICA; $n=20$ ), injeção subconjuntival de xilocaína 2\% (grupo SUBCONJUNTIVAL; $\mathrm{n}=20$ ), e injeção peribulbar de xilocaína 2\% (grupo PERIBULBAR; $\mathrm{n}=20$ ). A dor associada com a injeção intravítrea e com o procedimento como um todo (incluindo a administração anestésica) foi avaliada usando a escala analógica visual 15 minutos após a injeção intravítrea. Essa escala varia de 0 a 100, onde zero representa "ausência total de dor", e 100 representa "a dor mais intensa que poderia sentir". Foi realizada avaliação do segmento anterior 24 horas pós-injeção para mensurar, em horas de relógio, a hemorragia subconjuntival. As mensurações principais incluíram: dor relacionada à injeção intravítrea (DRI), dor de todo o procedimento (DTP), e horas de relógio de hemorragia subconjuntival (HSC).

Os valores das medianas da DRI para os grupos TÓPICA, SUBCONJUNTIVAL e PERIBULBAR foram: cinco (0 $22)$; três $(0$ - 25) e zero $(0$ - 11), respectivamente $(\mathrm{p}=0.002)$. O valor da mediana da DRI foi significativamente mais baixa no grupo PERIBULBAR comparado com os grupos TÓPICAe SUBCONJUNTIVAL $(\mathrm{p}<0.05)$, sem diferença significante entre os dois últimos grupos. Os valores das medianas da DTP para os grupos TÓPICA, SUBCONJUNTIVAL e PERIBULBAR foram: cinco (0 - 25); $4.45(0$ - 27) e $9.5(2$ - 30), respectivamente $(\mathrm{p}=0.012)$. O valor da mediana da DTP foi significativamente mais alto no grupo PERIBULBAR comparado com os grupos TÓPICA e SUBCONJUNTIVAL ( $p<0.05$ ), sem diferença significante entre os dois últimos grupos. As medianas de HSC nos grupos TÓPICA, SUBCONJUNTIVAL e PERIBULBAR foram: um (0 - 2), quatro (2 - 12), e três $(1-7)$, respectivamente ( $\mathrm{p}<0.0001)$. A mediana de extensão do HSC foi significativamente mais baixa no grupo TÓPICA comparada com os outros grupos $(\mathrm{p}<0.05)$.

O estudo demonstrou que a anestesia tópica, entre as três técnicas anestésicas avaliadas, foi a mais eficiente em controlar a intensidade da dor durante todo o procedimento envolvendo a realização da injeção intravítrea de bevacizumabe, associada à melhor aparência estética após o procedimento, ou seja, menor taxa de hemorragia subconjuntival, sugerindo que pode ser considerada a técnica anestésica de escolha para a maioria dos pacientes que se submeterão à injeção intravítrea.

\section{RANIBIZUMABE INTRAVÍTREO NO PRÉ-OPERATÓRIO DE VITRECTOMIA VIA pars plana EM PACIENTES DIABÉTICOS COM DESCOLAMENTO DE RETINA TRACIONAL}

\author{
Jefferson Augusto Santana Ribeiro \\ Orientador: Prof. Dr. Rodrigo Jorge \\ Tese de Doutorado apresentada em 10/12/2010
}

Objetivos: Investigar os efeitos do ranibizumabe intravítreo (IVR) no sangramento intraocular durante vitrectomia via pars plana (VVPP) 23-gauge para descolamento de retina tracional (DRT) em pacientes diabéticos. Métodos: Trata-se de estudo prospectivo, duplo mascarado, envolvendo 18 olhos consecutivos com retinopatia diabética proliferativa (RDP), que foram submetidos à VVPP para DRT envolvendo a mácula de até três meses de duração. Os pacientes foram aleatoriamente designados para 0,5 mg IVR (grupo RANI/PPV, $n=9$ ) ou injeção simulada (grupo PPV, $n=9$ ) uma semana antes do VVPP. Todos os pacientes completaram 12 semanas de acompanhamento após a VVPP. A hemorragia intraocular durante a cirurgia foi medida pela contagem do número de hemácias no líquido obtido do reservatório do equipamento de vitrectomia ao final do procedimento. Resultados: A média \pm EPM da contagem de eritrócitos ( $* 10^{6}$ células) foi $63,2 \pm 25,2$ para o grupo RANI/PPV, e 185,1 \pm 49,2 para o grupo PPV ( $\mathrm{p}=0,0192$, Wilcoxon). Não houve alteração estatisticamente significativa na acuidade visual do grupo RANI/PPV; mas melhora de $0,35 \pm 0,1 \operatorname{logMAR}(\mathrm{p}<0,05)$ foi observada no grupo PPV 12 semanas após a cirurgia. Conclusão: A administração de ranibizumabe intravítreo esteve associada à redução da hemorragia intraocular durante a VVPP em olhos com DRT envolvendo a mácula, secundária à RDP, podendo contribuir, assim, para uma cirurgia segura e tecnicamente mais fácil. Estudos posteriores com maior número de pacientes serão necessários para avaliar se o IVR pré-operatório afeta a função visual em longo prazo. 


\title{
EFEITO DA EXPANSÃO RÁPIDA DA MAXILA SOBRE A NASOFARINGE E O VOLUME NASAL: AVALIAÇÃO POR RESSONÂNCIA MAGNÉTICA E RINOMETRIA ACÚSTICA
}

\author{
Fernanda Weber de Morais Gallarreta \\ Orientadora: Profa. Dra. Wilma T. Anselmo-Lima \\ Tese de Doutorado apresentada em 15/12/2010
}

A mordida cruzada posterior é uma das maloclusões frequentemente encontrada em pacientes respiradores bucais e a expansão rápida da maxila é o procedimento ortodôntico/ortopédico mais utilizado para a sua correção. O objetivo deste estudo foi avaliar a área da nasofaringe, por meio da ressonância magnética, e o volume da cavidade nasal, pela rinometria acústica, antes e após a expansão rápida da maxila. Foram selecionadas trinta crianças com respiração bucal e/ ou mista, de ambos os gêneros, na faixa etária de 07 a 10 anos de idade, em fase de dentição mista, portadoras de mordida cruzada posterior, uni ou bilateral, envolvendo caninos e molares decíduos e primeiros molares permanentes, sem qualquer tipo de tratamento otorrinolaringológico ou ortodôntico. Os exames rinológicos, a ressonância magnética e as documentações ortodônticas foram realizadas antes e 180 dias após a expansão. Os resultados mostraram que houve um aumento estatisticamente significante tanto da área da nasofaringe como do volume nasal após a expansão rápida da maxila; houve correlação positiva entre as áreas da nasofaringe pré e pós expansão, porém não houve correlação entre a área e o volume nasal. Pode-se concluir que a expansão rápida da maxila pode promover alterações tanto na região da nasofaringe como no volume da cavidade nasal em pacientes com respiração bucal e/ou mista.

\section{IMPLICAÇÕES FISIOPATOLÓGICAS DA AVALIAÇÃO OCULAR MULTIMODAL EM DISTROFIA MACULAR VITELIFORME DE BEST}

\author{
Daniela Cavalcanti Ferrara de Almeida Cunha \\ Orientador: Prof. Dr. Rogério Alves Costa \\ Tese de Doutorado apresentada em 16/12/2010
}

Introdução: A distrofia macular viteliforme de Best (DMVB) é rara doença autossômica dominante de expressão fenotípica muito variável. Interpretações dos mecanismos fisiopatológicos da doença baseadas em histopatologia, eletrofisiologia, análise genética e estudos por imagem são discordantes em aspectos fundamentais, tais como a localização e a extensão das alterações morfológicas primárias da retina. O presente estudo descreve os aspectos morfológicos da mácula em pacientes com DMVB utilizando a avaliação ocular multimodal simultânea, e os compara com os de sujeitos normais pareados por idade. Métodos: Estudo comparativo incluindo sete pacientes com DMVB (14 olhos) e sete sujeitos normais pareados por idade (14 olhos). Todos os participantes foram submetidos a exame oftalmológico completo, fotografias de fundo, e protocolo padronizado de avaliação ocular multimodal incluindo tomografia de coerência óptica espectral (TCOe) combinada com reflectância de fundo com luz "infravermelha" e autofluorescência de fundo com luz azul (AFa). Resultados: Em dois olhos no estágio subclínico da doença, a TCOe revelou espessamento de camada altamente refletiva (CAR) média, localizada entre a junção dos segmentos externo e interno de fotorreceptores (CAR interna) e o complexo refletivo formado pelo epitélio pigmentado da retina (EPR) e a membrana de Bruch (CAR externa), por toda a mácula. Em um olho no estágio viteliforme, observou-se material homogêneo hiperrefletivo à TCOe entre a CAR média e a CAR externa, apresentando aumento de autofluorescência à AFa. A camada nuclear externa (CNE) mostrou-se afinada na região macular central, e acúmulo de fluido subretiniano não foi identificado não nestes estágios iniciais da doença. Em pacientes nos estágios de pseudohipópio (dois olhos), vitelirruptivo (oito olhos), e atrófico (um olho), a TCOe revelou uma variedade de alterações na CAR média e na CAR externa, e afinamento da CNE. Estas alterações se mostraram associadas ao nível de acuidade visual observado. Espessamento da CAR média foi observado além dos limites da lesão macular clinicamente evidente, em todos os olhos. Conclusão: A avaliação ocular multimodal demonstrou espessamento da camada refletiva correspondente aos segmentos externos de fotorreceptores por toda a mácula, sem acúmulo de fluido subretiniano associado, como o primeiro achado detectável em DMVB. Alterações identificadas nas camadas refletivas de fotorreceptores (CAR média e CAR interna) e afinamento da CNE parecem ser progressivas, com implicações diretas para os níveis de deficiência visual observados nos diferentes estágios da doença. 


\title{
Ortopedia, Traumatologia E Reabillitação
}

\section{TERAPIA DE USO FORÇADO PRODUZ GANHOS FUNCIONAIS NA MARCHA E EQUILÍBRIO DO PACIENTE HEMIPARÉTICO: PROTOCOLO E SEGUIMENTO}

\author{
Amanda Cunha Fuzaro \\ Orientador: Prof. Dr. João Eduardo de Araújo \\ Dissertação de Mestrado apresentada em 01/10/2010
}

O Acidente Vascular Encefálico (AVE) é a segunda causa de óbitos no mundo e a grande causa de dependência em adultos a longo prazo, por ser a principal causa de incapacidades físicas e cognitivas. Para a reabilitação motora, têm sido propostos métodos que objetivam reverter o desuso aprendido, uma alteração fisiopatológica que impede a utilização de segmentos que ficaram em situação de imobilidade por um grande período de tempo. Esse trabalho se propôs a verificar se a Terapia de Uso Forçado (TUF), uma terapia utilizada na reabilitação de membros superiores (MS) paréticos, pode proporcionar ganhos no equilíbrio e na marcha. Ainda, verificar se a melhora do padrão motor se mantém incorporado à organização neural do movimento após 1, 2 e 3 meses da conclusão do protocolo. Participaram deste estudo 18 indivíduos de ambos os sexos, que sofreram AVE e que apresentaram hemiparesia como sequela motora. A imobilização do MS não parético foi feita através de uma malha tubular, por um período de 24 horas, durante 5 dias por semana, por uma período total de 4 semanas. Foram realizadas oito avaliações: inicial, intermediárias (com 1, 23 e 4 semanas de tratamento) e seguimento (1, 2 e 3 meses após o término do protocolo). Na admissão dos sujeitos foi utilizada a escala: National Institute of Health Stroke Scale (NIHSS). A funcionalidade e equilíbrio dos MMII foram avaliados pelas escalas de Wolf Motor Function Test (WMFT), Berg Balance Scale (BBS) e Fugl-Meyer Motor Assesment (FMA). Para a análise da marcha foi utilizado o Teste dos 10 metros (T10) e o Timed Up \& Go Test (TUGT). Os dados foram submetidos a uma análise de variância de uma via (ANOVA) e as diferenças entre os grupos foram evidenciadas através do teste post hock de HolmSidak com valor de $\mathrm{p}<0,05$. A comparação dos dados com 4 semanas, 1, 2 e 3 meses para a escala admissional NIHSS, mostrou uma diminuição significativa da pontuação $\left(\mathrm{F}_{4,84}=8,098\right)$ em relação á avaliação inicial. Na mesma direção, a comparação de 1, 2, 3 e 4 semanas, 1, 2 e 3 meses revelou aumentos significativos na performance motora dos sujeitos em relação à inicial através da escala de WMFT nos itens tempo e pontos $\left(\mathrm{F}_{7,138}=7,472\right) \mathrm{e}\left(\mathrm{F}_{7,138}=7,041\right)$ respectivamente, e isso também foi revelado pela escala FMA $\left(\mathrm{F}_{7,130}=4,697\right)$ e BBS $\left(\mathrm{F}_{7,138}=2,280\right)$. Ainda, verificamos uma diminuição do tempo necessário para a execução do T10 e no TUGT $\left(\mathrm{F}_{7,138}=2,878\right)$ e $\left(\mathrm{F}_{7,138}=3,976\right)$, respectivamente. Os resultados sugerem que a TUF é eficaz na reabilitação do equilíbrio e da marcha de pacientes hemiparéticos e que os ganhos funcionais se mantém após o término do protocolo de estimulação.

\section{AVALIAÇÃO ULTRASSONOMÉTRICA in vitro DA OSTEOTOMIA TRANSVERSAL DA TÍBIA DE OVELHAS FIXADAS COM PLACA DE COMPRESSÃO}

\author{
Márcio Takey Bezuti \\ Orientador: Prof. Dr. Cláudio Henrique Barbieri \\ Dissertação de Mestrado apresentada em 05/10/2010
}

O estudo in vitro compara diferentes formas de medidas ultrassonométricas ósseas, na avaliação da osteotomia do osso cortical médio diafisária da tíbia de carneiro fixado com placa de compressão dinâmica em diferentes estágios. Foram utilizados 10 segmentos de tíbia de carneiro sendo realizadas medidas de velocidade do ultrassom pelo modo axial na face lateral dos ossos, modos transversais no sentido sagital e coronal, contato direto com gel de acoplamento e subaquático em tanque acústico. Estas medidas foram realizadas nos ossos íntegros, após a colocação da placa e osteotomia e após a compressão dinâmica. Os resultados demonstraram diferença na velocidade entre os modos de contato sendo maior no subaquático e com relação ao plano de medida foi mais rápido no sentido sagital. A presença do implante não alterou a velocidade de condução, já a presença da osteotomia levou a uma diminuição da velocidade que retornou a inicial após a compressão interfragmentária. Todas estas diferenças foram significativas para pd $£ 0,01$ nas comparações. Concluiu-se que o método da ultrassonometria sofre variação conforme o modo e sentido de aplicação assim como a presença de um espaço criado pela osteotomia. O implante ortopédico alterou de forma detectável a velocidade de condução do ultrassom porém sem correlação estatística. 


\title{
FUNÇÃO PULMONAR E EFEITOS DO FLUTTER VRP1 EM PACIENTES COM BRONQUIECTASIA
}

\author{
Rita de Cássia Passarelli \\ Orientadora: Profa. Dra. Ada Clarice Gastaldi \\ Dissertação de Mestrado apresentada em 18/10/2010
}

Introdução: Bronquiectasia é uma doença obstrutiva, com hipersecreção e comprometimento clínico e funcional heterogêneo. A fisioterapia respiratória tem por objetivo aumentar a remoção das secreções das vias aéreas e diminuir a obstrução para melhorar a ventilação pulmonar e as trocas gasosas. O FLUTTER VRP1 é um equipamento que combina duas técnicas: pressão expiratória positiva (PEP), e oscilações de alta frequência, coadjuvantes no tratamento e prevenção do colapso alveolar e na eliminação das secreções pulmonares. Objetivo: Avaliar a efetividade do FLUTTER VRP1 sobre a função pulmonar, através da espirometria, em pacientes portadores de bronquiectasia. Metodologia: 37 pacientes com bronquiectasia realizaram avaliação e espirometria. 8 pacientes participaram das intervenções, em estudo randomizado e cruzado. Intervenção 1: terapia com FLUTTER VRP1 (grupo 1) ou exercício com a técnica sham-FLUTTER (grupo 2). Intervenção 2: FLUTTER VRP1 (grupo 1) e PEP (grupo 2), durante 30 minutos, por 4 semanas de tratamento e 1 semana de "wash-out", seguida de mais 4 semanas com a outra modalidade. Resultados: Dos 37 pacientes avaliados, 21 apresentaram dispnéia e tiveram valores menores de VEF1 $(1,19 \pm 0,52 \mathrm{~L} ; 44,86 \pm 21,12 \%)$, VEF1/CVF $(0,54 \pm 0,31 ; 64,86 \pm 25,29 \%)$ e FEF25$75 \%(0,66 \pm 0,58 \mathrm{~L} / \mathrm{s} ; 25,05 \pm 22,65 \%)$, que os sem dispnéia (VEF1:2,03 $\pm 0,81 \mathrm{~L} ; 70,94 \pm 30,31 \%$, VEF1/CVF: $0,73 \pm 0,11 ; 87,13 \pm 15,71 \%$ e FEF25-75\%: 1,89 $\pm 1,20 \mathrm{~L} / \mathrm{s} ; 63,19 \pm 40,58 \%)(\mathrm{p}<0,05)$. Na intervenção 1 : sham-FLUTTER vs FLUTTER VRP1, obtivemos valores menores de CVF $(2,47 \pm 0,73 \mathrm{~L} \mathrm{e} 79,25 \pm 21,29 \%)$ e de VEF1 $(1,66 \pm 0,86 \mathrm{~L}$ e $64,50 \pm 29,87 \%)$ para o grupo FLUTTER VRP1 $(\mathrm{p}<0,05)$ comparado ao controle (CVF: 2,59 $\pm 0,78 \mathrm{~L} \mathrm{e} 82,38 \pm 22,19 \%$; VEF1: 1,76 $\pm 0,95 \mathrm{~L}$ e $67,38 \pm 31,59 \%$ ) e ao sham-FLUTTER

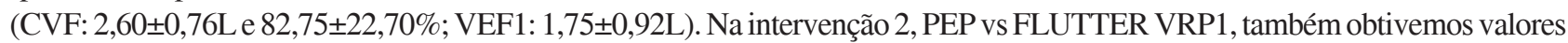
menores de CVF $(2,44 \pm 0,75 \mathrm{~L} ; 79,00 \pm 21,31 \%)$; VEF1 (1,56 $\pm 0,88 \mathrm{~L} ; 60,88 \pm 29,47 \%)$; FEF25-75\% (1,36 $\pm 1,34 \mathrm{~L} ; 45,75 \pm 41,11 \%)$ para o grupo FLUTTER VRP1 (p<0,05) comparado ao controle (CVF: 2,57 $\pm 0,79 \mathrm{~L} ; 82,63 \pm 22,18 \%$; VEF1: 1,68 $\pm 0,97 \mathrm{~L}$;

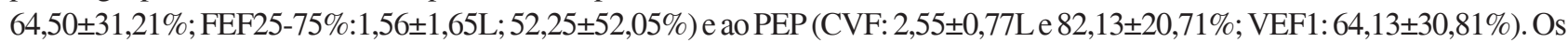
valores de FEF25-75\% (valor absoluto e \%) foram maiores para o controle em relação ao PEP (p<0,05). Conclusão: Os pacientes que referiram dispnéia durante as atividades de vida diária demonstraram maior comprometimento da função pulmonar. A eficácia dos exercícios com FLUTTER VRP1 precisa ser melhor estabelecida pois a utilização do dispositivo pode prejudicar a função pulmonar.

\section{FORÇA MUSCULAR RESPIRATÓRIA E EFEITOS DO FLUTTER VRP1 EM PACIENTES COM BRONQUIECTASIA}

\section{Roberta Marques Lisboa}

Orientadora: Profa. Dra. Ada Clarice Gastaldi

Dissertação de Mestrado apresentada em 26/10/2010

Introdução: A bronquiectasia é uma doença caracterizada por inflamação, dilatação, hipersecretividade e uma lesão obstrutiva dos pulmões. Os acúmulos de secreção associada às alterações no parênquima pulmonar interferem na mecânica ventilatória, diminuindo os volumes e capacidades pulmonares, devido a hiperinsuflação dinâmica, que promove uma sobrecarga à musculatura respiratória, o que gera um processo de fadiga dos músculos. A força muscular respiratória é mensurada através das medidas de pressão inspiratória máxima (PImáx) e pressão expiratória máxima (PEmáx).Os músculos respiratórios podem ser treinados visando o aumento da força e endurance, através da reabilitação pulmonar realizada pela fisioterapia respiratória. A fisioterapia respiratória utiliza recursos que removem das secreções das vias aéreas, diminuem a obstrução e melhoram a ventilação pulmonar e as trocas gasosas. O FLUTTER VRP1 é um equipamento que combina duas técnicas: oscilações de alta frequência, coadjuvantes no tratamento e prevenção do colapso alveolar e na eliminação das secreções pulmonares e pressão expiratória positiva (PEP) que promove uma resistência com baixa carga durante a expiração. Objetivo: Avaliar a força muscular respiratória antes e após terapia com Flutter VRP1 como um exercício com baixa resistência expiratória, em pacientes portadores de bronquiectasia. Metodologia: Foram avaliados 37 pacientes com bronquiectasia e 9 pacientes participaram dos protocolos, em estudo randomizado e cruzado. Protocolo 1: terapia com Flutter VRP1 X SHAM. Protocolo 2: Flutter VRP1 XPEP durante 30 minutos, por 4 semanas de tratamento e 1 semana de "wash-out", seguida de mais 4 semanas com a outra modalidade. Resultados: Avaliação: a média dos valores absolutos de PImáx obtido pelos homens foi de $-89,47(+29,88) \mathrm{cmH}_{2} \mathrm{O}$ e os previstos pela equação de Black e Hyatt $(\mathrm{BH})$ 
foi -112,81 (+7,31) $\mathrm{cmH}_{2} \mathrm{O}$ e por Neder $(\mathrm{N})-111,39(+29,88) \mathrm{cmH}_{2} 0$. A média do valor de PImáx obtido pelas mulheres foi de $-76,20(+24,56) \mathrm{cmH}_{2} \mathrm{O}$ e o previsto pela equação de $\mathrm{BH}$ foi -78,22 $(+9,07) \mathrm{cmH}_{2} \mathrm{O}$ e por $\mathrm{N}-85,63(+8,72) \mathrm{cmH}_{2} 0$. A média da PEmáx obtida pelos homens foi de 121,53 (+33,70) $\mathrm{cmH}_{2} \mathrm{O}$ e o previsto pela equação de $\mathrm{BH}$ foi $211,47(+13,70) \mathrm{cmH}_{2} \mathrm{O}$ e por $\mathrm{N} 120,85(+10,77) \mathrm{cmH}_{2}$. A média da PEmáx obtida pelas mulheres foi de $88,70(+25,10) \mathrm{cmH}_{2} \mathrm{O}$ e o previsto pela equação de BH foi 143,21 $(+9,43) \mathrm{cmH}_{2} \mathrm{O}$ e por $\mathrm{N} 84,76(+10,85) \mathrm{cmH}_{2} 0$. Protocolo 1: A média dos valores obtidos pelo grupo (homens e mulheres)foi: Avaliação (PImáx -90,9 $\mathrm{cmH}_{2} \mathrm{O}$ e PEmáx 118,5 $\mathrm{cmH}_{2} \mathrm{O}$ ), após quatro semanas de terapia com Flutter (PImáx 87,32 cmH $\mathrm{cm}_{2} \mathrm{O}$ PEmáx 118,29 $\mathrm{cmH}_{2} \mathrm{O}$ ) ou Sham (PImáx -92,11 cmH $\mathrm{cm}_{2} \mathrm{O}$ e PEmáx 125,65 cmH $\mathrm{cm}_{2} \mathrm{O}$. Protocolo 2: A média dos valores obtidos pelo grupo foi: Avaliação (PImáx -89,92 $\mathrm{cmH}_{2} \mathrm{O}$ e PEmáx 116,75 $\mathrm{cmH}_{2} \mathrm{O}$ ), após quatro semanas de terapia

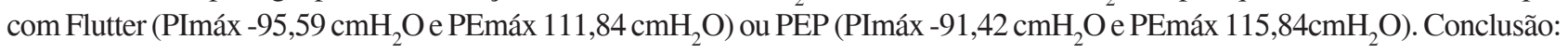
Os pacientes com bronquiectasia apresentam a força dos músculos respiratórios preservada, mesmo aqueles com presença de dispnéia e expectoração.O exercício com Flutter VRP1 realizado de modo não forçado não altera a força dos músculos respiratórios. Novos estudos devem ser realizados com os pacientes com bronquiectasia, relacionados ao treinamento muscular respiratório e a reabilitação pulmonar.

\title{
VALIDAÇÃO DO ESPAÇO SUBACROMIAL RADIOGRÁFICO COMO UM INDICATIVO DE DIAGNÓSTICO DA SÍNDROME DO IMPACTO SUBACROMIAL
}

\author{
Guilherme de Carvalho Spósito \\ Orientadora: Profa. Dra. Anamaria Siriani de Oliveira \\ Dissertação de Mestrado apresentada em 27/10/2010
}

Objetivos: verificar a confiabilidade intra e interexaminador da mensuração do índice de impacto subacromial (IIS) radiográfico, além de realizar sua correlação com testes ortopédicos específicos do complexo articular do ombro e com a avaliação por imagem do manguito rotador, analisando a validade para auxiliar o diagnóstico clínico da SIS. Materiais e Métodos: foi selecionado um grupo de 30 indivíduos com SIS e um grupo controle composto por 29 indivíduos saudáveis. Foi realizada avaliação física para a aplicação dos testes ortopédicos específicos do complexo do ombro, exame de imagem do manguito rotador por ultrassonografia e exame radiográfico para obtenção e mensuração do IIS. As imagens radiográficas foram obtidas com incidência ântero-posterior e inclinação crânio-caudal de $30^{\circ}$, os voluntários permaneceram sentados, sustentando o próprio peso do membro superior contra a gravidade a $90^{\circ}$ de abdução no plano frontal, com o ombro em rotação neutra. Um paquímetro digital foi utilizado para realizar as mensurações e o valor do IIS foi determinado pelo espaço subacromial dividido pelo colo anatômico do úmero. Resultados: o IIS é uma medida confiável tanto intra quanto interexaminador, com valores de ICC de pelo menos 0,96 e 0,94 respectivamente. Houve diferença significativa $(p=0,02)$ entre os grupos controle e com SIS, sendo que a média do grupo controle $(0,12 \pm 0,05)$ foi maior que a do grupo com SIS $(0,09 \pm 0,04)$. Quanto à avaliação física, os valores do IIS encontrados nos testes positivos de Jobe e "Rotação lateral" foram estatisticamente menores que os encontrados nos negativos ( $\mathrm{p} d \leq 0,04$ ). Em relação ao exame de ultrassom, observamos que não houve diferenças significativas do IIS independente do grau de integridade do manguito rotador. No entanto, o IIS variou significativamente quando levamos em consideração a sintomatologia clínica, sendo observadas diferenças entre lesões sintomáticas e assintomáticas. Conclusão: o IIS radiográfico proposto pelo estudo é uma medida confiável, sendo que os valores de indivíduos com SIS são estatisticamente menores quando comparados a indivíduos saudáveis, apresentando correlação com a integridade do manguito rotador apenas quando os sintomas clínicos são levados em consideração. Entretanto, não é possível estipular valores quantitativos do IIS radiográfico que possam ser utilizados como referência para auxiliar o diagnóstico clínico da SIS.

\section{ANÁLISE DA CONFIABILIDADE E REPRODUTIBILIDADE DA GONIOMETRIA EM RELAÇÃO À FOTOGRAMETRIA PARA A AVALIAÇÃO DE MEDIDAS NA MÃO}

\author{
Rosana Martins Ferreira de Carvalho \\ Orientador: Prof. Dr. Nilton Mazzer \\ Dissertação de Mestrado apresentada em 09/11/2010
}

A medida da amplitude de movimento (ADM) é definida como a liberdade de movimento da articulação que pode variar de acordo com diversas influências, permitindo aos profissionais fazerem uma análise da propedêutica, evolução do tratamento e prognóstico de modo quantitativo. O propósito do presente estudo foi avaliar a confiabilidade intra e interexaminadores assim como a reprodutibilidade da goniometria em relação à fotogrametria na mão, comparando os 
ângulos da abdução de polegar, flexão da articulação interfalangiana proximal do II dedo e flexão da articulação interfalangiana distal do V dedo. Para isto, participaram deste estudo trinta voluntários que foram divididos em três grupos de acordo com o grau de formação, um grupo formado por dez estudantes universitários da nona etapa do curso de Fisioterapia da FMRPUSP, outro por dez fisioterapeutas e o terceiro grupo formado por dez terapeutas da mão. Cada avaliador realizou as medidas no mesmo molde de mão de cera fornida com gesso, utilizando primeiramente o goniômetro e em seguida realizaram novamente as três medidas consecutivas de cada um dos ângulos com os dois softwares de fotogrametria separadamente, o Corel Draw e em seguida o ALCimagem, tendo a oportunidade de repetir quantas vezes julgassem necessário até que tivessem certeza do ângulo calculado. Para análise interxaminadores, os ângulos foram medidos por três grupos diferentes e os resultados comparados. Para análise intraexaminadores, os mesmos ângulos foram avaliados dentro de cada grupo separadamente em ocasiões diferentes. Para comparação dos resultados intra e interexaminadores, foi aplicado o coeficiente de correlação intraclasse. Os resultados revelaram que os grupos e os métodos propostos apresentam confiabilidade significativa interexaminadores no geral classificada como excelente (ICC geral=0,998 I.C. $95 \%$ 0,995 0,999), e ao analisarmos isoladamente cada ângulo em cada grupo, o grupo dos fisioterapeutas mostrou níveis não aceitáveis de reprodutibilidade $(\mathrm{ICC}<0,700)$ e que no grupo dos acadêmicos, dois ângulos, e no grupo dos terapeutas da mão, um ângulo, mostraram bons níveis da reprodutibilidade interexaminador. Na avaliação intra-examinadores, foi encontrado um excelente nível de confiabilidade ICC médio dentro de cada grupo $0,985 \mathrm{Dp}=0,024$, porém ao avaliar cada ângulo dentro de cada grupo isoladamente houve uma variação quanto a classificação de confiabilidade, e ao avaliar separadamente cada método, concluiu-se que não há diferença estatística entre os métodos, ou seja, excelente confiabiliadade intrainstrumentos. Comparando-se os resultados gerais de cada ângulo para cada método, independentemente do grupo, observou-se que para todos os ângulos houve diferença significativa entre os métodos. Portanto, tanto a goniometria como a fotogrametria apontam como métodos confiáveis para avaliação de medidas na mão. Porém, pela escassez de referências semelhantes, necessita-se de mais estudos aprofundados para definição de parâmetros de normalidade entre os métodos propostos nas articulações da mão.

\section{DESENVOLVIMENTO E APLICAÇÃO DE UM MODELO DE LUVA SENSORIAL}

\section{Raquel Metzker Mendes}

Orientador: Prof. Dr. Nilton Mazzer

Dissertação de Mestrado apresentada em 11/11/2010

A luva sensorial pode constituir uma ferramenta importante na recuperação da função sensorial da mão. Utilizada em uma fase precoce após lesões de nervos periféricos e associando as capacidades plásticas e de integração sensorial cerebral, a luva pode auxiliar na manutenção e/ou reorganização do mapa cortical de representação da mão no período póslesão. Os objetivos desse estudo foram o desenvolvimento e a construção de um modelo nacional de luva sensorial. O modelo foi testado em sujeitos com função sensorial normal da mão, por meio de um questionário de avaliação e do exame de ressonância magnética funcional (RMf). Para isso, a luva foi confeccionada por um técnico em eletrônica, utilizando-se luva de tecido; mini-microfones; um mini-amplificador e fones de ouvido. Foram selecionados 14 sujeitos, de ambos os sexos, 26,8 anos $( \pm 1,4)$ e que possuíam audição normal; sensibilidade, amplitude de movimento e força preservadas nos membros superiores. Os sujeitos foram divididos de forma aleatória e igualitária nos grupos experimental (GE), em que os sujeitos foram treinados a substituir o tato pela audição durante o uso da luva desenvolvida e o controle (GC), composto por sujeitos não-treinados. Durante o exame, os sujeitos receberam três tipos de estímulos: tátil (bastão revestido por velcro), tátil e auditivo associados e auditivo (textura de velcro passada sobre o microfone da luva). Após o exame, os sujeitos do GE responderam a um questionário de avaliação da luva e para comparação dos grupos foi aplicado o teste de Mann-Whitney. A construção do equipamento foi concluída em cerca de cinco meses e possui algumas diferenças em relação ao modelo proposto por Lundborg et al. (2007); a maior parte dos sujeitos do GE julgou o modelo de luva desenvolvido como confortável, de aspecto estético bom a ótimo e capaz de cumprir a função de possibilitar a substituição do tato pela audição na identificação de texturas. Além disso, os resultados obtidos a partir dos exames de RMf demonstraram que o estímulo auditivo foi capaz de ativar o GPC de todos os sujeitos e que não houve diferença estatística entre os grupos durante a ativação do GPC por quaisquer estímulos. Assim, pode-se concluir que: foi viável a confecção de um modelo brasileiro de luva sensorial; o estímulo auditivo proveniente do equipamento desenvolvido induziu a ativação do GPC nas condições descritas e que o treinamento dos sujeitos não influenciou de forma significativa a ativação do GPC entre os grupos, durante a aplicação dos estímulos. 


\title{
ANÁLISE MECÂNICA DAS VARIÁVEIS RELACIONADAS COM A FIXAÇÃO DO PARAFUSO PEDICULAR
}

\author{
Rodrigo Cesar Rosa \\ Orientador: Prof. Dr. Helton Luiz Antonio Defino \\ Tese de Doutorado apresentada em 23/11/2010
}

O objetivo do estudo foi avaliar a influência das variáveis relacionadas com a fixação dos parafusos pediculares, utilizando vértebras de bovino. No estudo foram utilizados trinta bovinos do sexo masculino, da raça holandesa, com idade de seis a oito semanas e massa corpórea média de $58 \pm 9 \mathrm{Kg}$. Os animais com esta idade são chamados de vitelo. Os parafusos analisados possuíam dois formatos de rosca, cilíndrica e com alma (parte interna) cônica, de titânio. Os testes mecânicos dos implantes foram realizados utilizando trinta segmentos toracolombares, correspondendo à última vértebra torácica (T13 ou T14) e as cinco primeiras vértebras lombares (L1 - L5). Os segmentos vertebrais foram submetidos análise dual $x$-ray absorptiometry, apresentando densidade mineral óssea média de $0,24 \pm 0,01 \mathrm{~g} / \mathrm{cm}^{2}$. O preparo do orifício piloto foi realizado utilizando brocas e sondas (ponta cortante e ponta romba) com 3,0 $\mathrm{mm}$ e 3,8 $\mathrm{mm}$ de diâmetro, sendo que o último diâmetro corresponde ao valor recomendado pelo fabricante. O torque de inserção dos parafusos foi mensurado por meio de torquímetro com capacidade de 10Nm e Software MK versão.1.0.0.6/2004, sendo adotado o maior valor de torque obtido durante a inserção do implante. Os ensaios mecânicos de arrancamento dos parafusos foram realizados utilizando máquina universal de ensaio Emicâ e Software Tesc 3.13 para análise dos resultados, utilizando célula de carga com capacidade de $20000 \mathrm{~N}$ e velocidade de aplicação de força de $2 \mathrm{~mm} / \mathrm{min}$. Os resultados mostraram que os parafusos fixados no pedículo vertebral apresentaram maiores valores de toque de inserção e força de arrancamento, que os observados no corpo vertebral. Os maiores valores de torque de inserção foram observados nos orifícios piloto de $3,8 \mathrm{~mm}$ confeccionados com sonda pontiaguda e cortante no pedículo vertebral. O preparo do orifício piloto com sonda, no corpo vertebral, influenciou na resistência dos parafusos, sendo observados maiores valores de força de arrancamento nos orifícios piloto confeccionados com sonda cortante, em ambos diâmetros de perfuração. O macheamento do orifício piloto reduziu o torque de inserção e a força de arrancamento dos parafusos com alma cônica. O diâmetro dos orifícios piloto utilizados não apresentou influência em nenhuma das variáveis estudadas.

\section{AVALIAÇÃO EXPERIMENTAL DA RESPOSTA DA CARTILAGEM ARTICULAR EM FALHA OSTEOCONDRAL DE JOELHO TRATADO COM GEL DE PLASMA RICO EM PLAQUETAS}

\author{
Márcio de Oliveira Carneiro \\ Orientador: Prof. Dr. Cláudio Henrique Barbieri \\ Dissertação de Mestrado apresentada em 24/11/2010
}

O objetivo deste estudo foi avaliar experimentalmente a resposta da cartilagem articular em falha osteocondral de joelho de carneiros tratados com gel de plasma rico em plaquetas (PRP). Em 10 carneiros adultos fêmeas com peso entre 30 e $50 \mathrm{~kg}$ foram produzidas falhas nas cartilagens articular no sulco troclear dos joelhos. No joelho direito (grupo experimental), as falhas foram preenchidas com gel de PRP, enquanto no joelho esquerdo as falhas foram deixadas vazias (grupo controle). O PRP foi produzido por meio de dupla centrifugação do sangue colhido no período que antecedeu o procedimento cirúrgico. Todos os animais foram mortos após 12 semanas do ato cirúrgico. Na análise macroscópica do tecido formado, foram avaliados parâmetros como adesão intra-articular, restauração da superfície articular, erosão da cartilagem e aparência da cartilagem. Na análise microscópica, foram analisados: integridade do tecido regenerado, nível da superfície da lesão em relação à cartilagem adjacente e união do tecido regenerado com a cartilagem adjacente, tipo de tecido regenerado e regularidade da superfície. A somatória dos pontos avaliados nas análises macroscópica e microscópica entre os joelhos esquerdo e direito foi comparada utilizando o teste de Wilcoxon pareado. Os resultados da comparação entre os joelhos esquerdo e direito mostraram que não houve diferença significativa quanto ao aspecto macroscópico da cartilagem articular e da lesão. Microscopicamente, em nenhum dos joelhos estudados foi observado reparo do defeito com cartilagem articular normal. Em três joelhos esquerdos, o tecido formado era constituído de cartilagem pobremente diferenciada; nos sete restantes, o tecido era francamente fibroso. Já no joelho direito, ocorreu o inverso, com cartilagem pobremente diferenciada em sete e tecido francamente fibroso em três. Os dados comparativos dos parâmetros dos joelhos direito e esquerdo mostraram diferença significativa para a somatória dos pontos avaliados para ambos ( $\mathrm{p}=0,0313$ ). Concluindo, o PRP, na forma como preparado na presente investigação, possui propriedades reparativas da cartilagem articular do joelho de carneiros, estimulando a formação de um tecido com características fibro-cartilaginosas. 


\title{
ESTUDO ERGONÔMICO DE PILOTOS DO ESQUADRÃO DE DEMONSTRAÇÃO AÉREA BRASILEIRO
}

\author{
Suraya Gomes Novais Shimano \\ Orientadora: Profa. Dra. Marisa de Cássia Registro Fonseca \\ Tese de Doutorado apresentada em 15/12/2010
}

O Esquadrão de Demonstração Aérea (EDA) é o grupo mais popular da Força Aérea Brasileira. Seus pilotos formam um grupo seleto que possui condições laborais peculiares. Por isso há grande interesse em conhecer esta rotina de trabalho. O presente estudo objetivou avaliar as condições ergonômicas de trabalho dos pilotos do EDA. Foi utilizada metodologia multivariada: 1) análise antropométrica dos pilotos e comparação com a geometria da cabine; 2) análise de conteúdo das respostas a entrevista sobre o nível de satisfação dos pilotos com as condições de trabalho e percepção de sobrecargas físicas; 3 ) análise eletromiográfica das solicitações musculares em simulação de voo. O sinal mioelétrico foi captado por eletrodos bipolares ativos conectados a um eletromiógrafo EMG 810C (EMG System). A impedância de entrada foi de $10 \mathrm{M} \Omega$ e amplificação de sinal de 100x no condicionador de sinais e de 20x no eletrodo. A frequência de amostragem por canal foi de $1 \mathrm{KHz}$, com Razão de Rejeição de Modo Comum de 120 dB. A normalização do sinal foi feita pela CIVM de cada músculo. A análise foi feita em 2 tempos do movimento de giro lateral do manche, posição inicial (PI) e posição final (PF) e em dois níveis de recrutamento, contração normal (CN) e contração vigorosa (CV). Os resultados do estudo demonstraram que a análise antropométrica apresentou ótima compatibilidade piloto-cabine da aeronave. Já a análise do conteúdo evidenciou percepção pelos pilotos de muito desconforto relacionado ao calor dentro da aeronave, à sobrecarga imposta pela força $+\mathrm{Gz}$, ao assento ejetável (confirmado pelo dimensionamento não ergonômico) e relacionaram maior sintomatologia ao período inicial de treinos. Também confirmou o excelente relacionamento interpessoal e a grande satisfação dos pilotos com o trabalho. A eletromiografia demonstrou níveis baixos a moderados de ativação dos músculos do ombro durante a CN (de 6\% para bíceps na PI a 41,8\% para trapézio fibras médias na PF). Mas apresentou níveis altos de recrutamento de todos os músculos, exceto do bíceps, durante a contração vigorosa (de 45,3\% para tríceps na PF a 107,8\% para trapézio fibras superiores na PI). A grande solicitação do músculo deltóide fibras posteriores (+90\% durante as $\mathrm{CV}$ ) infere recrutamento a níveis muito altos dos músculos do manguito rotador como os músculos infrespinhoso e redondo menor e pode explicar a sintomatologia dolorosa dos pilotos no ombro direito durante o período inical de treinos. A análise conjunta destes resultados propicia inferir que, de modo geral, há boas condições ergonômicas de trabalho dos pilotos e que medidas intervencionistas relativamente simples como adequação dos assentos das aeronaves, inclusão de pausas maiores nos treinos iniciais de voo e preparo físico dos pilotos durante o período inicial de treinamento parecem suficientes para minimizar de forma muito satisfatória os sintomas de desconforto e dor.

\section{CORRELAÇÃO ENTRE OS ACHADOS DE IMAGEM DE ARTROSSONOGRAFIA E ARTRORRESSONÂN- CIA EM PACIENTES COM INSTABILIDADE ANTERIOR DO OMBRO- 90 PGS}

\author{
Marcelo Novelino Simão \\ Orientador: Prof. Dr. Cláudio Henrique Barbieri \\ Tese de Doutorado apresentada em 17/12/2010
}

A articulação glenumeral é considerada a mais instável do corpo humano. As lesões relacionadas a luxação traumática anterior do ombro incluem a deformidade de Hill Sachs e as lesões de Bankart cartilaginoso ou avulsão lábio-ligamentar anteroinferior e de Bankart óssea. A artrorressonância é considerada o melhor método de imagem para a avaliação destas lesões. A ultrassonografia é reconhecidamente um método muito eficaz para a avaliação de tecidos moles na região do ombro, especialmente com relação aos tendões do manguito rotador, porém seu desempenho na avaliação das alterações relacionadas às luxações traumáticas do ombro é menos estudado e não está bem estabelecido. O objetivo deste trabalho é determinar a capacidade diagnóstica da ultrassonografia em pacientes com história prévia de luxação traumática, utilizando posicionamentos e critérios já relatados na literatura, comparar esses achados com os obtidos em exames de artrorressonância e em cirurgias, e avaliar sua reprodutibilidade, com cálculo de concordâncias intra e interobservadores. Prospectivamente, cinquenta e seis pacientes submetidos a exames de artrorressonância de ombro, por solicitação clínica, foram também avaliados por ultrassonografia após a injeção do contraste intra-articular. Todos os exames foram realizados pelo mesmo médico radiologista, sendo este denominado o operador dos exames, com a finalidade de detecção ou não das 
lesões de Hill Sachs, Bankart cartilaginoso e ósseo. Retrospectivamente dois outros radiologistas, denominados de examinadores, avaliaram as imagens obtidas durante os exames. A análise estatística incluiu os cálculos da sensibilidade, especificidade e as concordâncias intra e interobservadores, utilizando o teste de Kappa. A concordância interobservadores na artrorressonância variou de 0,54 a 0,70, sendo melhor para Bankart ósseo, na ultrassonografia variou de 0,19 a 0,40, sendo melhor para lesão de Hill Sachs. A concordância intraobservador para o examinador 1 variou de 0,20 a 0,25, sendo melhor para lesão de Hill Sachs e para o examinador 2 variou de 0,44 a 0,68, sendo melhor para lesão de Bankart óssea. Os resultados de sensibilidade para o operador, na artrorressonância, variaram de $90 \%$ a $100 \%$ e para os examinadores 1 e 2 variaram de $80 \%$ a $100 \%$. Na ultrassonografia os resultados de sensibilidade para o operador variaram de $90 \%$ a $100 \%$ e para os examinadores 1 e 2 variaram de $20 \%$ a $89 \%$. Os resultados de especificidade para o operador, na artrorressonância, variaram de $60 \%$ a $100 \%$ e para os examinadores 1 e 2 variaram de $50 \%$ a 100 . Na ultrassonografia os resultados de especificidade para o operador variaram de $60 \%$ a $86 \%$ e para os examinadores 1 e 2 variaram de $25 \%$ a $90 \%$. Estes resultados demonstram que: 1) exames de artrorressonância e de ultrassonografia realizados por um operador treinado têm alta sensibilidade e especificidade para demonstrar as alterações ósseas e de partes moles relacionadas à luxação traumática do ombro; 2) a artrorressonância obteve melhores resultados e foi mais reprodutível que a ultrassonografia, quando as imagens obtidas nos exames foram avaliados pelos examinadores, especialmente com relação às lesões de Bankart cartilaginoso e ósseo.

\title{
Saúde da Criança e do Adolescente
}

\section{ESTUDO DO DESENVOLVIMENTO NEUROCOMPORTAMENTAL INICIAL DE NEONATOS PRÉ- TERMO PEQUENOS E ADEQUADOS PARA A IDADE GESTACIONAL}

\author{
Inalu Barbosa da Silva \\ Orientador: Prof. Dr. José Simon Camelo Júnior \\ Dissertação de Mestrado apresentada em 11/11/2010
}

O avanço na área de atendimento intensivo neonatal contribuiu para um aumento na sobrevivência de recémnascidos pré-termo, no entanto, estes estão expostos a riscos de alterações no seu desenvolvimento motor, comportamental e cognitivo. O estudo visou principalmente a comparar o desenvolvimento neurocomportamental inicial de recémnascidos pré-termo com idade pós-concepcional entre 32 e 37 semanas, em grupos diferenciados pela adequação do peso para idade gestacional. Os objetivos específicos foram: a) comparar este desenvolvimento entre os grupos, utilizando escores e classificação por desvio-padrão da Avaliação Neurocomportamental do Bebê Pré-Termo (NAPI); b) comparar o desempenho neurocomportamental da amostra de estudo com a amostra original de padronização do instrumento e com a amostra de um estudo realizado em Goiânia. Foram avaliados 55 bebês pré-termo, sendo 32 pequenos para a idade gestacional (PIG) e 23 adequados (AIG), de ambos os sexos, estáveis clinicamente, internados na Unidade de Cuidados Intermediários do Hospital das Clínicas da Faculdade de Medicina de Ribeirão Preto, no período de 09 de fevereiro a 09 de dezembro de 2009. Os seguintes instrumentos foram utilizados: NAPI, roteiro de anamnese, Critério de Classificação Econômica Brasil da Associação Brasileira de Empresas de Pesquisa e prontuário médico. O procedimento de avaliação foi filmado. Primeiramente os dados foram analisados por meio de estatística descritiva para toda a amostra e também para os grupos. As variáveis categóricas foram vistas em termos de frequência, prevalência ou porcentagem, e as variáveis numéricas, em termos de média, desvio-padrão, mediana e valores máximo e mínimo. Para comparar os grupos quanto às variáveis de caracterização da amostra e quanto aos escores do NAPI por domínio, foi realizado o teste t de Student ou teste U de MannWhitney para as variáveis contínuas, a depender da normalidade dos dados. Enquanto para as variáveis categóricas de caracterização foi utilizado o teste Exato de Fisher, bem como para analisar os grupos, considerando a classificação por desvios-padrão. Procedeu-se à comparação entre os resultados do NAPI obtidos na amostra total do estudo, nas idades pós-concepcionais de 35 e 36 semanas, com os resultados da amostra original de padronização do instrumento, assim como com os resultados de uma amostra brasileira, por meio do programa InStat. Foi considerado o valor de p menor ou igual a 0,05 para todos os testes realizados e calculados intervalos de confiança de $95 \%$. Os resultados mostraram que não houve diferença entre os grupos PIG e AIG em nenhum dos domínios, considerando o escore e o desvio-padrão no NAPI. A amostra total deste estudo, quando comparada com uma amostra de Goiânia, obteve melhor escore no Ângulo Poplíteo. 
Quando comparada com a amostra de padronização do instrumento, a amostra do estudo mostrou piores escores nos domínios Sinal de Cachecol, Desenvolvimento Motor e Vigor, Choro e Percentual Adormecido. Porém, demonstrou melhores escores nos domínios Ângulo Poplíteo e Alerta e Orientação. Os resultados obtidos remetem à importância da detecção dos fatores de risco em relação ao desenvolvimento neurocomportamental inicial dos bebês pré- termo para o estabelecimento de um programa de intervenção preventiva, a fim de evitar problemas no desenvolvimento futuro.

\section{ESTRESSE OXIDATIVO EM NEONATOS E LACTENTES SUBMETIDOS À CIRURGIA CARDÍACA COM CIRCULAÇÃO EXTRACORPÓREA}

\section{Paulo Henrique Manso}

Orientadora: Prof ${ }^{\mathrm{a}}$ Dr $^{\mathrm{a}}$ Ana Paula C. P. Carlotti.

Tese de Doutorado apresentada em 26/11/2010

Objetivo: Investigar se as concentrações séricas dos marcadores de estresse oxidativo, substâncias reativas ao ácido tiobarbitúrico (TBARS) e carbonil, estão associadas com a incidência de síndrome do baixo débito cardíaco (SBDC) em crianças após cirurgia cardíaca com circulação extracorpórea (CEC).

Desenho do estudo: Estudo prospectivo longitudinal observacional do tipo coorte, realizado em Unidade de Terapia Intensiva Pediátrica (UTIP) de hospital terciário universitário.

Pacientes: Cinquenta e cinco neonatos e lactentes (idade mediana de 109 dias, variando de 2 a 611 dias).

Intervenção: Nenhuma.

Resultados principais: Pacientes que apresentaram SBDC após cirurgia cardíaca (grupo 1, n=36) foram mais jovens (58 [2-571] vs. 189 [37-611] dias, $\mathrm{p}=0,004)$, mais frequentemente cianóticas (66\% vs. 15\%, $\mathrm{p}=0,001)$, de menor peso corporal $(3,5$ [2,1-9,0] vs. 5,0 [2,2-8,5] kg, p=0,011), com escore PRISM maior (10 [2-19] vs. 3,5 [2-16], p=0,009) e maior escore RACHS1 (3 [2-6] vs. 2 [1-4], p=0,008), e tiveram maior tempo de CEC (122 [35-245] vs. 70 [35-170] minutes, p=0,048). Após a cirurgia, os pacientes que apresentaram SBDC tiveram mais complicações e maior tempo de hospitalização (10 [1-88] vs. 3 [1-15] dias, $p=0,006)$. As concentrações séricas de TBARS aumentaram significativamente após a cirurgia apenas no grupo com SBDC, e foram significativamente maiores que no grupo sem baixo débito cardíaco com 4 horas de pós-operatório (PO) $(\mathrm{p}=0,03)$. Não houve diferenças na concentração sérica dos níveis de carbonil entre os grupos em nenhum momento, e as variações ao longo do tempo não foram significativas. A regressão logística multivariável evidenciou que as concentrações séricas de TBARS 4hs PO (OR 27,4 (1,4-535), p=0,029) se associaram com a SBDC pós-operatória, independentemente de fatores de confusão: idade (OR 7,5 (0,5-114), p=0,145), tempo de CEC (OR 7,4 (0,6-85), p=0,105) e escore inotrópico 4h PO(OR 103,6 (6,1-1739), p=0,001).

Conclusão: O marcador de estresse oxidativo TBARS, medido 4hs PO, associou-se independentemente à SBDC no pós-operatório de cirurgia cardíaca com CEC em neonatos e lactentes, a despeito da idade, da duração da CEC e do escore inotrópico.

\section{ESTUDO DO GENE DO RECEPTOR-3 DA MELANOCORTINA EM CRIANÇAS E ADOLESCENTES OBESOS}

\section{Cristina Costa de Barros Malerba}

Orientadora: Profa. Dra. Heloisa Bettiol

Dissertação de Mestrado apresentada em 08/12/2010

Introdução: O sistema melanocortina central é a via neuronal que regula a ingestão alimentar e homeostase energética por meio da ligação do hormônio estimulante do melanócito á a receptores específicos. Camundongos deficientes do receptor-3 do hormônio estimulador do melanócito-á (MC3R) tem aumento do depósito de gordura, redução da massa muscular e maior eficiência alimentar do que os camundongos não deficientes, apesar de serem hipofágicos e manterem taxas metabólicas normais. Na literatura os estudos apresentam resultados divergentes, alguns estudos em humanos descreveram mutações ou polimorfismos no gene do $M C 3 R$ associados à obesidade e outros não observaram essas associações. Objetivo: Identificar a presença de mutações e/ou polimorfismos no gene do $M C 3 R$ em crianças e adolescen- 
tes obesos. Comparar a frequência das mutações e/ou polimorfismos encontrados nas crianças obesas com a frequência dessas variações genotípicas em indivíduos de peso normal. Comparar os dados clínicos, antropométricos e bioquímicos dos obesos com e sem mutação/polimorfismo.

Material e Métodos: Participaram do estudo 67 crianças e adolescentes do Ambulatório de Obesidade Infantil do Hospital das Clínicas da Faculdade de Medicina de Ribeirão Preto- USP que tenham obesidade grave iniciada antes dos 8 anos de idade. Foram feitas PCRs (Polimerase Chain Reaction) com primers para amplificar a cadeia de DNA e sequenciamento do segmento de interesse na busca de variações no gene do $M C 3 R$. O sequenciamento obtido foi comparado com o Gene Bank. Foram realizados também exames de bioimpedância para estimar a composição corporal e dosagens de colesterol e frações, glicemia e insulina de jejum. A frequência das variações genotípicas foi comparada com um grupo de 71 indivíduos com peso normal aplicando-se o teste exato de Fisher. Os valores dos exames sanguíneos e composição corporal foram comparados entre obesos com e sem variações genotípicas, utilizando-se o teste não paramétrico de Wilcoxon. O nível de significância adotado foi de $5 \%$.

Resultados: Foram encontradas dois polimorfismos no gene do $M C 3 R$, c. $17 \mathrm{C}>\mathrm{A}$ e c. $241 \mathrm{G}>\mathrm{A}$ que não estavam associadas à obesidade. Nenhuma variante rara foi encontrada. Os indivíduos obesos com estes polimorfismos não apresentaram diferenças no escore z de IMC, relação peso/estatura, circunferência da cintura, cor da pele, impedância bioelétrica, glicemia, insulina plasmática de jejum, HOMA-IR e colesterol total e frações.

Conclusão: Este estudo não fornece evidências para um efeito das variantes da região codificadora do gene do $M C 3 R$ na obesidade grave de início precoce deste grupo de 67 crianças e adolescentes.

\title{
ANGIOEDEMA HEREDITÁRIO: ESTUDO CLÍNICO E GENÉTICO DE UMA FAMÍLIA BRASILEIRA
}

\author{
Maria Fernanda Ferraro \\ Orientadora: Prof. Dra. Luisa Karla de Paula Arruda \\ Tese de Doutorado apresentada em 10/12/2010
}

O angioedema hereditário (AEH) é uma doença autossômica dominante caracterizada por episódios de edema subcutâneo e/ou submucoso localizado e não pruriginoso. É causado pela deficiência de inibidor de C1 (C1-INH) funcional, o que leva à inibição insuficiente das cascatas plasmáticas formadoras de bradicinina. Aumento nos níveis de bradicinina é evento- chave na patogênese dos episódios de angioedema. Mais de 200 mutações foram descritas no gene que codifica o C1-INH (SERPING1). Os objetivos deste estudo foram analisar as características clínicas de uma numerosa família com caso-índice de AEH e investigar o defeito genético causador da doença nessa família. O heredograma da família foi construído com 275 indivíduos relacionados distribuídos em 5 gerações. Desses, 165 foram entrevistados e tiveram amostras de sangue coletadas para análise genética. Os indivíduos que referiam história de episódios recorrentes de angioedema e/ou crises de dor abdominal foram avaliados para $\mathrm{AEH}$, incluindo dosagens de $\mathrm{C} 4 \mathrm{e} \mathrm{C} 1$-INH. Identificamos uma nova mutação no gene SERPING1, c.351 delC - deleção de um nucleotídeo citosina no exon 3 - que resulta em frameshift e stop codon prematuro. Um modelo molecular da proteína truncada hipotética foi gerado permitindo-nos concluir que, se transcrita, essa proteína não possui atividade biológica. Vinte e oito membros da família preencheram critérios diagnósticos de AEH e todos eles apresentaram a mutação c. $351 \mathrm{delC}$. Houve ampla variabilidade na apresentação clínica do AEH nesses pacientes. Os outros 137 indivíduos avaliados sem AEH não apresentaram a mutação c.351delC. Esta é a família com maior número de indivíduos com AEH já descrita, e este estudo constitui-se na primeira análise molecular de AEH descrita na América Latina. O presente estudo fornece evidência definitiva da relação causal entre a nova mutação genética c.351delC e o desenvolvimento de $\mathrm{AEH}$ em pacientes de uma família brasileira.

\section{AVALIAÇÃO DA ESTATURA FINAL EM CRIANÇAS COM BAIXA ESTATURA}

\author{
Karla Cristina Malta Costa \\ Orientador: Prof. Dr. Luiz Antônio Del Ciampo \\ Dissertação de Mestrado apresentada em 14/12/2010
}

Introdução: Pacientes com baixa estatura variante normal do crescimento têm padrões evolutivos peculiares. É difícil definir com exatidão quando a estatura final será atingida, visto que os métodos de previsão baseiam-se em parâmetros de difícil quantificação, como a idade óssea. 
Objetivos: Avaliar a estatura final utilizando dois métodos de previsão da estatura final de pacientes com diagnóstico de variantes normais da baixa estatura, atendidas no Ambulatório de Problemas de Crescimento e Desenvolvimento do Hospital das Clínicas da Faculdade de Medicina de Ribeirão Preto-USP.

Métodos Foram revisados 814 prontuários resultando 33 sujeitos que participaram do estudo e analisadas radiografias de 21 sujeitos utilizando-se o método de Greulich Pyle para predição de altura final pelo método de Bayley-Pinneau e um software específico para predição pelo TW3, após leitura da idade óssea. Realizou-se descrição das variáveis e foi calculado o coeficiente de correlação de Spearman para correlacionar a estatura final, e o canal familiar e o coeficiente de concordância de St. Laurent para avaliar a concordância entre a estatura final e os métodos de previsão.

Resultados: $81,5 \%$ apresentam diagnóstico de baixa estatura, sendo $62 \%$ do sexo masculino. $53 \%$ com baixa estatura variante da normalidade. Na estatura final, 87,9\% permanecem com baixa estatura, 90,9\% dentro do canal familiar. Observou-se correlação positiva muito forte ( $\mathrm{Cs}=0,77$; p-valor $<0,01)$ entre a média parental e a altura final. O método de Bayley-Pineau apresentou coeficiente de concordância de 0,47 (IC 95\%: 0,34; 0,57), o de TW3, 0,58 (IC 95\%: 0,41; 0,75) como preditores de estatura final.

Conclusões: A correlação positiva forte demonstra a influência significativa da altura dos pais na estatura final. Nenhum dos dois métodos apresentou boa concordância ao serem utilizados como preditores de estatura final, pois os valores das alturas foram superestimados principalmente pelo método de Bayley-Pineau.

\title{
Saúde Mental
}

\section{SINTOMAS OBSESSIVO-COMPULSIVOS NAS DEMÊNCIAS}

\author{
Marina Ceres Silva Pena \\ Orientador: Prof. Dr. Francisco de Assis Carvalho do Vale \\ Dissertação de Mestrado apresentada em 01/10/2010
}

Demências são síndromes caracterizadas por um declínio cognitivo, usualmente acompanhado por sintomas comportamentais e psicológicos das demências (SCPD), destacando-se por sua alta prevalência, e alto custo socioeconômico. Da mesma maneira como ocorre com outros SCPD, é possível que os sintomas obsessivo-compulsivos (SOC) nas demências também levem a um maior desgaste do cuidador, maior morbidade, aumento do risco de institucionalização precoce do paciente e também aumento do custo. O objetivo desse estudo foi verificar a ocorrência de SOC em pacientes com demência, assim como observar as consequências dessa ocorrência no paciente e em seu cuidador em termos de sintomas psicológicos e comportamentais, incluindo ansiosos, depressivos, de carga e de qualidade de vida. Para tal foi realizado um estudo transversal analítico de uma casuística de um ambulatório terciário composta por 84 pacientes com demência e 75 cuidadores. Os grupos demenciais incluíram a doença de Alzheimer (DA), demência vascular tipo Binswanger (DV), demência frontotemporal (DFT) e demências com sinucleinopatias (demência com corpos de Lewy ou demência da doença de Parkinson - DSin). Os dados foram coletados a partir da aplicação do questionário de informações pessoais do paciente e de seu cuidador; escala Yale-Brown de sintomas obsessivo-compulsivos (YBOCS), escala global de 15 pontos de obsessões e compulsões do Instituto Nacional de Saúde Mental dos Estados Unidos da América (NIMH-OC), inventário neuropsiquiátrico (INP), escala de qualidade de vida (EQV), inventário de sobrecarga de Zarit (ISZ), escala de ansiedade e depressão (HAD). Dos 84 pacientes incluídos no estudo, $55(65,48 \%)$ apresentavam algum SOC segundo o YBOCS. A maioria caracterizada com sintomas leves segundo a NIMH-OC. Setenta e dois $(85,71 \%)$ faziam uso de algum psicotrópico. Cinquenta e sete $(67,86 \%)$ possuíam alguma comorbidade. Setenta e cinco $(89,29 \%)$ possuíam algum SCPD não-SOC segundo o INP. Dados referentes ao cuidadores apontaram escores medianos de qualidade de vida e carga. A maioria dos cuidadores apresentou sintomas ansiosos e depressivos leves a moderados. Para comparação das médias foi utilizado o teste de correlação de Spearman, onde valores de $\mathrm{p}<0.05$ foram considerados significantes. Os resultados sugerem que SOC são frequentes nos quadros demenciais, apesar de subnotificados; a primeira parte do YBOCS mostrou-se aplicável na avaliação de pacientes com demência, porém com algumas adaptações. O uso de psicotrópicos pareceu não ter evitado a ocorrência, no entanto parece ter interferido positivamente nas consequências dele sobre o cuidador. Inibidores de acetilcolinesterase parecem ter o mesmo efeito, mesmo não sendo esta sua indicação primária. 


\title{
ALÍVIO DE DOR EM NEONATOS PRÉ-TERMO: AVALIAÇÃO DA EFICÁCIA DO USO CONTINUADO DE SACAROSE
}

\author{
Claudia Maria Gaspardo \\ Orientadora: Profa. Dra. Maria Beatriz Martins Linhares \\ Tese de Doutorado apresentada em 09/11/2010
}

A trajetória de desenvolvimento do neonato pré-termo se inicia no contexto da Unidade de Terapia Intensiva Neonatal, permeado pela presença contínua de diversos estímulos dolorosos. As experiências iniciais e repetidas de dor podem ter efeito em longo prazo para os neonatos vulneráveis. AAcademia Americana de Pediatria e a Sociedade Pediátrica Canadense recomendam o uso da solução de sacarose como intervenção não-farmacológica para alívio de dor em neonatos, entretanto, a eficácia e segurança do uso continuado da sacarose necessitam de investigação. O presente estudo randomizado controlado duplo-cego teve por objetivos avaliar a eficácia da administração via oral da solução de sacarose a $25 \%$, em esquema de doses repetidas no alívio da dor em neonatos pré-termo e avaliar os possíveis efeitos colaterais advindos do uso continuado da sacarose para os neonatos. Trinta e três neonatos pré-termo com muito baixo peso ao nascer foram distribuídos em dois grupos: Grupo Sacarose $(n=17)$ e Grupo Água $(n=16)$. Os neonatos foram avaliados durante quatro dias consecutivos, durante procedimento de punção para coleta de sangue. Cada avaliação foi dividida em cinco fases: Linha de Base, Preparação para Punção (antissepsia), Punção, Recuperação com Manuseio (curativo) e Recuperação sem Manuseio. O indicador de dor foi avaliado pela atividade facial, mensurada pelo Neonatal Facial Coding System (NFCS). O nível de ativação dos neonatos foi mensurado pelo estado de vigília e sono e pela frequência cardíaca. Na primeira avaliação, os neonatos de ambos os grupos não receberam nenhuma substância antes do procedimento doloroso. Nos três dias seguintes, o Grupo Sacarose recebeu $0,5 \mathrm{ml} / \mathrm{kg}$ de sacarose oral e o Grupo Água recebeu água estéril, dois minutos antes de cada procedimento doloroso. Foram obtidos dados de evolução clínica dos neonatos nos prontuários médicos. Os resultados encontrados revelaram que no primeiro dia de avaliação os neonatos de ambos os grupos anteciparam a reação ao estímulo doloroso de punção, apresentando elevação significativa do escore do NFCS, do estado de vigília e sono e da frequência cardíaca, já na antissepsia, sendo que durante a recuperação a frequência cardíaca continuou elevada em comparação à fase de Linha de Base. A partir do segundo dia de avaliação, o Grupo Sacarose apresentou menores escores do NFCS e do estado de vigília e sono, durante o procedimento, em comparação ao Grupo Água. O indicador fisiológico de frequência cardíaca não apresentou diferença significativa entre os grupos, entretanto, a sacarose reduziu o tempo necessário para o neonato se recuperar e atingir a estabilidade fisiológica após passar pelo procedimento doloroso de punção. Não houve diferença significativa na evolução clinica dos neonatos de ambos os grupos, o que demonstra que a sacarose não causou efeitos colaterais em curto prazo aos neonatos. Conclui-se que a dose de $0,5 \mathrm{ml} / \mathrm{kg}$ de solução de sacarose a $25 \%$ administrada em esquema de doses repetidas foi eficaz para o alívio da dor em neonatos prétermo e não trouxe efeitos colaterais imediatos para o estado de saúde dos neonatos.

\section{ESPECTRO DO TRANSTORNO DE ANSIEDADE SOCIAL: ESTUDO DE SUAS COMORBIDADES PSIQUIÁTRICAS E ASSOCIAÇÃO COM O PROLAPSO DE VALVA MITRAL}

\author{
Alaor Santos Filho \\ Orientador: Prof. Dr. José Alexandre de Souza Crippa \\ Tese de Doutorado apresentada em 16/11/2010
}

Introdução: O transtorno de ansiedade social (TAS) é uma condição que pode ser muito incapacitante, com considerável sofrimento subjetivo, alta prevalência de comorbidades psiquiátricas e impacto negativo no funcionamento psicossocial. Entretanto, existem poucos dados na literatura sobre a possível extensão deste comprometimento nos indivíduos com sinais e sintomas subclínicos do TAS. Além disso, a discussão sobre a associação entre o prolapso de valva mitral (PVM) e os transtornos de ansiedade, particularmente com o transtorno de pânico e o TAS, existe já há cerca de três décadas, mas os resultados publicados não são suficientes para definitivamente estabelecer ou excluir a associação entre essas condições, com prevalências variando de 0 a 57\%. Método: O delineamento metodológico envolveu duas etapas. $\mathrm{Na}$ primeira, as comorbidades psiquiátricas e o comprometimento no funcionamento psicossocial foram avaliados em 355 estudantes universitários que haviam sido diagnosticados previamente como TAS ( $\mathrm{n}=141$ ), TAS subclínico (n=92) ou 
controles ( $\mathrm{n}=122)$. Na segunda etapa, um total de 232 voluntários diagnosticados como transtorno de pânico ( $\mathrm{n}=41)$, TAS $(n=89)$ ou controles $(n=102)$ foram avaliados em ecocardiografia quanto ao PVM. Os exames foram realizados por dois cardiologistas que estavam "cegos" em relação ao diagnóstico psiquiátrico dos participantes. Foram obtidas medidas utilizando os critérios atuais e antigos para o diagnóstico de PVM, para permitir a comparação e generalização dos resultados. Resultados: A taxa de comorbidade com outros transtornos psiquiátricos foi de 71,6\% no grupo TAS e de 50\% nos sujeitos com TAS subclínico, ambos significativamente maiores que os controles (28,7\%). A presença de comorbidades foi progressivamente maior de acordo com o subtipo e a gravidade do TAS. Quanto ao funcionamento psicossocial o grupo TAS apresentou maior comprometimento que os outros dois grupos em todos os domínios avaliados, e os sujeitos com TAS subclínico apresentaram valores intermediários. Na segunda etapa, os resultados demonstraram que não há diferenças estatísticas entre os grupos quanto à prevalência de PVM, seja pelos critérios ecocardiográficos atuais para o diagnóstico de PVM (visão longitudinal paraesternal: pânico=2,4\%, TAS $=4,5 \%$, controles $=1,0 \%$ ) ou pelos critérios antigos (visão apical de 4-câmaras: pânico $=2,4 \%$, TAS $=4,5 \%$, controles=10,8\%; modo-M: pânico=2,4\%, TAS=6,7\%, controles $=4,9 \%$ ). Também não houve diferenças significativas em relação a outras características morfológicas, como presença de regurgitação mitral, espessamento valvar ou presença de alongamento de cordoalhas. Conclusões: A prevalência de comorbidades psiquiátricas e o comprometimento no funcionamento psicossocial aumentam progressivamente ao longo do espectro de ansiedade social. O fato de o TAS subclínico apresentar considerável incapacidade e sofrimento em comparação com sujeitos controles justifica uma revisão na validade desses critérios diagnósticos. Por outro lado, não houve associação entre o transtorno de pânico ou o TAS com o PVM em nossos resultados, independente dos critérios diagnósticos utilizados, com prevalências compatíveis com a esperada na população geral. Dessa forma, é preciso desmistificar a relação entre essa alteração cardíaca e o transtorno de pânico e o TAS, pelas repercussões que pode ter para o paciente e em seu tratamento psiquiátrico. 